Historic, Archive Document

Do not assume content reflects current scientific knowledge, policies, or practices. 



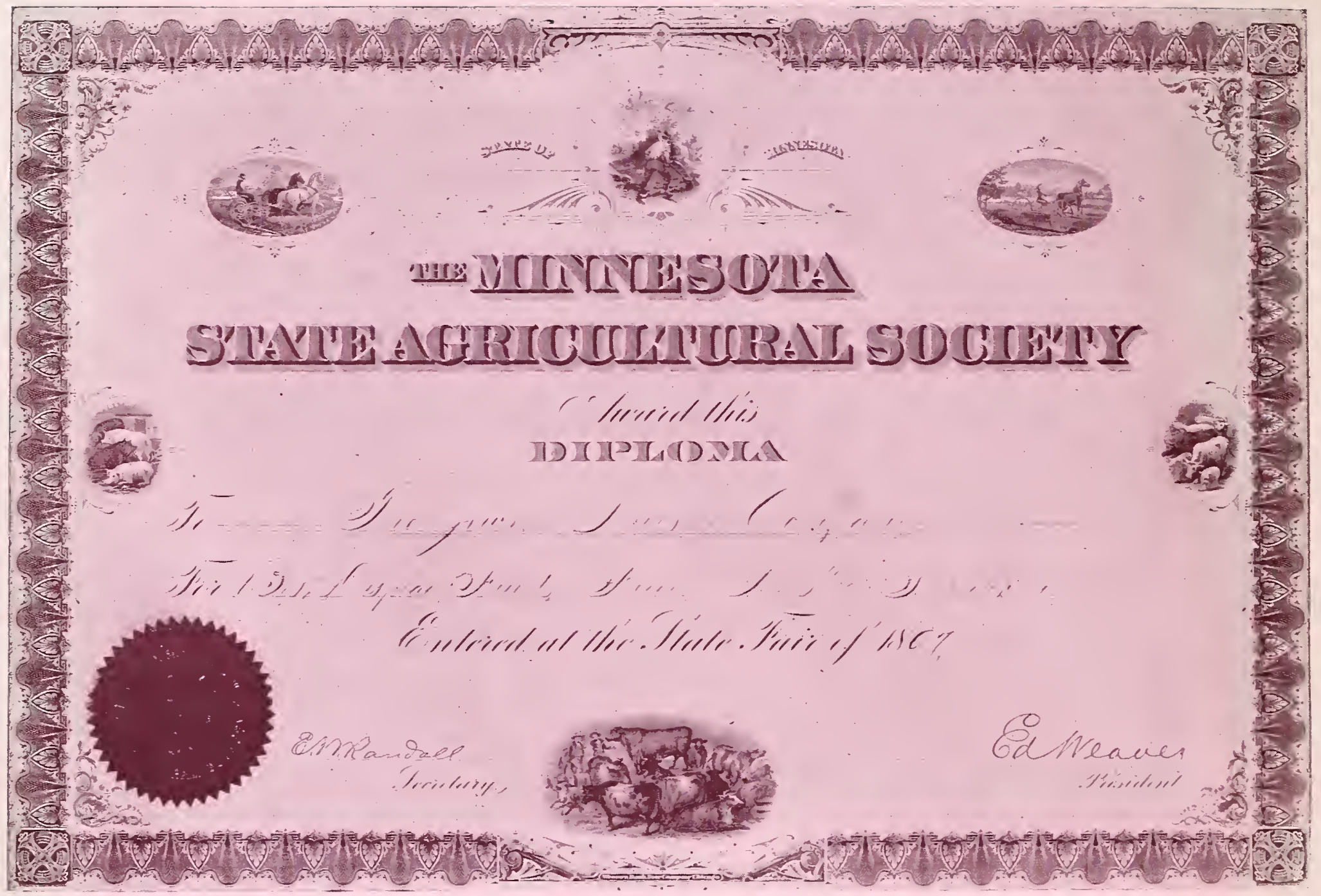

Diploma to "The Jewell Nursery Company for Best Display of Fruits, Fruit Trees and Shrubbery."

The illustration on the front cover, made from a photograph of our exhibit at the Minnesota State Fair, September, 1898 , gives but a limited idea of the extensive display of fruits of various kinds exhibited by us. For this exhibit we received the first premium for the best collection of fruits and an honorary diploma for the best exhibit of fruits and fruit trees, as slown above. There were big apples, crab apples, plums, grapes, currants, gooseherries, raspberries, in fact all the seasonable fruits of Minnesota were represented, and the display, in its dimensions and completeness, was only surpassed by the general exhibit in the Horticultural Hail. It demonstrated that good apples, big red apples, can be grown successfully in Mlinnesota and the Northwest; and the same is true of plums, grapes and small fruits, and there is no good reason why our people should not enjoy all the pleasures of health and comfort that come from a large use of fruits. It is true that fruits can be bought in the markets, but they have not the flavor, the freshness, or the health-giving qualities of fruits grown at home. Our orchards supplied the fruits that gave Minnesota the Wilder medal at the meeting of the American Pomological Society at Philadelphia, Pa., in 1883, and also at the Industrial Cotton Exhibit at New Orleans in 1884, and we received special commendation for fruits supplied the World's Fair Commission in 1892. In addition, we have been successful in securing premiums wherever we have exhibited. We received the first premium and diploma at the Minnesota State Fair, September, 1897, for tlie best display of Iruits, fruit trees and shrubbery-and in 1898, we were awarded a niedal and diploma for the best exhibition of fruits, trees and shrubbery at the Minnesota State Fair. We also secured the first premium and diploma at the South Lakota State Fair, fall of 1897, and at the St. Louis (Minnesota) County Fair, 1897, and at the Stevens County Fair, Minnesota, 1897. We grow this fruit in Minnesota. We have been growing fruits and trees for thirty years in Minnesota. What we can do you can do. We have learned how to grow fruit trees that grow and bear fruit. We have learned that the secret of our success consists in selecting hardy, vigorous trees, that are grown here in the North; trees that are acclimated and have a strong, vigorous constitution to resist the extreme cold and drought. The particulars of this, and much other information acquired in growing trees, etc., we cheerfully offer you free of charge (except a stamp for reply), and we shall be glad to tell you all about “Trees That Grow" and how to make them grow, and also to submit a list of varieties, prices, etc., for your approval. We want your business and we promise you careful attention to your orders, and fair and liberal treatment in every instance. We are the largest growers of nursery stock and farm and field seeds in the entire Northwest. We are responsible (ask anv banker in the state), we live among you, and "we are of your own brethren and kin." You can find us, hence we solicit your business with the firm conviction that we can serve you intelligently and treat you fairly.

If you know what you want, send us your list and let us tell you what we know about it. If you are in doubt and uncertain as to the varieties best adapted to your locality, write us and we will cheerfully assist you, to the best of our ability, to make an intelligent selection that will prove successful. In any event let us hear from you.

There will be no charge, except for our goods, and those we guarantee to be strictly first-class in every respect, and in perfect condition'for planting.

Respectfully yours,

\section{THE JEWELL NURSERY COMPANY,}


MAKE OUT YOUR ORDER ON THIS SHEET AND TEAR OUT.

Parties, in ordering will oblige us in using this sheet, being careful to fill the spaces correctly. Before writing out the order please sec advice on ordering on first page of catalogue. Read carefully, write plainly, and don't forget to enclose draft with your order.

\section{THE JEWELL NURSERY C0., Lake City, Minnesota.}

[Mail, Express or Freight and Route, if any preference.]

Forwarded by

Name

Post Office

County

State

R. R. Station $\}$ and County
If different from post office.

\begin{tabular}{l} 
Date 189- \\
AMOUNT ENCLOSED. \\
\hline P.O.Order, $\$$ \\
Draft, \\
Ex. Order, $\$$ \\
Cash or \\
Stamps, \\
Total, $\$$
\end{tabular}

[Please do not write here.]

Order No.

When Rec'd

Amount Rec'd

Filled

When Shipped

Shipped via.

IOWFR FXPRFSS RATFS Under the new ruling of the leading express companies, advocated and secured by us, LOW $\mathrm{W}$ R RESS RAIES, trees, plants, etc,, packed in closed boxes or baskets, will now be carried at the "Generai Special" rate. This rate means a reduction of 20 per cent from the regular merchandise rates.

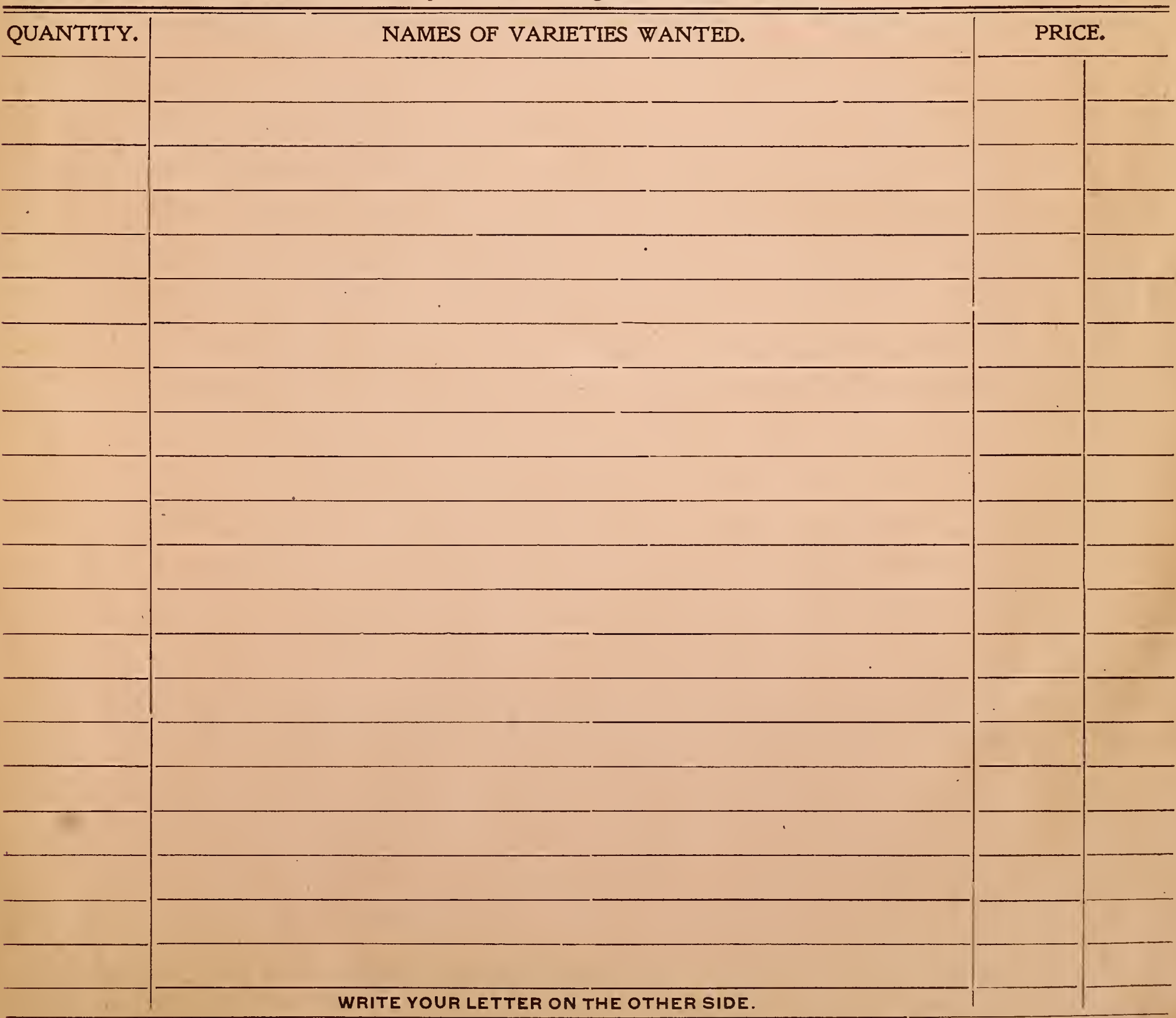




\section{THE JEWELL NURSERY CO.,}

LAKE CITY, MINNESOTA.

Gentlemen: 


\section{THE JEWELL NURSERY COMPANY. Some Information as to Our Facilities.}

$\mathrm{I}^{\mathrm{N}}$

$\mathrm{N}$ presenting our Descriptive Catalogue we are pleased to announce that our stock of trees and plants is of unusually good quality, more extensive than in former years, and the new varieties offer strong inducements to our patrons, to whose orders we will give our best care. We have very commodious and convenient packing houses, grounds and cellars for storing and handling nursery stock. Our facilities in these matters are extensive and complete.

lliustrations. - In order that our customers may become better acquainted with us and our place of business, we have introduced engravings from photographs that faithfully portray some of our surroundings, and show our excellent facilities for doing business. We shall be glad at all times to have our friends visit us, and enjoy the various features of interest of our large 11 ursery.

If you want to get trees and fruits that will grow and bear fruits, buy those grown in the extreme north. One hardy, Minnesota grown fruit tree that is acclimated and adapted to withstand the cold, bleak winters of this country is worth to the planter a half dozen southern-grown trees. Our varieties are all selected with a view to their hardy, vigorous habit and ability to resist cold and drought.

Again, northern-grown trees come into bearing nuch earlier than southern or eastern stock. If you want to be successful with fruit, don't waste your time and money, but buy hardy, northern-grown stock, that is bousid to live and thrive and bear fruit. Send us your orders, and we will send you TREES THAT GROW.

We propose to keep fully up with the times. Our planting this season will amount to over $1,000,000$ trees and plants Some of the principal itenıs are 150,000 Apple, 40,000 Plum, 100,000 Shade, Ornamental and Evergreen trees, 51,300 Grape, 83,000 Currants, 105,000 Raspberries and Blackberries, and 100,000 Ornamental Shrubs, Climbing Vines and Roses.

A pleasant adjunct to our nursery business is our fine herd of Holstein-Friesian cattle. Those interested in stock raising will do well to get our list and prices of this breed of cattle. The Holsteins are large, healthy, vigorous and handsome, and while they stand at the head of all breeds for milk and butter, they take on flesh easily and make excellent beef.

\section{Historical and Descriptive.}

The grounds of the Jewell Nursery Company are located in and adjacent to Lake City, Wabasha county, Minnesota, and from the character of the soil, nursery stock of the finest quality is produced. The fact that we are the most northerly commercial nursery in the United States or Canada, guarantees the hardiness of the stock grown here. The Chicago, Milwaukee \& St. Paul Railway traverses our grounds. The Chicago, Burlington \& Northern Railroad station is distant two miles from our packing houses; these, with the different lines of steamboats plying on the Mississippi river, offer unusual advantages for prompt, speedy and economical delivery of stock.

In the year 1868, Dr. P. A. Jewell established this nųrsery, in the picturesque valley of Lake Pepin. His brother-in-law, J. M. Underwood, who is now president of this company, was then employed as his foreman. They did not seek a location where fruit grew in abundance, and where there were no obstacles to its propagation, but chose to join the advance guard, and, if possible, lead to success in a new country where others had failed, and where it was claimed fruit could not be grown.

The business was started with only ten acres of land, but with a large stock of determination. For ten years the management of Dr. Jewell brought great credit to the nursery, and rapid progress was made in developing those varieties best suited to this cold climate. Upon his death, in 1878, the business passed into the bands of J. M. Underwood, and in 1884 The Jewell Nursery Company was regularly incorporated, under the general laws of tine State of Minnesota, to transact the business of growing and selling nursery stock and pure bred Holstein-Friesian cattle, etc.

We have grown from the start, and although we have passed throilgh severe experiences, we are now strong and vigorous, like the stock we supply. Over 1,200 acres are devoted to the nursery, the Holsteins and farming. Our packing houses, greenhouses, cellars and offices are commodious, covering an area of 30,000 square feet, and are models of comfort and convenience.

The first year only one horse was required to do the work; now 30 are kept busy. A large number of men are employed, and we annually pay out for labor in the nursery more than $\$ 25,000$. It takes over 200,000 feet of lumber annually to box the stock we sell, amounting to over 150 carloads. We have spent more money in experimenting and developing those varieties of fruits and flowers best adapted to this climate, than all other experimenters combined. We mention these facts to show that we have been successfully working for the best interests of Minnesota and the whole Northwest.

\section{BUSINESS DETAILS.}

Remittance for amount must in all cases accompany the order.

How to send money. Money can be sent safely either by Express or Postoffice Order, Bank Draft or Registered Letter. Always send one of the above at our risk.

When you order, do not forget to sign your name. Write it plainly, and give your full address, including town, county and state.

Postpaid by mail means that is all it will cost you. Each package will be done up securely, plainly directed, and the full postage paid on it by us, and safe arrival guaranteed; and we will refill any order that is lost on the way, or has any of its contents injured, free of charge.

By express or freight means that we will deliver the stock to express or railroad here, and the purchaser pays all the transportation charges on receipt of the goods.

We do not send C. O. D., unless 25 per cent of the money is sent with the order. Everything is plainly priced, and return charges on money are an unnecessary expense.

In corresponding, always sign your $n$ ame alike each time.

Regularly authorized agents carry our printed certificates of agency, bearing tlie inprint of our corporate seal.

Terms, cash, unless by special agreement. Packing done in a most careful manner.

Packages will be delivered at the railroad station, after which they are at the risk and expense of purchaser, and in .case of loss or delay the purchaser must look to the forwarding companies alone.

No claims will be allowed unless made within ten days after receipt of goods.

We exercise care that all our stock shall be genuine, unmixed, true to name and quality as represented, and accept your orders with the understanding and agreement that should any prove untrue to name, we will replace them with the genuine, but are not liable for damages other than the amount received for said stock that proves untrue.

Correspondence solicited. Live agents desired. Respectfully, 


\section{Suggestions as to Location. Planting and Care of Hardy Fruit Trees.}

LOCATION. The best is a high northern exposure. If you do not have such a location, select the varieties best adapted to the one you have. Some of the best orchards in the state are on a southern exposure, but the soil is good and their care the best. High ground is very desirable.

SOIL. A clay subsoil is best. It prevents drying out. If not a clay soil, mulch heavily to keep the ground cool and moist.

LAYING OUT GROUNDS. To lay out grounds properly for an orchard, set stakes fiye feet long around the outside, the proper distance apart, then set a row each way through the middle and in line with outside stakes Then dig the holes and set the trees by sighting through to the stakes. In this way the trees will be in perfect row in all directions.

Where a straight row in the garden is required, use a long, one-half inch rope, tie each end to a short handled dibber and thrust them into the ground, stretching the rope very tight, walk along on the rope, and it will leave a satisfactory mark to set by.

DIBBER. A very useful implement is the dibber, which is made in the following manner: The blade should be made from $1 / 4$ inch iron, $81 / 2$ inches long, $21 / 2$ inches wide when finished; draw it out on both sides to an edge and to a point, and with a stout shank 6 inches long. The handle should be $4 \frac{1}{2}$ feet long, 2 inches in diameter, and a ferrule on one end. Insert the shank of the blade in the handle. With this a man can make the holes easily at one motion. A boy puts the plant in and with another thrust of the dibber the hole is tightly closed. For setting large plants a spade can be used instead of a dibber.

PLANTING. Before planting, cut trees and shrubs back vigorously and trim off injured roots. MIud the roots well in thick mud, and plant before it has time to dry. Never expose roots or tops to sun or wind before planting. Holes for trees should be large and deep, unless the soil is wet and heavy, when they should be set the usual depth.

How to set a tree or shrub. Mind this rule, and you will succeed. Sift some fine, rich dirt among the roots, just enough to cover so the boot will not injure them, then with the heel and all the strength and weight you can command, stam $\mathbf{p}$ the earth down until it is solid, then fill in a little more dirt and repeat the stamping until the hole is nearly full; then fill the rest of the hole with loose dirt and leave it with the soil pitching toward the tree from all directions. If it is properly set you cannot pull it up. The same general rule applies to setting everything, from a strawberry plent to a shade tree.

FIRST, do not expose them. SECOND, mud the roots; it is better than pouring on water. THIRD, set firmly, so that you cannot pull up the tree or plant without spoiling it. FOURTH, Ieave ground loose on top and slanting toward the tree or plant.

CULTIVATION. It is always best to cultivate. Keep the ground loose on top and clean; do not cultivate deep. Cease cultivating trees in July, and allow them to ripen. If the ground is dry (in October) after the growth has ceased, cultivate lightly and make a dust blanket to prevent the evaporation of moisture and to appropriate any moisture that falls.

MULCHING. Where you cannot cultivate, mulch thoroughly; put it on thick for three feet around the tree, so as to keep the ground moist and cool, but do not let it touch the tree, as it is liable to heat and burn the bark. It has been found an excellent thing to mulch Raspberries and Blackberries with green clover; cut it when in full bloom and spread it on 2 to 4 inches thick and 12 to 18 inches on each side of the row. This serves to keep the ground cool and is the cheapest fertilizer known.

PRUNING is best done in June. Prune tops and branches severely, and roots moderately, when planting, but afterward only prune sufficient to obtain or preserve the desired form. A low spreading top is preferable.

SUN-SCALD. We give the methods most in favor to prevent sun-scald. First, lean the tree toward the south, so that the rays of the sun at midday will not focus on the body of the tree. Secondly, wrap the body with burlap or rye straw; a string at top and bottom will hold it securely. The burlap prevents injury by rabbits. For mice, clean away all straw or dry grass and weeds and put a little fresh earth around the base of the trees. Poison rabbits with arsenic in sweet apples, and for mice use poisoned corn.

KEEPING. Fruit will keep best in a cool, dry room. Apples should be barreled up tight.

\section{SPRAYING.}

Spray, and get Perfect Fruit. Beyond a doubt, the codlin moth, canker worm, apple and plum curculio, pear and quince leaf blight, grape rot and mildew, currant worm, potato blight or rot, etc., can be prevented or destroyed by spraying with the proper mixtures at the proper times, with the right kind of a pump. The mixtures are inexpensive and easily prepared. The ingredients can be got in any town, and any farmer or fruit grower can combine them. They cost little. The pumps are not nearly so high-priced as many suppose, and with ordinary care a pump will last for years. The operation of spraying is simple, inexpensive, and so effective that it cannot be too strongly urged. It is safe to say that it will double an income from an orchard.

What to use. The following will be found reliable formulæ for preventing leaf blight and destructive insects which infest fruit trees, etc.

APPLES. To destroy the codlin moth, canker worm and apple curculio, use one pound of London Purple to 160 gallons of water. Spray the trees soon after the blossoms fall, when the apples are the size of a pea. The second application should be made a week or ten days after the time of the first, and the third application should be made in a week or ten days from the time of the second spraying. The third application is made necessary when the first is followed by a heavy rain. In preparing the London Purple for use, mix thoroughly with sufficient water, to a paste-like consistency ; then stir into a pail of water and allow to stand over night. Strain this through a fine sieve or a coarse cloth into the distributing barrel or tank. A kerosene barrel is a convenient vessel for this purpose

PLUMS AND CHERRIES. Plum Curculio.-Use one-fourth pound of London Purple to 50 gallons of water; spray soon after the petals have fallen and again ten days later. Three-fourths of the cherries liable to injury by plum curculio can be saved by spraying as above, and enough of the plum crop can be saved by the same treatment to insure a good yield. There is no danger to health from its use. Spraying is the cheapest and most practical method of preventing injuries by these insects.

CURRANTS, RASPBERRIES, STRAWBERRIES and GOOSEBERRIES. Currant worms, and the slugs and insects which infest raspberry and gooseberry bushes and strawberry vines, may be destroyed by one. ounce of powdered white hellebore mixed with two gallons of water.

GRAPE VINES. It has been demonstrated that downy mildew, powdery mildew, black rot, and anthracnose can be controlled by intelligent spraying with Bordeaux Mixture.

Bordeaux Mixture (A). Dissolve 16 pounds of sulphate of copper in 22 gallons of water; in another vessel slake 30 pounds of lime in six gallons of water. When the last mixture has cooled, pour it slowly into the copper solution, taking care to mix the fluids thoroughly by constant stirring. It is well to have this compound prepared some days before it is required for use. It should be well stirred before applying. Another satisfactory formula is given as

Bordeaux Mixture (B). Dissolve six pounds of sulphate of copper in 16 gallons of water, and slake four pounds of fresh lime in six gallons of water. When cool mix the solution as described above.

Treatment. As a first step, every precaution should be taken to remove as much of the infectious material as possible. With this object in view, the old leaves and rotten berries should be carefully collected in the fall or winter and burned or buried. 


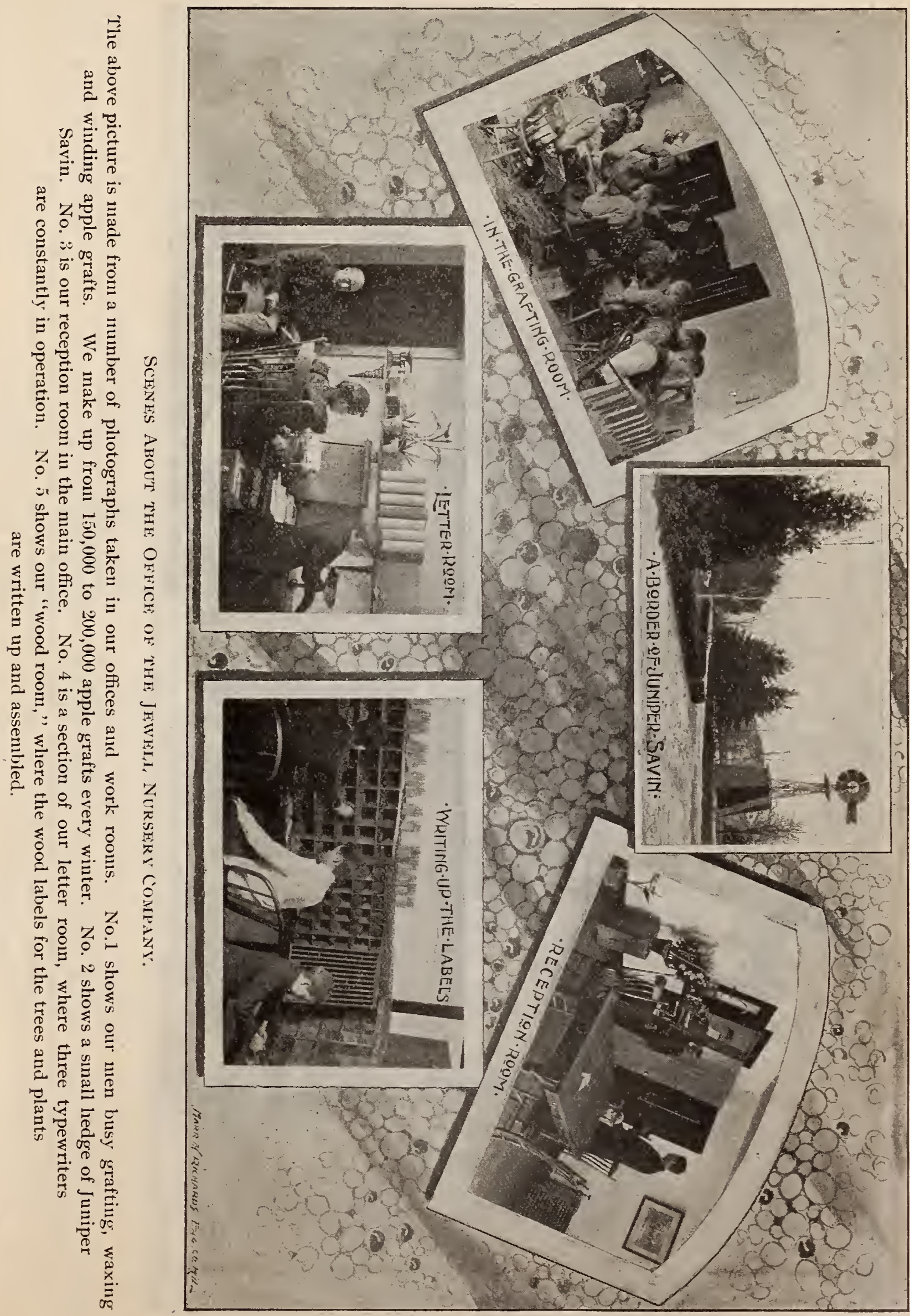




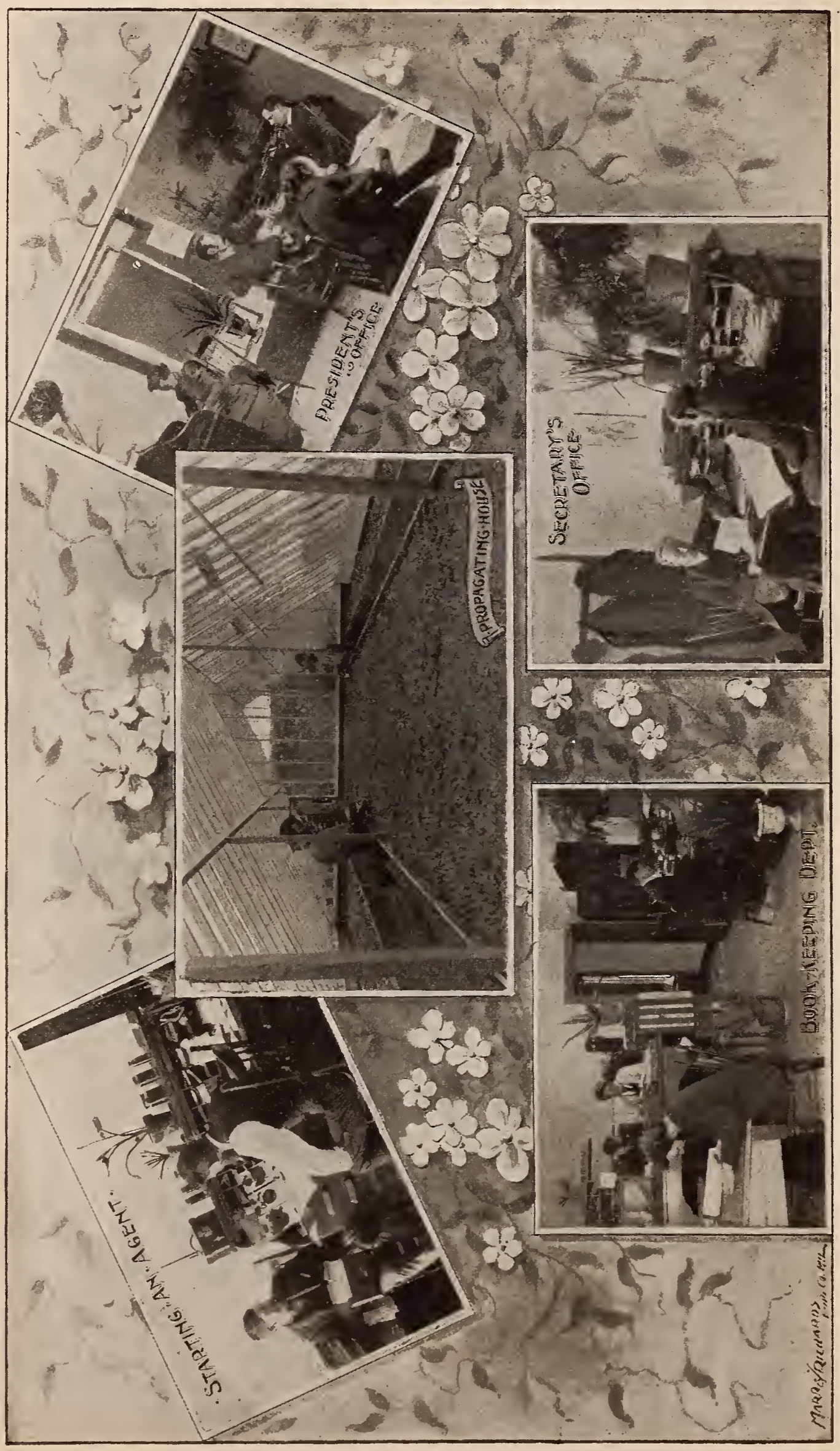

$\frac{8}{8}$

$\div$

¿

$\because$

ह

施

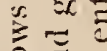

氞

$\because \overline{\mathrm{s}}$

$\therefore \quad \dot{\circ}$

学

产

运总导

可它

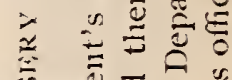

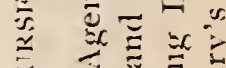

7 范

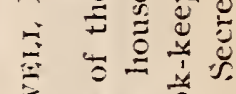

空我气 气

言 $\Xi \Xi$

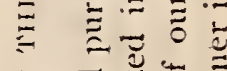

う 苛

\% y क ए

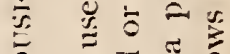

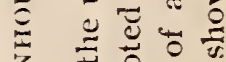

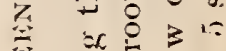

吾

$\approx \approx$

至

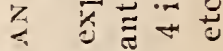

\&

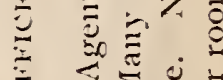

¿

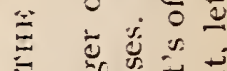

Z

× $\frac{\pi}{\bar{z}}$

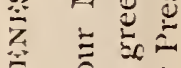

范,

$\therefore$ 我

至

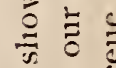

+4 它

苟

$\therefore$ 的

江

$=$

$\% \stackrel{\Xi}{\Xi}$

苞 
Trimmings should also be burned, as they often harbor thousands of minute spores or reproductive bodies of the fungus. In all cases it must be remembered that these treatments are preventatives, and being such it is sheer folly to wait till the enemy appears before beginning the fight.

In the spring after the vineyard has been pruned and put in order by the plow, but before regetation starts, spray the vines thoroughly with the Bordeaux Iixture, formula (A). The object of this spraying is to destroy any spores of the fungus that may be hidden away in the crevices of the bark. About ten days before the flowers open, spray all the green parts of the vines with Bordeaux Mixture, formula (B), taking care to wet the foliage thoroughly. Spray again with the same preparation when the flowers are opening, repeating the operation every three weeks until the fruit begins to color. The necessity of beginning the treatment early cannot be too strongly urged.

To destroy wooll $\mathrm{r}^{\prime}$ and apple aphis and bark lice, suctorial, or sap sucking species of insects, including chinch bugs, squash bugs, plant lice, leaf hoppers, aphis and bark lice, use the Kerosene Emulsion.

Kerosene Emulsion is one of the most useful of the insecticides, and may be easily prepared as follows: Dissolve onehalf pound of best whale-oil soap in four pints of water by boiling. When the soap is all dissolved, remove from the fire and add eight pints of kerosene, and agitate the whole briskly until a permanent mixture is obtained. This is best done by using a force pump and pumping the mixture with force back into the vessel that contains it. The Emulsion may be diiuted to the desired strength and used at once, or it may be allowed to stand and be used when needed. The strength ordinarily used is prepared by diluting one part of the Emulsion in 10 or 12 parts of water, which makes the kerosene about one-twentietli part of the whole.

\section{CHOICE APPLES.}

\section{PRICES OF APPLE TREES:}

Varieties priced at $40 \mathrm{c}$ each are $\$ 4.00$ per doz. and $\$ 25.00$ per 100 . Varieties priced at $50 \mathrm{c}$ each are $\$ 5.00$ per doz. and $\$ 35.00$ per 100.

Varieties priced at $75 \mathrm{c}$ each are $\$ 6.00$ per doz. and $\$ 50.00$ per 100 .

Our principal stock of Apple trees consists of the following varieties, which have been well proved, and can be recommended as the best now in cultivation.

\section{SUMMER APPLES.}

Duchess of Oldenburg. (Russiant.) Tree a moderate grower, upright in habit; bark dark in color, and very smootlı; fruit extra size, pale green, shading to white, beautifully striped pink; tender, juicy, tart, highly esteemed for market or domestic is ; an immense bearer. This is the standard Apple for hardiness, and is doing well more universally throughout the Northwest than any of the old varieties. August and Septenber. Price 40 c each.

Tetofski, Haas, Fameuse. Price $40 \mathrm{c}$ each. All good summer Apples.

Charlamoff. Price 50c each.

\section{WINTER APPLES.}

Wealthy. A seedling originated by Peter M. Gideon, at Lake Minnetonka, Minn. A fine nursery tree; very hardy : an early and abundant bearer ; fruit large, dark crintson in color; flesh crisp, subacid, white tinged with red; quaiity second to none. This tree is deservedly making a first-class record wherever planted. Norember to February. Price, 40 c each.

Wolf River. A 11ew and beautiful fruit of the very largest size. Originated near Wolf River, Wis., and may well be classerl among the ironclads. Skin a greenish yellow, shaded with crimson; flesh white, juicy, tender, with a peculiarly pleasant, nilil, sub-acid flavor; tree a strong grower and great bearer. January and February. Price, $40 \mathrm{c}$ each.

McMahon's White. Originated in Richland Co., Wis. Fruit very large, nearly white; a good culinary and desert tpple. Has proved nearly as hardy and productive as the Dutchess. December. Price, $40 \mathrm{c}$ each.

Northwestern Greening. Originated in the town of Iola, Waupaca Co., Wis. Fruit pale green, sometimes tinter with a little red; sub-acid and of excellent quality. March and April. Price, $40 \mathrm{c}$ each.

Scott's Winter. A Vermont Seedling. Profuse bearer; fruit medium size, thickly striped with bright red; quality inost excellent. Price, 40 c each.

Hibernal. (Russian.) A thrifty grower and a good bearer of large and even-sized, shorry Apples, striped with red, liandsomely colored; sub-acid; good for cooking and eating. December. Price, 75 c each.

Longfield. (Russian.) A free upright grower; an early and abundant bearer; fruit medium to large; yellowish green, with red stripes, a decided blush on the sunny side; rich, sprightly, sub-acid. December to Marcli. Price, 40 c each.

Walbridge, Pewaukee, Talman's Sweet, Utter's Large Red, Golden Russet, Gideon. Price, 40c each. These sorts can be supplied when ordered.

Newell's Winter, Patton's Greening, Avista, Malinda, Peerless. Price, 50c each. New varieties.

\section{HYBRID APPLES.}

These are quite profitable for market, coming into bearing early. Sonne of the varieties are not only good for culinary purposes, but are especially desirable for table use.

There are sereral points to which we wish to call attention, and on which we base our recommendation of these hardy fruits. They can he planted on any kind of soil and in the most exposed situations with perfect safety. They will stand the severity of the changes of the coldest weather. They will come into bearing very early, often in the second year from planting, and bear every year. They are very productive, giving large crops of beautifnl fruit. Some of them are preeminently dessert fruits, being of a superior quality and strikingly handsome. They can be dried, cooked, canted or preserved with the skin on, saving a yreat amount of trouble. The size of the fruit varies from $1 \frac{1}{2}$ to $21 / 2$ inches in diameter, being large enough to quarter and core for drying, etc.

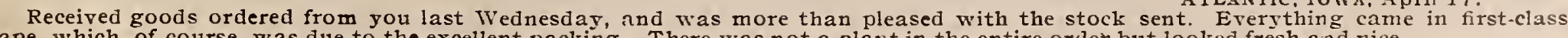
shape, which, of course, was due to the excellent packing. There was not a plant in the entire order but looked fresh and vice. nuluxh, Mixi., May 9, 1896

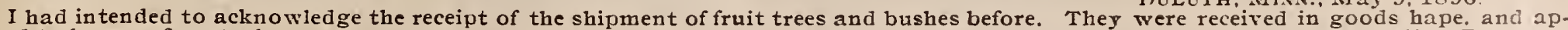
peared to be very fine stock.

E. C. LITTLE.

GRAND MEADOT, MiNN,. June 11,1896.

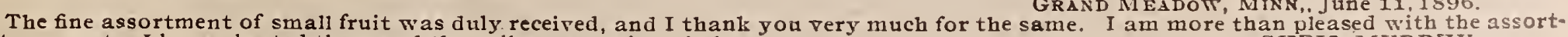
ment you sent. I have planted them and they all are growing nicely. 
Their origin is supposed to have been from seeds of the Siberian Crab fertilized by standard sorts. They possess the merits of extrene hardiness, superior quality of fruit, and of fair size. The following are the most valuable varieties:

Early Strawberry. Tree a good grower, symetrical, hardy ; fruit size of Transcendant; red-striped; crisp, juicy, excellent for eating. Season, August. Price, 40 c each.

Whitney. One of the best growers, straight, symetrical, abundantly supplied with fibrous roots. Fair specimens of the fruit measured $73 / 4$ inches; a delicious eating apple; color bright carmine, very showy; flesh firm, juicy and rich. Said to be of superior value for drying and canning; probably the best of the Hybrids. September. Price, $40 \mathrm{ceach}$.

Orange. Crisp, juicy and pleasant; a deep orange in color a slow grower as a nursery tree; quality excellent. October. Price, $40 \mathrm{c}$ each.

Minnesota. Hardy ; medium grower; fruit larger than Golden Russet ; light color, with blush on sunny side ; quality excellent. In size, beauty and keeping qualities the best of the winter varieties. January and February. Price, 40 c each.

Martha. Immensely vigorous, hardy, annual bearer; quality fine, flavor good ; delicate, creant-tinted ground, two-thirds or more a bright red. Far superior to Transcendent or Hyslop for jelly or canning purposes. Price, 40 c each.

Dartt, Transcendent, Beach's Sweet, Hyslop, Virginia. Price, 40c each. These standard sorts of Crab Apples are supplied when ordered.

\section{SPECIAL APPLES.}

Appreciating the fact that we must depend on our native resources for the best flavored, the hardiest and most desirable fruit, it has been our constant ain to investigate and procure promising varieties; and having tested, to our entire satisfaction, the following Apples, we procured, propagated, and now offer trees of the Okabena and Thompson's Seedlings, under the following guarantee :

That each tree sent out will bear as an evidence of its genuineness a metal tag on which will be indelibly stamped the name of the tree and our registered trade-mark. This tag will be so affixed that it will remain until the tree is in fruiting.

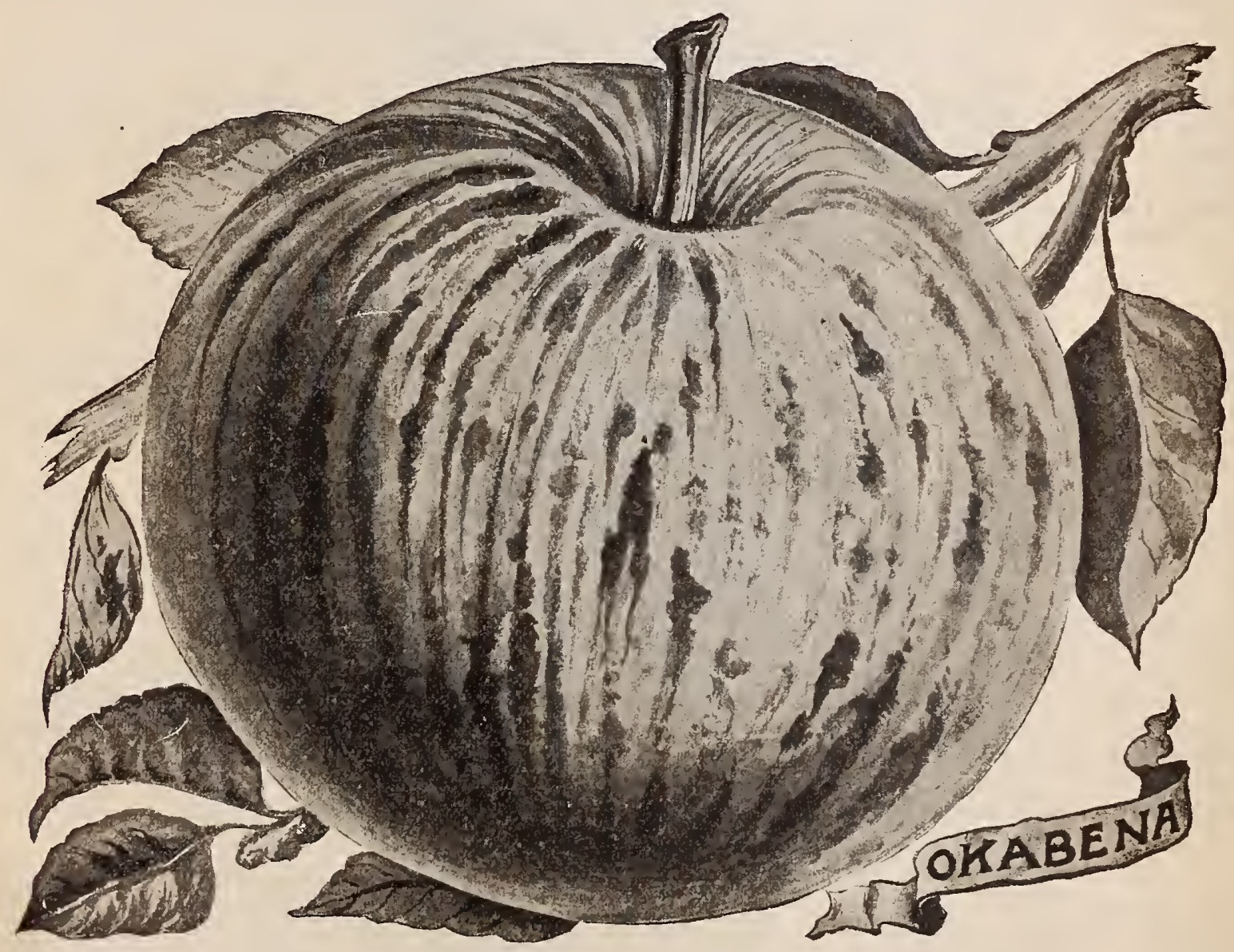

THE OKABENA.

\section{Price, 75 c each; $\$ 7.50$ per doz.; $\$ 60.00$ for 100 .}

THE OKABENA originated on the banks of Lake Okabena, near Worthington, Nobles county, Minnesota. A seedling of the Duchess fertilized by the Wealthy, from seed furnished by Peter M. Gideon, in 1871. The parent tree is perfectly sound and thrifty, and is an annual and enormous bearer. The tree is the finest grower in the nursery we have ever seen; straight, symmetrical and finely rooted. The bark is a deep, rich wine color, not subject to sun-scald or blight! Grows equally well from grafts or burls, and is an ironclad in the fullest sense of the term. The fruit is medium size, slightly flat, liighly colored where exposed to the sun, when it invariably has a solid band of crimson extending fron stem to blossom end; this varies in width from a sixteenth to a quarter of an inch, and is as infallible a mark of the Okabena as the liair line is of the Tallman Sweet. The fruit combines the good qualities of both the Duchess and Wealthy; fine grained, clroice flavored, and a good keeping apple. Season December. For full account of Seedling Commission, see reports of Minnesota State Horticultural Society, year of 1887 , page 136. 


\section{THOMPSON'S SEEDLING APPLES.}

\section{Price 50c each; $\$ 5.00$ per doz.; $\$ 40.00$ per.100.}

Our attention was called to a remarkable orchard, located in Grundy county, Iowa, in 1884, and in 1885 ne consummated the purchase, and obtained absolute right to propagate and sell trees from this wonderful orchard. The history is as follows:

J. S. B. Thompson and his wife Phoebe were residents of New York State. They came to the young state of Iowa in 189.5, and located on the farm where this orchard now stands. In 1861, obedient to the call of his country, Mr. Thompson went to the front, remaining there until the close of the war. In the fall of $1861 \mathrm{Mrs}$. Thompson returned to New York to visit tlie old homestead, and while there, with native thrift, endeavored to temporarily supply the lack of fruit in the new Western honle ly drying a supply of apples. Her father owned a famous seedling orchard, and made it a practice daily to cull the chicest specimens for her use, and suggested to his daughter that the seeds be saved and planted in Iowa upon her return. This was done the following spring, and they started fairly well, and from a pint of seeds about four hundred trees grew and remained in the nursery row fighting for life with the weeds, the ravages of the cattle, and the unfavorable conditions of the crowded nursery row. In 1866 about three humdred trees were transplanted to the orchard site, where they now stand, many of thein being now fifteen inches in diameter, their tops twenty to forty feet in height. Fully half of the original planting still stands, in spite of the unfavorable location. The soil is black prairie, sloping to the south and east, and hemmed in to the east, north and west by dense groves of willow and maple, the southern line of the orchard being a quaking bog. In proof of the trying nature of the location and the superior hardiness of the seedlings we will state that nearly every known so-called ironclad Apple and Crab lias been set in the same orchard, and all are dead or living wrecks, while on the contrary many of the seedlings are perfect in wood, bark and growth. There are among them wonderful developments in size, color, quality and season.

Mr. Thompson has exhibited specimens of these new seedling apples at many county fairs, at the state fairs of Iowa and Minnesota, also at the annual state and district horticultural meetings held in Iowa and Minnesota. He has been universally successful in being awarded premiums, and their superior excellence of flavor and superb keeping qualities have attracted general attention.

In 1891 we exhibited them at the meeting of the American Pomological Society, held in Washington, and they were awarded a Wilder bronze medal, a cut of which is given on page 7 .
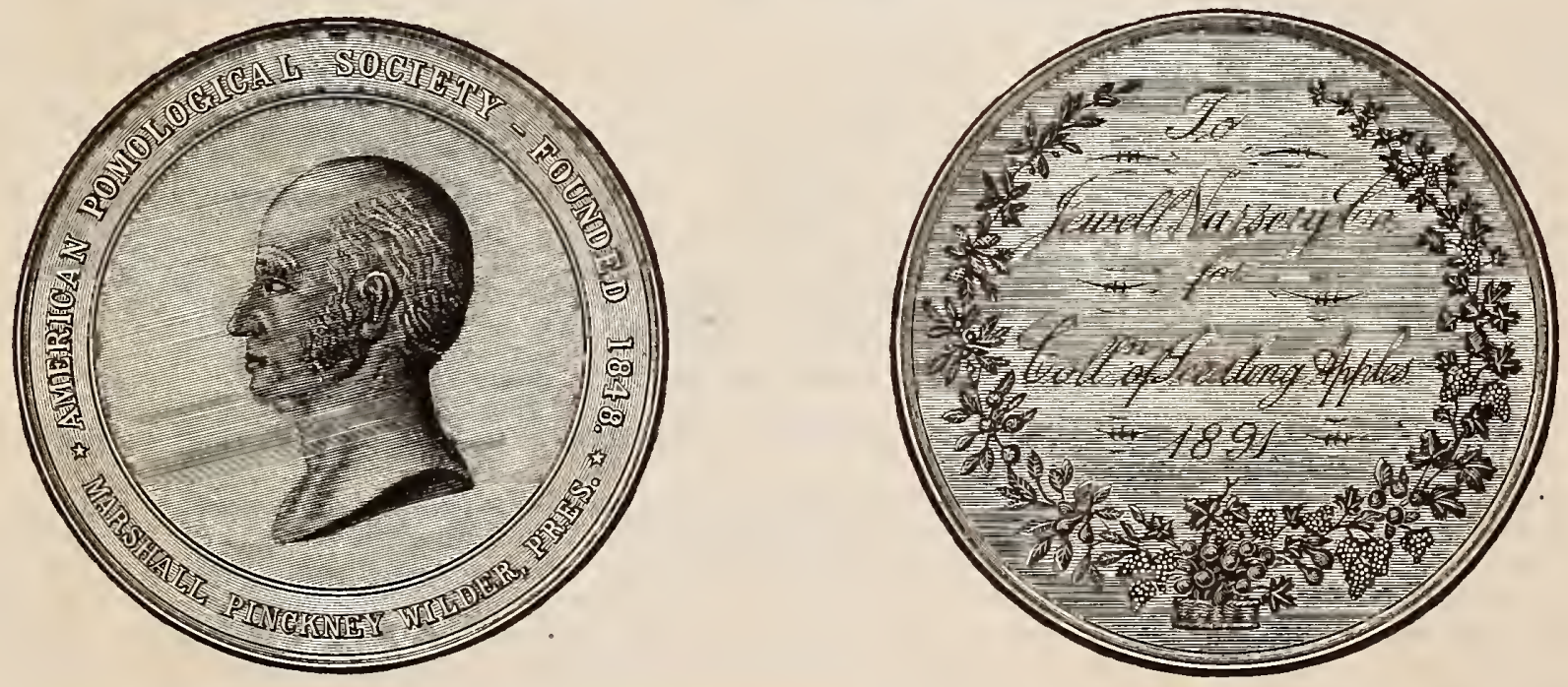

We claim superior merit, from the derivation of the trees; being seedlings from seedlings, and by far the strongest and niost vigorous nursery growers we liave ever propagated.

Interested purchasers are requested to address Hon. J. S. B. Thompson, Grundy Center, Iowa, for niore complete infor111ation.

We believe firmly that these Apples offer the solution to the question, "What shall we set in orchards in the northern fruit belt?" We have placed then on trial in various experimental stations and have tested thenl under most trying circumstances, and now offer the following varieties, which are satisfactory, and embrace a fine collection of early and late, sweet and sour.

Maple. Handsone tree, healthy, and a good bearer. Fruit medium and rather flat; deliciously sweet; color yellow. August. Price, 50c each.

Phoebe. An open and spreading grower; fruit large, green streaked with red, flesh crisp and juicy; tart. Good keeper. Price, 50c each.

Thompson. An upright grower; fruit medium to large; green ground and with red splash; mild subacid; flesli crisp and juicy. Last of March. Price, 50c each.

Grundy. Tree large and spreading. An abundant and annual bearer; fruit large and oblong; flesh tender and juicy, subacid. An excellent dessert Apple. September and October. Price, 50c each.

Judson. A fine open and vigorous grower. Fruit large, oblong; green ground, with a heavy red splash; flesh firm, subacid; an annual and prolific bearer. March. Price, 50c each.

Humboldt, Hardin, Bremer, Soo, Tama. Good varieties, supplied when wanted. Price, 50c each.

PEERLESS. - Originated in Rice county, Minnesota, by Mr. J. G. Miller, who planted seeds of the Ducliess and IIealthy. From these he raised about 200 trees, only fifteen of which survived the severe winter of 1873 . Fron1 these fifteen survivors the hardiest and most thrifty tree was selected, and named the Peerless. In 1885 the tree bore nine baskets of Apples. Specimens were shown at the Minnesota State Fair, and were awarded the first premium over many competitors. The Peerless was also exhibited in the Minnesota collection at the World's Fair, and received a very complimentary notice.

The fruit is large, round, well colored, and is first-class for cooking or eating. The tree is a good grower, with a very heavy dark green foliage, and comes into bearing early. This variety has been sold for a long time at extortionate prices, but it is 110 longer a monopoly. The scions from which our stock is grown are true descendants of the original Peerless Apple tree, and we will warrant every tree sold under the name "Peerless" to be true to name, or we will refund the money paid for it. Don't pay anybody but 50c. each.; $\$ 5.00$ per doz. 


\section{PLUMS.}

Price, 60c each; $\$ 6.00$ per dozen; $\$ 45.00$ per 100 .

In the wild state Plums that produce fine fruit abundantly are found in groups or clumps. Single trees removed fron such groups have been found to be unfruitful, until fertilized by neighboring trees. For this reason we advise to plant in groups or clusters. To form a gromp of trees, mark out a plat of ground 40 feet square, according to the diagram here given, and set a tree at each number, thus bringing the trees in close proximity to eacli other. The pollen will be conveyed from tree to tree, and fertilization ensue.

Another important item is to set different varieties near each other, so that those kinds that have imperfect blossoms may become fertilized by the pollen from trees with perfect blossoms.

Forest Garden. Hardy, bears profusely; one of the earliest Plums; large, being 1 to $1 \frac{1}{2}$ inches in dianeter, oblong; color mottled red and yellow; skin thin; juicy, sweet and rich. Ripens fronl Aug. 1st to 25th. Price, 60 c each.

De Soto. Perfectly hardy; a splendid bearer; fruit very large, 1 1/2 to $13 / 4$ inches in diameter; meat sweet, firm and juicy; dappled red and yellow. Ripens about September 1st. Price, 60c each.

Weaver. The tree is very hardy under all circumstances, and is wonderfully prolific, and an early bearer; the fruit is large oblong; of a beautiful color and exquisite quality; flesh firm, freestone and a good keeper. As a canning Plum, or to be peeled and eaten with sugar and creani, fully equal to the best peach. Price, 60c each.

Hawkeye. Very hardy and thrifty; a strong grower, unusually heavy foliage, and an annual and abundant bearer; fruit is not troubled with curculio; large; mottled, dark red color; attractive and of superior quality, both for eating out of hand and cooking; for canning is unexcelled. The flesh is very firm, bears shipping well, and will be the standard Plum for marketing and homle use. Price, $60 \mathrm{c}$ each.

Wolf. Nearly as large as Lombard, and a perfect freestone, superior for cooking and for serving with sugar as peaches are used; tree a good grower, very hardy, and is becoming popular wherever known. Ripens in August. Price, 60c each.

Rollingstone. A heary and continuous bearer when the tree attains sonie size and age; fruit round, firm-fleshed, and valuable for desert use. Price, 60 c each.

Cheney. Fruit averages quite large; flesh firm, free from astringency, and valuable for market or desert use. One of the earliest native plums. Price, 60c each.

Shipper's Pride, Winnebago, German Prune, Robinson, Imperial Gage, Lombard, Arctic, Pottawatomie, Miner, Forest Rose, Marianna, Wild Goose. Price, 60 each.

\section{AITKIN PLUM.}

\section{Price, $\$ 1.00$ oach; $\$ 10.00$ per.dozen.}

This Plum originated in Aitkin County, Minnesota, not far from Lake Itasca, in latitude $46 \mathrm{I} / 2$ degrees north, and is of the most northern origin of any seedling Plum ever introduced.

Mr. D. C. Hazelton, while engaged in clearing a piece of land adjoining his fruit farm, discovered a Plum tree bearing fruit of large size and excellent quality. He began propagating for his own use. When he came to market the fruit, he found such a demand for these large, luscious Plums that he wrote us concerning them. We requested samples of the fruit, and when they were received we were convinced that he had found the finest native seedling Plum yet discovered. Our experience with seedlings of different varieties taught us to be conservative and careful, and we had a representative visit MIr. Hazelton. He found the fruit and tree all that was claimed for them, whereupon he secured the exclusire control of the stock of this Plum. We have named it "Aitkin," because of its origin in Aitkin County.

The tree is a rapid, vigorous grower, with dark green and very large foliage and bright, smooth bark. The trees fruit at a very early age, the writer having counted 480 large, well-developed Plums on a small three-year-old tree; he was greatly impressed with the uniform size of the fruit, none of them being sniall.

The fruit ripens early in the season, at least two weeks before the De Soto, and thus escapes the early fall frosts, These Plums have a peculiar seed, the shape being flat, and rery thin, presenting an indentation (in the form of a crescent), that distinguishes it from any other variety. The fruit is described as follows:

A greenish yellow ground, turning to a brilliant red, becoming, when fully ripe, a dark red. Tne fruit is oval, slighatly truncated at both ends, and a little paler on the shade side; cavity small and regular. Flesh rich, yellow, tender, juicy nd sweet. Stone large, but remarkably thin; a freestone, and can be pared and served with cream; etc., readily peels when ripe. A prolific and regular bearer, and for culinary purposes cannot be excelled. The fact that this Plum stands the extreme cold incident to latitude $461 / 2$ degrees north without injury, that it ripens very early, and bears extra large fruit of uniform size and brilliant color, makes it the most desirable of our native Plums, particularly for the extreme north, where only the liardiest and earliest varieties can be successfully grown.

\section{THE AITKIN PLUM.}

We are glad to submit herewith the strongest possible evidence of the truth of our clain that the AITKIN is the largest, handsomest, earliest and best native Plum known. Please read the testimonials from the most prominent horticulturists in the IVest concerning it. They tell the story.

We picked AITKIN Plums, fully ripe, August ?,189\%, three weeks before any other variety was fit for use, proving it to be the very earliest Plun grown. Many of these specimens measured $4 \frac{1}{2}$ to 5 inches in circumference (see Dr. Deninis' letter), and they all average very large, in fact are more uniform in size tlian any other Plum we ever saw. While there were many extra large Plums on our trees, there were no small ones. What we want to impress on you is the fact that the AITKIN Pluni is very large, beautifu1, and of an excellent flavor, and it is the earliest Plun known. These facts are established by the evidence of the best known authorities in the West, men who are posted and whose testimony is recognized as truth by all who know. them.

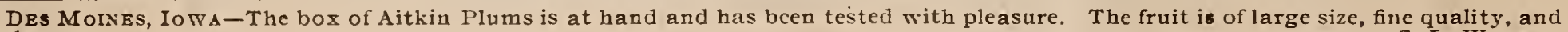
handsome. 
The introduction of the AITKIN makes it possible to successfully grow the Plunin in North Dakota and the far north, where the later ripening varieties are a failure. Its extrene northern origin and the early ripening of its wood make it thorouglily adapted to localities having short summers and cold winters.

Bear in mind, the AITKIN Plum will give you fruit in off years when all others are caught by Jack Frost. Had we had a severe frost any time before August 21st, the AITKIN is the only Pluni we should have had to ripen on our grounds this year. Again, it peels like a tomato, so the skin may be entirely removed with little effort. Four hundred and eighty large Plums, fully 111atured and ripened, have been produced
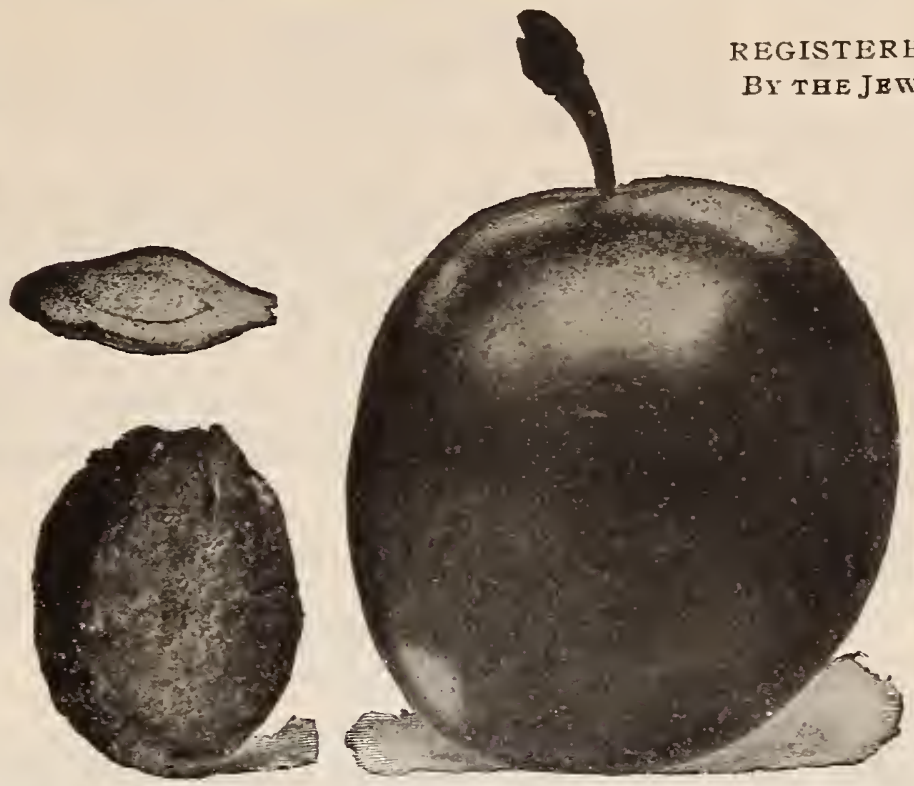
REGISERED TRADE MARK. by a tree three years old. What more known and the trees bear fruit at one and two years from planting,

Read the evidence presented and then plant the AITKIN Plum. You need have no fear. It is the grandest and best Plum grown. No man who fruits it once will be disappointed. Don't be afraid to giye it a trial.

\section{U. S. DEP'T $T_{2} O F$ AGRICLLTURE, Office of County Correspondent,} Minnesota City, Minn., Aug. 17.

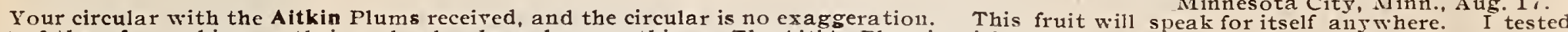

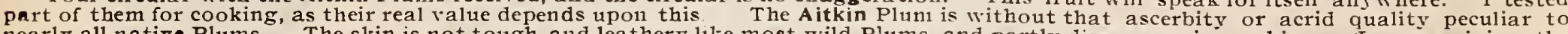

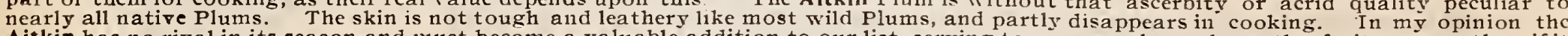

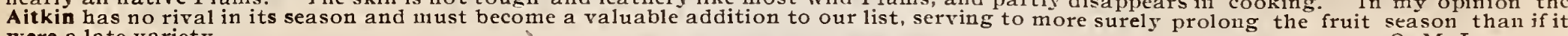
were a late variety.

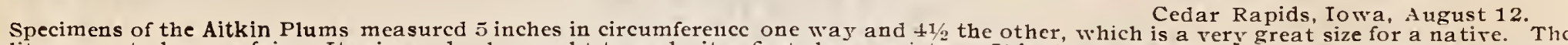

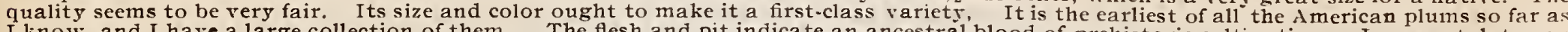

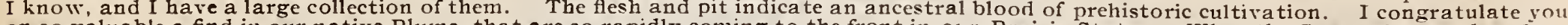

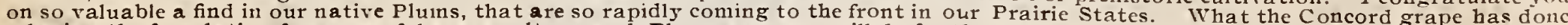
n laying the foundation for successful grape culture, such Plums as yours will do for the Plum culture in the near future.

DR. A. B. DexNis, Horticulturist.

Montreal, Canada. A ugust 14.

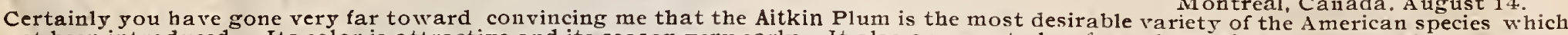

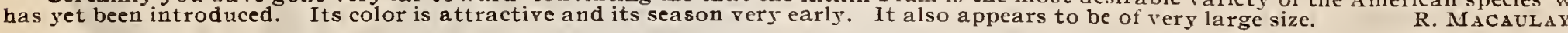

La Crescent, Minn

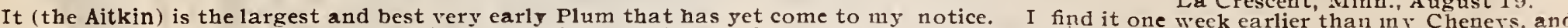

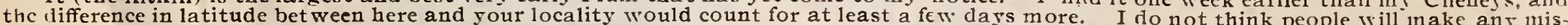
take in planting it freely.

J. S. HARRIS, Horticulturist and Fruit Specialist. State Horticultural Society of IVisconsin. West Salem, Wis., August 16

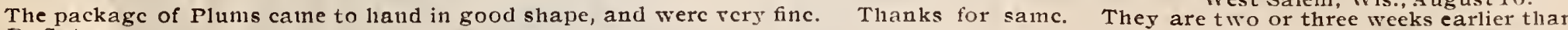
our De Sotos.

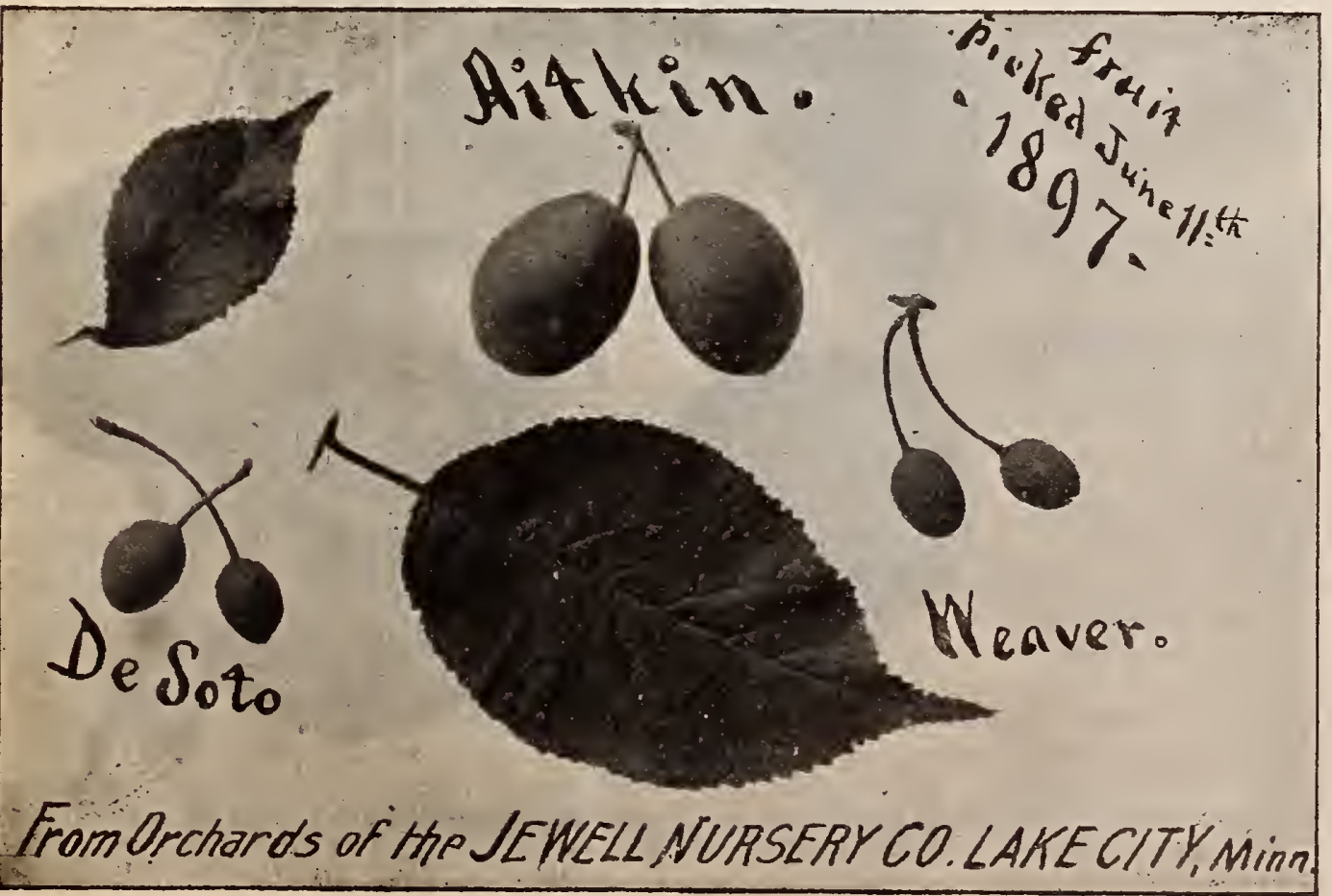

This illustration shows the comparative size of the Veaver, De Soto and Aitkin Plums, June 11, 1897. The wonderful development of the Aitkin stamps it as a very early, rapid growing rarietv, and is also a sure indication of a very large fruit at maturity. The Aitkin ripens so earty that a long season is allowed for the new wood to become liard and firm before winter setsin. This is one of the cliief reasons why this Plum tree is so liardythe wood is ripe and ready to resist the colil winters.

Dr. A. B. Dell11is of Cedar Rapids, Iowa, is probably the best authority on Plunis in the West. He has every variety that he can secure, on trial in his experimental orchard, and he says Cedar Rapids, Iowa, June 12

It is indeed a great surprise to me to sec rour Aitkin Plum of such a wonderful size this early in the season. They are fully four times as large as the Weaver and De Soto. The difference was so great that I mcasured the Aitkin, and it was almost a half an inch in Aitkin, and it was almost a hal an This beats any other native Plum at this sea= This beats any other have plum at this sea growing on $\mathrm{my}$ place. It is not only a rers growing on my place. It is lot only a

early Plum, but also a very large one. 
Cedar Rapids, Iowa, August 18.

I enclose order for 20 trees, two years old, 5 to 6 feet high, of Aitkin plums for my orchard. I should like to plant at least 50 trees, as it is the largest American Plum I know of. When these native Plums come to be better known they will out-sell the half-ripe trash shipped into our large cities from the Pacific coast. You and any others who introduce such Plums as the Aitkin, are doing a great work for horticulture in our prairie regions.

A. B. DenNis, Horticulturist.

The Northwestern Farmer of St. Paul says:

The De Soto has long been the standard by which native plums have been measured, both as to size and quality, hence plums picked on the same date, growing under similar conditions and averaging four times as large as the De Soto naturally inspire one with a desire to know more of the variety.

Well ripened specimens of the new Aitkin Plum submitted August 9 th confirm all the good things that have been said of it. The general appearance is rery attractive, and the quality good. These, added to the fact that the tree is both hardy and prolific, make up the sum of good qualities necessary to recommend it for the family garden or the commercial orchard.

Windom, Minn., June 22.

The sample of Plums you sent me for comparison, on the 19 th inst., was received $O$. K. and carefully noted. The Aitkin was from six to ten times larger than" either the Weaver, Wolf, De Soto or Hawkeye. In comparing the Aitkin with the Cheney and sereral of the Manitoba varieties which are noted for their early devlopment, we found the Aitkin much larger than any of them. From what I know uf it I believe it to be a decided advance over any plum I know of, and the most promising variety known for Northern planters. I will also say that you mayconsider yourselves public benefactors in introducing the Aitkin Plun.

DEWANE COOK.

With all this evidence you can surely afford to try the Aitkin Plum, with a firm conviction that you will have fine fruit and plenty of it. We know the Aitkin Plum is the best native Plum in existence. Please give it a trial and we will back up every claim we have made for it.

\section{APRICOTS.}

Price, $\$ 1.00$ each; $\$ 9.00$ per dozen.

Plant 15 feet apart each way. There is no fruit more delicious and beautiful than the Apricot. The hardiest of all the Apricots, the Russian has stood 30 degrees below zero without injury, while the Moorpark and Breda were frozen to the ground, and it is free from all disease, worms and insects that have been so destructive to trees and fruit of the Peach and Plum. We have seen a great niany of these trees growing in the Mennonite settlements of Nebraska, and have the first tree to see that was not perfectly liealthy, vigorous and symmetrical. Fruit of medium size and of the best quality, and brings the highest price in the market. Its habit of growth is dwarf in nature, and jt is easily protected. The quality of the fruit is so fune that it is well worth the trial and trouble of amateurs to experiment with it.

IMPROVED RUSSIAN VARIETIES.

Alexander, Alexis, J. L. Budd, Catherine, Nicholas, Gibb. Price, \$1.00 each.

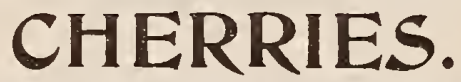

Price $60 \mathrm{c}$ each; $\$ 6.00$ per doz.; $\$ 45.00$ per 100 .

Early Richmond. An early red, acid Cherry, very valuable for cooking early in the season. Ripen through June. Tree a free grower, hardy, nealthy and very productive. One of the best. Price, $60 \mathrm{c}$ each.

English Morello. Large, dark red, nearly black; tender, juicy, acid, rich. Tree dwarf and slender. Makes a fine tree on the Mahaleb. If trained on the north wall it may be in use all the month of August. Taluable. Price, $60 \mathrm{c} \mathrm{each.}$

Olivet. Large; very shining, deep red; tender, rich and vinous, with a very sweet subacidulous flavor; promising. Price, 60c each.

Ostheim, or Russian Cherry. A hardy Cherry, imported from the 11urseries of I)r. Regel, of St. Petersburg, Russia. It has been tested in the severest winters of Ninnesota, and found to be perfectly hardy. Charles Downing thus describes it: "Fruit large, roundish obovate; flesh liver color, tender, juicy, almost sweet, subacid; very good. Season middle of July:" Morello class. Price $60 \mathrm{c}$ each.

Sand Cherry. A fine shrub; extrenely liardy; useful where it is difficult to raise a general varietr of fruit; very prolific; fruit black, jucy and excellent for sauce and pies. Price, 50 c each.

Montmorency, Black Tartarian, Kentish, Luelling. Price, $60 \mathrm{c}$ each.

\section{PEARS.}

Price, \$1.00 each; $\$ 10.00$ per doz.

Kieffer's Hybrid. Raised from seed of the Chinese Sand Pear, accidentally crossed with the Bartlett or some other kind grown near it. Tree has large, lark green, glossy leares, and is of itself very ormamental; it is an early and very prolific bearer. The fruit is of good quality, wonderfully showy for table and niarket. It never rots at the core, and is as liearly blight proof as it is possible for any Pear to be. October and November. Price, $\$ 1.00$ each.

Clapp's Favorite, Flemish Beauty, Bartlett. Price, $\$ 1.00$ each.

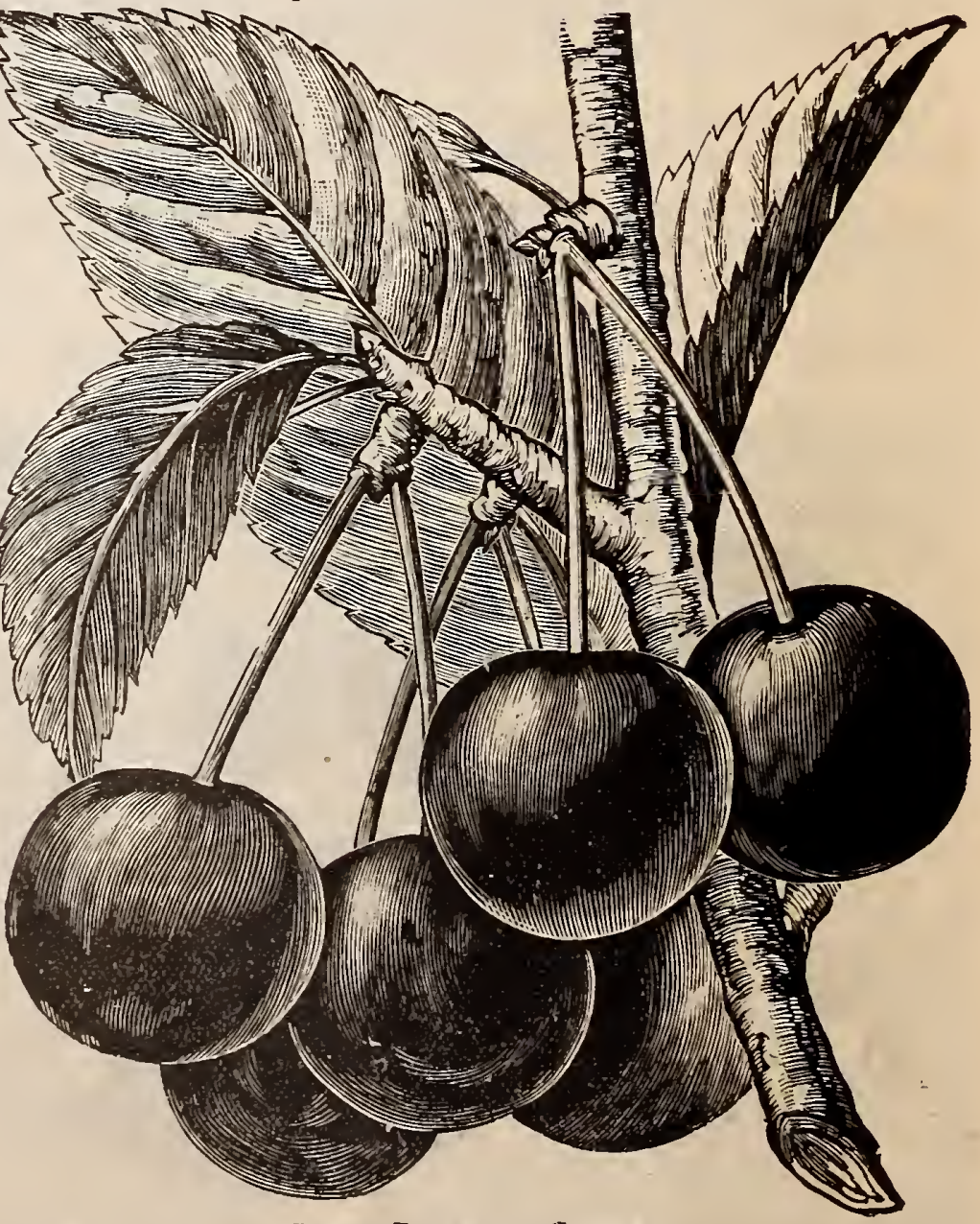

Bessemianka, Idaho. Price, \$1.25 each. Standard sorts. 


\section{PEACHES.}

Price, 75 c each; $\$ 7.50$ per doz.; $\$ 50.00$ per 100 .

It has not been thought possible to grow peaches in Minnesota, but our venerable and progressive friend, Peter M. Gideon, of Excelsior, has demonstrated that it can be done successfully, and now there are a number of planters in the state who are following his example. A good many peaches were raised last year, and some fine specimens were exhibited at the Minnesota State Fair, also at the winter meeting of the Minnesota State Horticultural Society.

Crawford's Late, Crawford's Early, Amsden, Heath Cling, Mountain Rose, Wonderful, Salway. These are the best sorts for general planting. Price, 75c each.

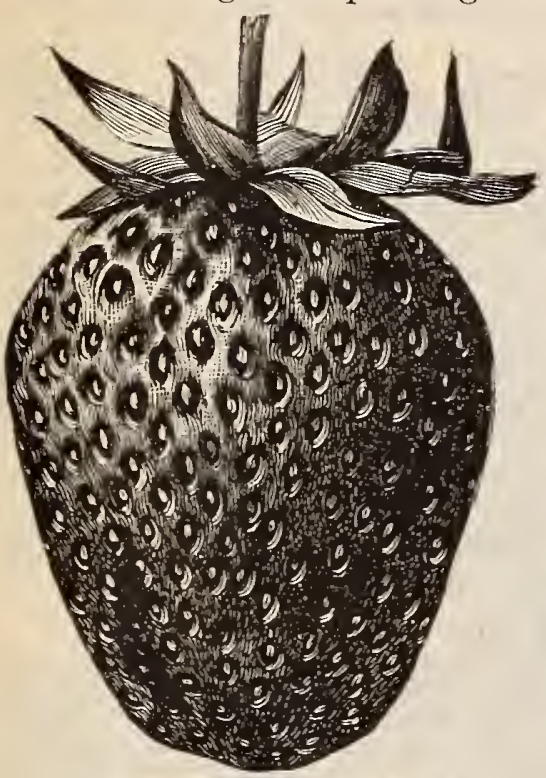

BEDER WOOD STRA IVBERRY.

\section{STRAWBERRIES.}

Price, 75 c for 50; $\$ 1.50$ for 100 .

In setting pistillate varieties, be sure and set staminate varieties near then, either mixing them, or plant three rows of pistillate, then one of staminate. The staminate variety furnishes the pollen which fertilizes its own and the blossoms of the pistillate plant also.

\section{STAMINATE VARIETIES.}

Parker Earle. A splendid new berry, which originated in Texas and was named in l1onor of Mr. Parker Earle; uniformly large, regular, conical, with a short neck; color glossy, scarlet crimson; ripens all over; flesh moderately firm, no hollow core, quality good; flowers perfect, always setting perfect fruit.

Beder Wood. Originated at Moline, Ill. By some considered the rery best early berry. It is immensely productive. The plant is a good, healthy grower, and sends out a large number of runners. Fruit large, conical, bright red, and of excellent quality. An excellent fertilizer for the Warfield.

Wilson's Albany, Van Deman, Captain Jack, Workman, Crawford, Sharpless, Jessie, Gandy, Pearl.

\section{PISTILLATE VARIETIES.}

Warfield. A seedling discovered by B. C. Warfield, of Illinois, in 1883 . It fruited in 1884 , and a bed containing $\bar{j}$ square feet yielded a quart every second day. The blossom is pistillate. Plant a vigorous groxver, with long penetrating roots, to resist drought. It blossoms and ripens with the Crescent, and has tall leaves that protect the blossoms from. spring frosts. Single plants have produced 195 blossoms and berries. It equals the Wilson as a shipper, and is superior to it in every other respect. We consider this as the coming market berry.

Crescent Seedling, Bubach (No. 5 ), Princess.

Haverland. Originated in 1882, by B. H. Harerland, of Hamilton county, Ohio, from seed of the Crescent fertilized by the Sharpless. During the past dry season it made a better growth than any other variety. Not a spot of rust appeared on it: wonderfully productive. The originator says: "It is, perhaps, the most productive of any Strawberry now cultivated. The berries are firn, uniform in shape, very large, and of most excellent flavor and bright red color. It sells niore readily and brings a better price than any other Strawberry. The plants are very large, healthy, vigorous, and ripen their fruit evenly and early, holding on through the season.'

\section{GRAPES. \\ BLACK VARIETIES.}

Varieties priced at $15 \mathrm{c}$ each are $\$ 1.50$ per doz.; $\$ 10.00$ per 100 .

Varieties priced at $25 \mathrm{c}$ each are $\$ 2.50$ per doz.; $\$ 20.00$ per 100 .

Varieties priced at $50 \mathrm{c}$ each are $\$ 5.00$ per doz.; $\$ 30.00$ per 100.

Varieties priced at $\$ 1.00$ each are $\$ 10.00$ per doz.

Campbell's Early. A new grape that pronises to take a front rank among the early black Grapes. Indeed, it is claimed by many of the highest authorities, to be the very best Grape yet produced. This Grape has been submitted to the most severe test, and has as yet, shown no fault, but rather exceeds our expectation. It has a strong, vigorous vine, with a thick, heavy foliage, and perfect self fertilizing blossoms, thus insuring a full crop. The clusters are very large, shouldered, compact, and handsome, but not crowded. The individual berries are very large, sometimes an inch in diameter, nearly round, with a light purple bloom. Skin thin but strong, bears handling and is a good shipper. In flavor a rich, sweet vinous taste, with no acidity from the skin; flesh firm but tender, and but a few small seeds. In season it is very early, coloring somewhat in July and ripening from the middle to the last of August. It is a remarkable keeper, hanging upon the vines sound and perfect for a month to six weeks after ripening. No new Grape introduced in the past 25 years has received a tithe of the praise and commendation that has been bestowed upon the Campbell's Early. Price, 2 year No. 1 plants, \$1.00 each.

Early Ohio. New black. Originated at Euclid, Ohio, by Mr. R. A. Hunt. Bunch large, shouldered, berry medium. The earliest Grape known, ripening fully 10 days earlier than Moore's Early. Unlike most early varieties, the berries never shell, a quality highly appreciated by those who grow grapes for market. Vine a strong grower and very productive, perfectly hardy; having stood uninjured in very severe weather when Concord buds in the same vineyard were ruined. In growth, foliage and gelleral habits the rine resentbles the Concord. Price $\$ 1.00$ each.

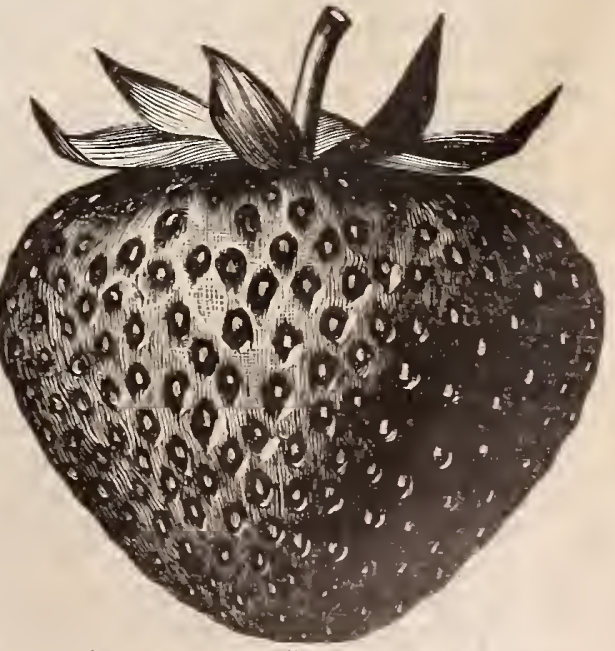

WARFIELD STRA WBERRY. 
Janesville. A very desirable Grape on account of hardiness, quality and early ripening. Color black; bunch solid; very good flavor; when fuliy ripe quite sweet. Ripens from the 15th to the 20 th of August. Price 25 c each.

Moore's Early. Black, with heavy blue bloom; bunch medium size; berry very large; better than Concord in quality, and with n1ore pulp; vine a moderate grower, very healthy and hardy, moderately productive; a valuable market variety on account of its earliness. Ripens some 20 days earlier that the Concord. Exempt from mildew and blight. Price, 50c each.

Wilder. (Rogers' No. 4). Black; bunch and berry large, of excellent quality and a good keeper; vine a moderate grower, hardy and productive, but liable to overbear. Ripens with the Concord. Price, 50c each.

Worden. Black; bunch very large and compact; berry very large; fully as productive, hardy, and as strong a grower as the † Concord; quality much better, and ripens a few days earlier. Will not keep as well, but if handled when first ripe is as good a shipper as the Concord; is steadily increasing in popular favor. Price, 25 c each.

Eaton, $\$ 1.00$ each; Hartford, $25 \mathrm{c}$ each; Champion, $25 \mathrm{c}$ each; Ives, $25 \mathrm{c}$ each; Concord, $15 \mathrm{c}$ each.

\section{RED GRAPES.}

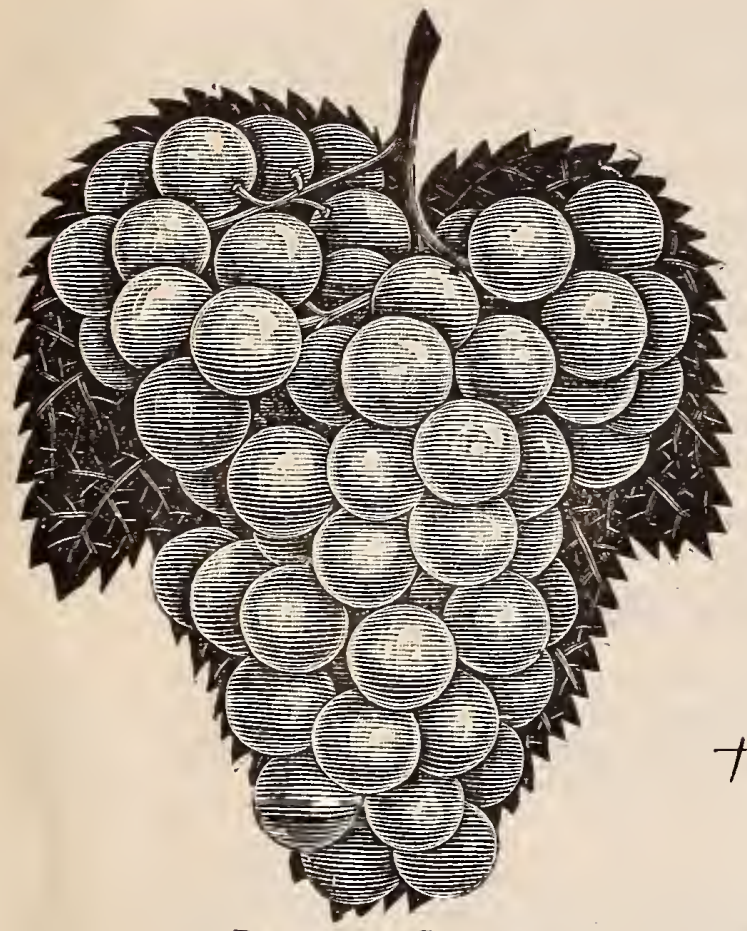

BRIGHTON GRAPE.

T Agawam. (Rogers' No. 15.) Vigorous grower; bunch good size, shouldered rather loose; berries large and round; color darker than Delaware; skin thin, with juicy pulp; very eweet, with rich aromatic flavor. Season 10 days earlier than Concord. Price, 25 c each.

Brighton. Of recent introduction, and truly a superb Grape. In color fbrm of bunch and berry it resembles the Catawba, combining the sprightliness of that variety with the richness and sweetness of the Delaware. Vines vigorous, hardy, productive, and quite free from mildew. Price, 50c each.

- Delaware. Rather slow grower. Bunch medium compact; berries medium, skin thin, dark red color; flesh tender and juicy, exceedingly sweet. Ripens in September, and, as a rule, commands in market from one-third to one-half higher price than the ordinary varieties. Price, 50c each.

Lindley, 25c each; Massasoit, $50 \mathrm{c}$ each; Moyer, $\$ 1.00 \mathrm{each}$.

\section{WHITE GRAPES.}

t Lady. This variety as yet has not developed a weak point. It ripens in advance of the Concord; is hardy, vigorous and productive; has no superior in resisting mildew. In color it is a yellowish green; pulp tender, sweet, rich and spright1y. It is a seedling of the Concord, and is a very good and reliable white Grape for all localities and climates. Price, $\$ 1.00$ each.

Niagara. Probably next to Concord, the most extensively planted Grape in America. Bunches very large, often weighing one pound; berry large; immensely productive, a rank grower; quality when in its best condition excellent; a little earlier than Concord; has a flavor peculiar to itself that is esteemed by many. Price, 50 c each.

Moore's Diamond, $\$ 1.00$ each; Pocklington, 50c each; Empire State, 50c each; Martha, $25 \mathrm{c}$ each; Elvira, 25c each. All the above are well-known varieties.

\section{GOOSEBERRIES.}

Varieties priced at $25 \mathrm{c}$ each are $\$ 2.50$ per doz., $\$ 15.00$ per 100. Varieties priced at 50c each are $\$ 5.00$ per doz., $\$ 30.00$ per 100 . Varieties priced at $75 \mathrm{c}$ each are $\$ 7.50$ per doz.

A deservedly. popular fruit, making, as it does, the richest of canned fruit for winter consumption, and also, as is the case with the improved varieties, being excellent for eating out of hand. Set in rows 6 feet apart, 4 feet apart in row,

Downing. Fruit larger than Houghton, roundish, light green, with distinct veins; skin smooth; flesh rather soft, juicy and very good; vigorous and productive. Price, 25 c each.

Industry. An enormous English sort. Price 50c each.

Pearl. A new variety of great merit; twice as large as the Downing, and fully equal to it in quality. Probably the most productive Gooseberry grown. In quality the very best. Nearly sweet and of excellent flavor. Free from mildew. At the Michigan State Experimental Station, on a 10 point scale, it is noted for productiveliess 10 , and for quality 9 , none surpassing it. Price, $75 \mathrm{c} \mathrm{each.}$

Red Jacket. A new red berry, as large as the largest; smooth, very prolific and hardy; quality and foliage the best. For many years it has been tested by the side of the best American and English sorts, and is free from mildew, either in leaf or fruit. Promises to be the variety we have solong been waiting for; equal to the best English kinds, and capable of producing large crops wherever gooseberriescan be grown. Price, $75 \mathrm{c}$ e a ch.

Transparent. New, very hardy; bushes of strong, vigorous growth, maturing and fruiting early; bears abundantly; berries almost as large as Downing; pale greenish. Price, 25 c each.

Triumph. An American seedling of the English type; large, hardy and an immense bearer; very promising. Price, $75 \mathrm{c}$ each.

Houghton's Seedling, American. Price, $25 \mathrm{c}$ each.

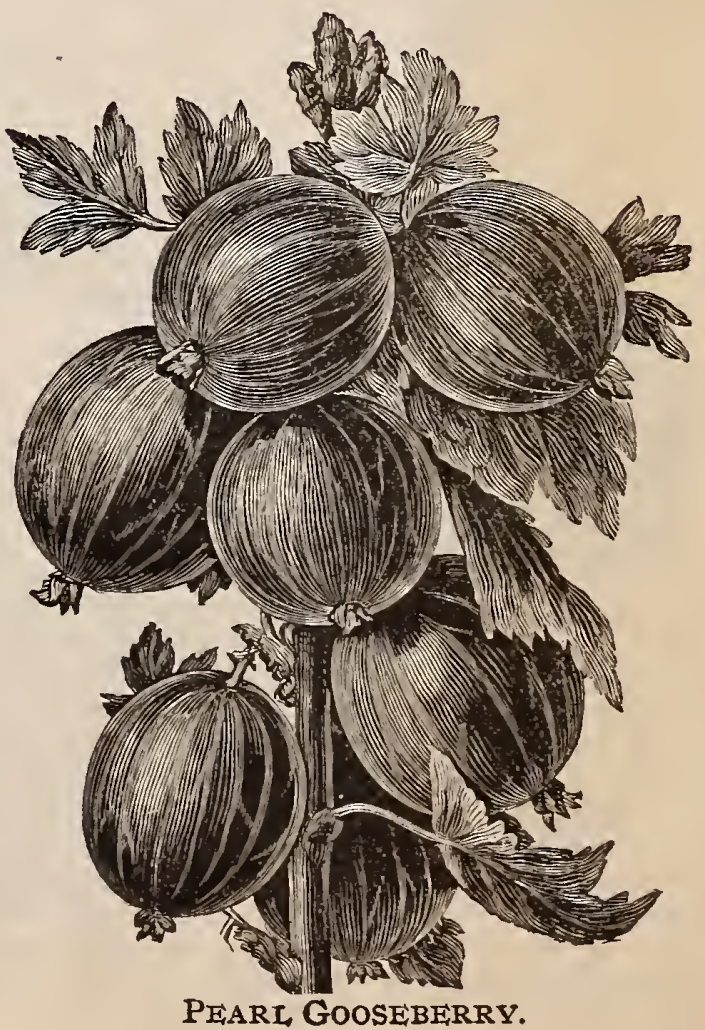

PEARL GOOSEBERRY. 


\title{
CURRANTS.
}

\author{
Varieties priced at $25 \mathrm{c}$ each are $\$ 2.00$ per doz. and $\$ 12.50$ per 100 . \\ Varieties priced at $30 \mathrm{c}$ each are $\$ 3.00$ per doz. and $\$ 15.00$ per 100 .
}

North Star. The points of excellence are its hardiness, vigorous growth of wood, early fruiting and great productiveness. The average growth for 1889 (an extremely dry season), on light, gravelly soil was from 30 to 36 inches. The fruit clusters frequently measure 5 and 6 inches, and average over $41 / 2$ inches in length. It has a naked stem which attaches the cluster to the wood and allows the fruit to be readily picked. It is superior in quality, rich in flavor and much less acid than old sorts. $30 \mathrm{ceach}$.

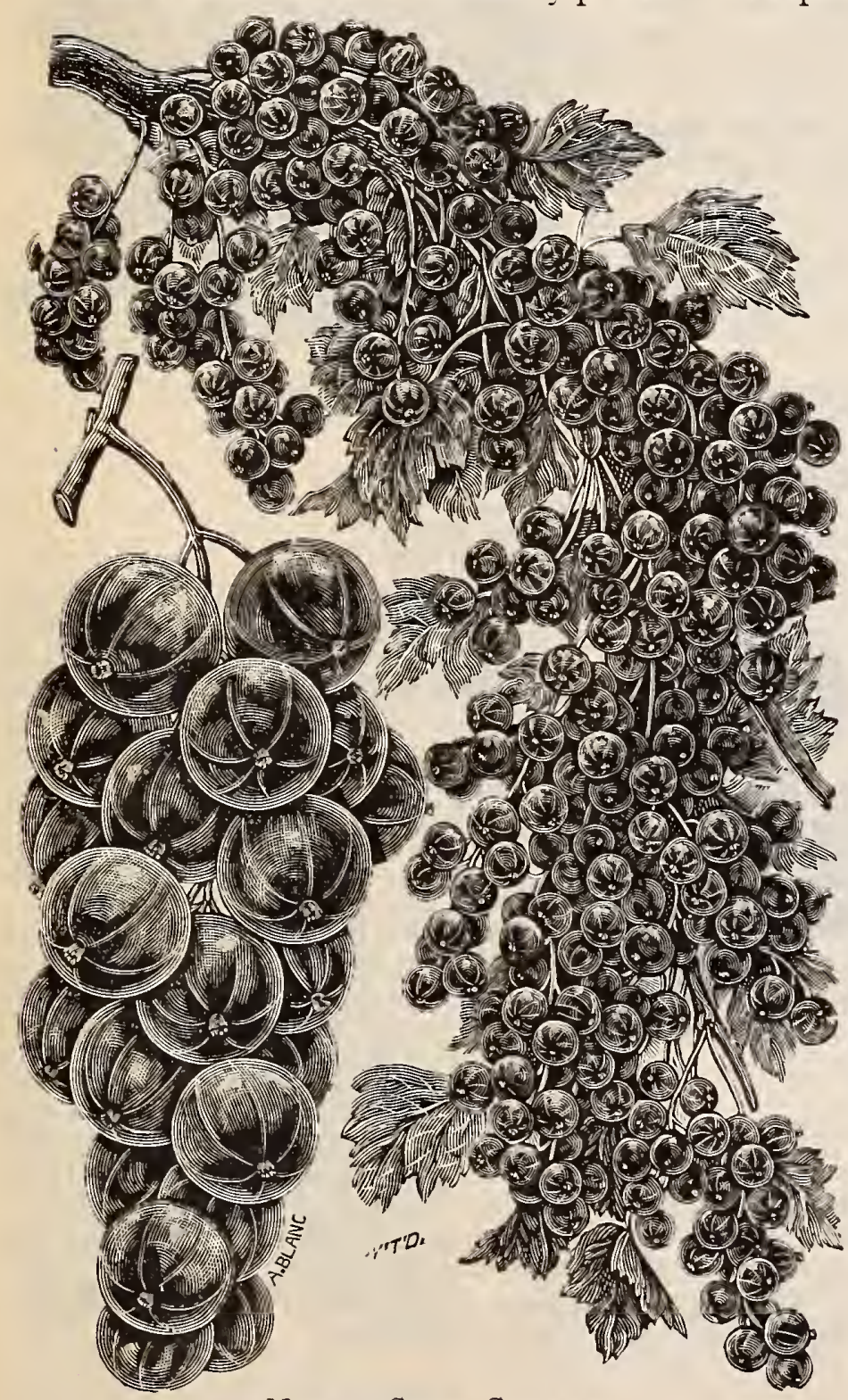

White Grape. Very large; yellowish white; sweet or very mild acid; excellent quality; valuable for table; finest of white sorts; very distinct from White Dutch, having a low spreading habit and dark green foliage Very productive. Price 25 c each.

Lee's Prolific. The best black currant for all purposes. Early, large and productive. Quality splendid. It is as sweet as a huckleberry, and much like it. Price, $25 \mathrm{c}$ each.

Well-known varieties: Improved Red Dutch, Cherry, Victoria, Naples (black). Price, $25 \mathrm{c}$ each.

New Varieties: Crandall (black), Fays, White Gondoin, Long Bunch Holland. Price, $30 \mathrm{c}$ each.

\section{RASPBERRIES.}

This popular berry coming just after strawberries, is welcome to fill out the berry season before blackberries ripen.

\section{RED VARIETIES.}

Varieties priced at $\$ 1.00$ per doz. are $\$ 5.00$ per 100 Varieties priced at $\$ 1.50$ per doz, are $\$ 6.00$ per 100 . Cuthbert. A variety of the greatest excellence, and one of the new kinds that may be pronounced perfectly hardy. The canes are tall and vigorous and enormously productive. Berries very large, conical, rich crimson, very handsome, and so firm that they can be shipped hundreds of miles by railway without injury; flavor ricli; luscious, best; conmences to ripen moderately early and holds on until all others are gone. Price, $25 \mathrm{c}$ each, $\$ 1.00$ per doz.

Shaffer's Colossal. One of the best red berries for family use; unequalled for canning; flavor rich and sprightly. The bush is a strong grower, and entirely hardy; does not "sucker" or sprout from the roots like other red varieties, but propagates from "tips," like the black caps. This variety is wonderfully prolific; has yielded 100 bushels per acre for several years in succession. Price, 30 c each; 1.50 per doz.

Marlboro, Clark, Turner, Hansel. Price 25c each; $\$ 1.00$ per doz.

Brandywine, Golden Queen, Japan Wineberry. Price, $30 \mathrm{c}$ each; $\$ 1.50$ per doz.

The Loudon. This new red raspberry is without doubt the largest, most productive and best of the red varieties. No new berry has been so universally approved by all who have tested it. We have not seen a word from anyone except in praise of its good qualities. It has proven perfectly hardy, a wonderful bearer, a good firm market berry and of excellent flavor. Price, 50c each; $\$ \mathbf{3 . 0 0}$ per doz.; $\$ 20.00$ per 100 .

Minnesota. We, the committee of the Wisconsin State Horticultural Society, and of the Minnesota State Horticultural Society, certify that we have this 12 th day of July, 1895, visited and carefully exanined the raspberry plantations upon the ground of $\mathrm{F}$. IV. Loudon, Janesville, IVis., and freely certify that the new seedling variety originated by him in the year 1880 , and bearing his name, is the most promising variety of red raspberry that we have ever seen for productiveness, size, quality, flavor, firmness of fruit and hardiness, vigor and health of plant.

"We believe that it is the finest Red Raspberry that has yet been introduced."-THE STORRS \& HARRISON Co., Ohio, July 31, 1895.

Michigan. R. Morril1, President of the Michigan State Horticultural Society, wrote: "I expect to plant 20 acres of Loudonl raspberries, believing it to be ahead of all others for market." He saw it in Wisconsin and is growing it heavily for fruit now.

Canada. Loudon raspberry is a strong, healthy grower. It is going to lead in productiveness aud shipping qualities, being firm and of bright red color.-MORRIS, STONE \& WELLINGTON.

The Canada planters are particularly irterested in the hardiness of the Loudon. They have increased their plantations this year and last, which is a pretty good indication that they are satisfied with its behavior.

"The North Star Currants" that I set for myself are all gruwing and most of them have blossoned. bushes. 


\section{BLACK CAPS.}

Varieties priced $\$ 1.50$ per doz. are $\$ 6.00$ per 100 .

Varieties priced $\$ 2.50$ per doz. are $\$ 10.00$ per 100 .

Cumberland, "The New Business Black Cap." This new Raspberry is placed on the market after haring been thoroughly tried. We now offer it with the full assurance that it is the most profitable and desirable market variety ret known, because of its immense size, firmness and great productiveness, well entitling it to the above designation of the "Business Black-Cap." The Cumberland has stood beside the Gregg, Cuthbert, Shaffers, etc., unprotected and came out uninjured. In productiveness it equals the best of the Black-Caps, while the size of the fruit is simply enormous, $3 / 4$ to $7 / 8$ of an inch in diameter frequently, and in quality it is fully equal to the Gregg. The berries are very firm and well adapted to shipping. The fruit ripens just before the Gregg. Price, 30 c each; $\$ 3.00$ per doz.; $\$ 15.00$ per 100 .

Gregg. A hardy black cap; one of the best market Raspberries grown. Very productive-the yield under good cultivation is enormous. Berries very large, covered with a whitish bloom; quality good; firm in shipping. $25 \mathrm{c}$ each; $\$ 1.50$ per doz.

Nemaha. Originated by Hon. Rob't Furnas of Nebraska. Has been well tested on our experimental grounds, and we recommend it. For hardiness, strength and growth of cane, productiveness, size and quality of fruit, it is unsurpassed. The berry is large, black and firm. It is doubtful if a better berry can be found. Price, 25 c each; $\$ 2.50$ per doz.

Winona. A large desirable new variety; fine grower and hardy; fruit buds close together; heary bearer. Price, $25 \mathrm{c}$ each; $\mathbf{\$ 2 . 5 0}$ per doz.

Doolittle, Ada. Price, 25 c each; $\$ 1.50$ per doz.

Johnson's Sweet, Earhart, Eureka, Palmer, 25 cach; $\$ 2.50$ per doz.

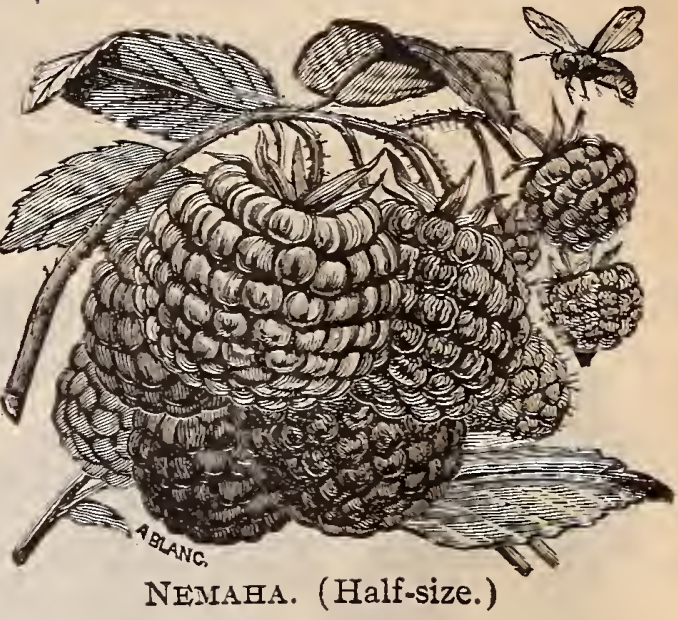

\section{BLACKBERRIES.}

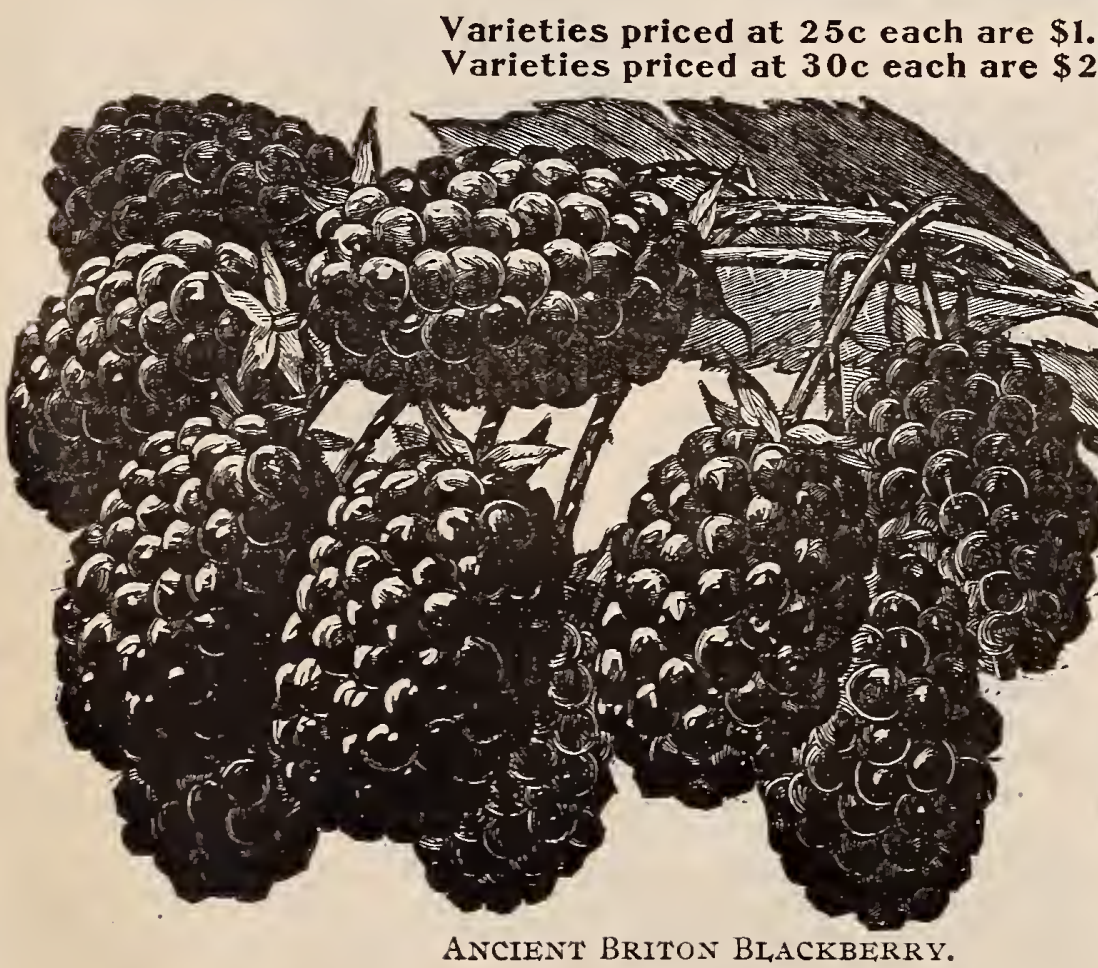

DEWBERRIES.

Price, $25 \mathrm{c}$ each; $\$ 2.00$ per doz.; $\$ 10.00$ per 100 .

The Dewberry, as one of our small fruits, is demanding considerable attention from our fruit growers. Coming along, as it does, between the Raspberries and Blackberries, it is of great value.

Lucretia, Windom. The former of superb quality and very productive.

\section{IMPROVED DWARF JUNEBERRY.}

One of the most valuable berries, and should be planted on every farm in the West. Its leaves are dark, glossy green, and very much resemble the Pear. The fruit is borne in clusters, like the Currant, and ripens in June. Its size equals the wild Gooseberry; shape round; color a reddish purple at first and becomes a bluish black when fully ripened. It may be served with sugar and cream, or cooked as sauce, and is splendid canned for winter use. It produces fruit in enormous quantities and bears every year. It is also perfectly hardy, and needs no special treatment. Rabbits do not injure it. Set the plants 4 by 6 feet apart. Price, 25 c each; $\$ 2.50$ per doz.

\section{ASPARAGUS.}

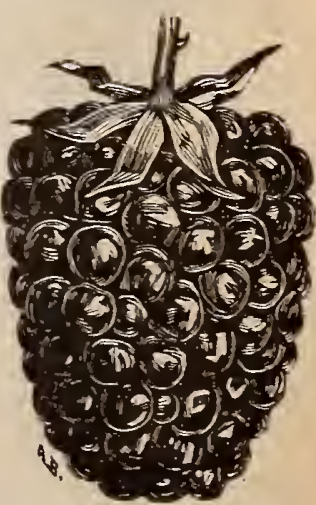

WINDOM DEWBERRY.

Barr's Mammoth, Conover's Colossal, Palmetto. Reliable sorts. Price, $\$ 2.00$ per doz.; $\$ 5.00$ per 100 . RHUBARB.

Victoria, Excelsior, Linnaeus. Every home garden should have some Rhubarb. Price, 25 c each; $\$ 2.50$ per doz. 


\section{A Rule to Find the Number of Plants Required for an Acre.}

The number of square feet in an acre is 43,560 . Divide this amount by the number of square feet required for each plant. Thus, to find how many Currants are required for an acre planted 4 feet by 6 feet, 6 times 4 equals 24 ; 43,560 divided by 24 equals 1,815 -the number required for an acre.

In Minnesota fruit trees do not grow to be as large as in the Southern and Eastern States, and experience shows that it is better to plant them near to each other, and then thin them out when they are too thick. We have adopted the distances here give11, but in Southern locations it will be best to set farther apart:

Plums, Cherries, Pears and Peaches, 16 by 16 feet........... $170 \mid$ Raspberries, red and black, 3 by 6 feet 2,420 Apples, 20 by 20 feet........................................... 109

Strawberries, 1 by 4 feet............................................10,890

Grapes, 8 by 8 feet.

Blackberries, 4 by 6 feet.................................................. 1,815

Dewberries, 3 by 6 feet....................................... 2,420

Juneberries, 4 by 6 feet............................................ 1,815

Rhubarb, 3 by 6 feet ........... 2,420

Gooseberries, 4 by 6 feet..................

Currants, 4 by 6 feet.

Asparagus, 2 by 2 feet.

10,890

\section{TIMBER=CLAIM SEEDLINGS.}

\section{PRICES ON APPLICATION.}

A large and growing demand for trees for timber claims exists on the treeless prairies. We are prepared to meet this demand in a satisiactory manner. The following are the most hardy and desirable:

Ash, Box Elder, Butternut, Cottonwood, Elm, Hard Maple, Soft Maple, Walnut, White or Gray Willow.

\section{SHADE AND ORNATENTAL TREES.}

Varieties priced at $50 \mathrm{c}$ each are $\$ 5.00$ per dozen; $\$ 35.00$ per 100 .

Varieties priced at $75 \mathrm{c}$ each are $\$ 7.50$ per dozen; $\$ 50.00$ per 100.

Varieties priced at $\$ 1.00$ each are $\$ 10.00$ per dozen.

Landscape Architecture. We have made a careful study of this subject and are prepared to advise those desiring to improve their home grounds, free of charge. An intelligent selection of varieties, with an artistic arrangement, will give you the best effects at the lowest possible cost. By consulting us you may avoid expensive errors. Advice and information FREE. Plans, estimates and designs furnished at cost.

We carry a full assortment of larger sized trees for parks, etc., and will make special prices on application. Write us.

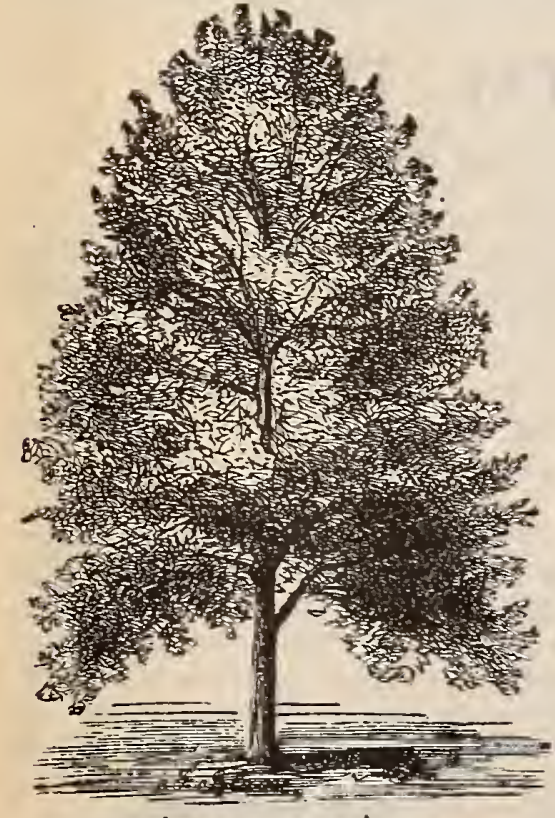

AMERICAN ASH.

American Black Ash. ( $F$. var. Sambucifolia.) 6 to 8 feet. Price 50c eaeh.

Green Ash. ( $F$. Varidis.) A fine tree for general planting. It is a native of Minnesota and seeds very freely. 6 to 8 feet. Price, $50 \mathrm{c}$ each.

White Ash. (F. Americana.) 6 to 8 feet. Price, 50c each.

\section{BASSWOOD.-(See Linden.)}

BIRCH.-(Betula.)

American White Birch. (B. populifolia.) An American species of rapid growth, with triangular, taper-pointed, smooth and glossy leaves. 6 to 8 feet. Price, $50 \mathrm{c}$ each.

European White Birch. (B. Alba.) A graceful tree of moderate size. with silvery bark and slender branches, quite erect when young, but after four or five years of growth it assumes an elegant drooping habit, very effective in land scapes. 6 to 8 feet. Price, $75 \mathrm{c}$ each.

Paper or Canoe Birch. (B. Papyracea.) 6 to 8 feet. Price, $75 \mathrm{c} \mathrm{each.}$

BOX ELDER or Ash Leaved Maple. (Acer negundo.) A native tree, maple-like in its seed, and ash-like in its foliage; of irregular, spreading habit and rapid growth. 6 to 8 feet. Price, $50 \mathrm{c}$ each.

BUFFALO BERRY. (Sheperdia argentea.) As a hardy tree there is nothing superior. It is fine for ornamental purposes and also for hedging. It is the latest tree to hold its fruit and it keeps its leaf until late, and is valuable on that account. It bears cutting well. It is independent of drought and bears abundantly, being well adapted to a dry climate. It seems to be at home in the arid regions of Dakota. The fruit, though small is quite good in flavor, similar to the cranberry. It makes nice jelly. 3 to 4 feet. Price, 50c each.

CATALPA. (Catalpa speciosa.) 5 to 6 feet. Price, $\$ 1.00$ each.

CHESTNUT-American Sweet. (Castanea Americana.) 4 to 5 feet. Price, $75 \mathrm{c}$ each.

COFFEE TREE. (Gymnocladus Canadensis.) 6 to 8 feet. Price, $75 \mathrm{c}$ each.

DOGWOOD, White Flowering. (Cornus Florida.) 4to 5 feet. Price, $\$ 1.00$ each.

$$
\text { ELM.-(U1mus.) }
$$

American White Elm. ( $U$. Americana.) This is the noble, spreading and drooping tree of our own forests, than which there is no finer tree for street and park planting. 6 to 8 feet. Price, $50 \mathrm{c}$ each.

Nettle-Leaved EIm. 5 to 6 feet. Price, $75 \mathrm{c}$ each.

Red, or Slippery Elm. 6 to 8 feet. Price, $50 \mathrm{c}$ each.

HACKBERRY, or Nettle Tree. 5 to 6 feet. Price, $75 \mathrm{c}$ each.
HORNBEAM. (Catpinus A.) 4 to 6 feet. Price, 75c each. HORSE CHESTNUT. 4 to 6 feet. Price, $\$ 1.00$ each.

LARCH, European. (Larix Eu.) 2 to 3 feet. $\$ 1.00$ each.

$$
\text { LINDEN, OR LIME TREE.-(Tilia.) }
$$

American Linden, or Basswood. ( $T$. Americana.) A rapid growing, large sized beautiful native tree, with large leaves and fragrant flowers. 6 to 8 feet. Price, $75 \mathrm{c}$ each.

European Linden. ( $T$. Europæa.) 6 to 8 feet. Price, $75 \mathrm{c}$ each.

\section{LOCUST, OR ACACIA.-(Robinia.)}

Moss Locust, or Rose Acacia. ( $R$. hispida.) 4 to 5 teet. Price, $75 \mathrm{c}$ each.

Yellow or Black Locust. ( $R$. pseudo-acacia.) 5 to 6 feet. Price, $75 \mathrm{c}$ each. 


\section{ORNAMENTAL DEPARTMENT.-CONTINUED.}

\section{MAPLE- $-($ Acer. $)$}

European Sycamore Maple. (A. pseudo-platanus.) 6 to 8 feet. Price, $\$ 1.00$ each.

Norway Maple. (A.platanoides.) 6 to 8 feet. Price, $75 \mathrm{c}$ each.

Sugar or Rock Maple. 6 to 8 feet. Price, $75 \mathrm{c}$ each.

Soft or Silver Leaved Maple. (A. dasycarpum, or eriocarpum.) A North American species of rapid growth, large size and irregularly rounded form. Foliage bright green above and silvery white beneath. Tree very hardy and easily transplanted. One of the most useful trees where immediate shade is required; also a favorite street and park tree. 6 to 8 feet. Price, $50 \mathrm{c}$ each.

MAIDEN HAIR TREE, or Ginkgo. (Salisburia.) 5 to 6 feet. Price, $\$ 1.00$ each.

\section{MOUNTAIN ASH.-(Pyrus.)}

American Mountain Ash.- ( $P$. Americana.) A tree of coarser growth and foliage than the European, and producing larger and lighter colored bcrries. 5 to 6 feet, $75 \mathrm{c}$ each.

European Mountain Ash. ( $P$. ancuparia.) A fine hardy tree; head dense and recular, covered from July until winter with great clusters of bright scarlet berries. 5 to 6 feet. Price, $75 \mathrm{c}$ each.

Oak-Leaved Mountain Ash. ( $P$.var.quercifolia.) A hardy tree of fine pyramidal habit. Height from 20 to 30 feet. . Foliage deeply lobed; bright green above and downy beneath. One of the finest lawn trees. Price, $\$ 1.00$.

RUSSIAN MULBERRY. 5 to 6 feet. Price, $50 \mathrm{c}$ each.

RUSSIAN OLIVE. 4 to 5 feet. Price, $\$ 1.00$ each.

$$
\text { OAK.-(Quercus.) }
$$

American White Oak. (Q. Alba.) 5 to 6 feet. $\$ 1.00$ each. Black Oak. (Q.c. var. tinctoria.) 5 to 6 feet. $\$ 1.00$ each.
Burr Oak, or Mossy Cup Oak. (Q. macrocarpa.) 5 to 6 feet. Price, $\$ 1.00$ each.

Chestnut-Leaved Oak. ( $Q$.prinos.) 5 to 6 feet. Price, $\$ 1.50$ each.

Red Oak. (Q. rubra.) 5 to 6 feet. Price, $\$ 1.00$ each.

Scarlet Oak. (Q. coccinea.) 4 to 5 feet. $\$ 1.50$ each.

OSAGE ORANGE. (Maclura aur.) 4 to 6 feet. 50c each. POPLAR.-(Populus.)

Balm of Gilead. ( $P$. Bal. cand.) 6 to 8 feet. $50 \mathrm{c} \mathrm{each.}$ Cottonwood Poplar. 6 to 8 feet. Price, $50 \mathrm{c}$ each. Dudley Poplar. ( $P$. Dudleyi.) 5 to 6 feet. $75 \mathrm{c}$ each. Laurel-Leaved Poplar. 5 to 6 teet. Price, 50c each. Lombardy Popular. 6 to 8 feet. Price, $50 \mathrm{c}$ each.

$P$. Centinensis. 6 to 8 feet. Price, 50c each.

$P$. a rar. Bolleana. 6 to 8 feet. Price, $50 \mathrm{c}$ each.

Wabsky Poplar. 6 to 8 feet. Price, 50c each.

White, or Silver Poplar. 6 to 8 feet. Price, 50 c each. WALNUT.-(Tuglans.)

Black Walnut. ( $J$. nigra.) A native species of great size and majestic habit. Bark very dark and deeply furrowed; foliage beautiful, each leaf being composed of from 13 to 17 leaflets; nut round; valuable for fruit and for timber. 6 to 8 feet. Price, $75 \mathrm{c}$ each.

Butternut. ( $J$. cinerea.) 6 to 8 feet. Price, $75 \mathrm{c}$ each. WILLOW.-(Salix.)

American White Willow. 6 to 8 feet. Price, 50c each. Golden Willow. 6 to 8 feet. Price, $75 \mathrm{c}$.

Rosemary Willow. 5 to 7 feet. Price, $75 \mathrm{c}$ each. Russian Willow. 6 to 8 feet. Price, $50 \mathrm{c}$ each.

Russian Golden Willow. 5 to 7 feet. Price, $75 \mathrm{c}$ each. Russian Laurel-Leaved Willow. 6 to 8 feet. $75 \mathrm{c}$ each. Red Willow. (S. fragilis.) 5 to 6 feet. Price, 50c each.

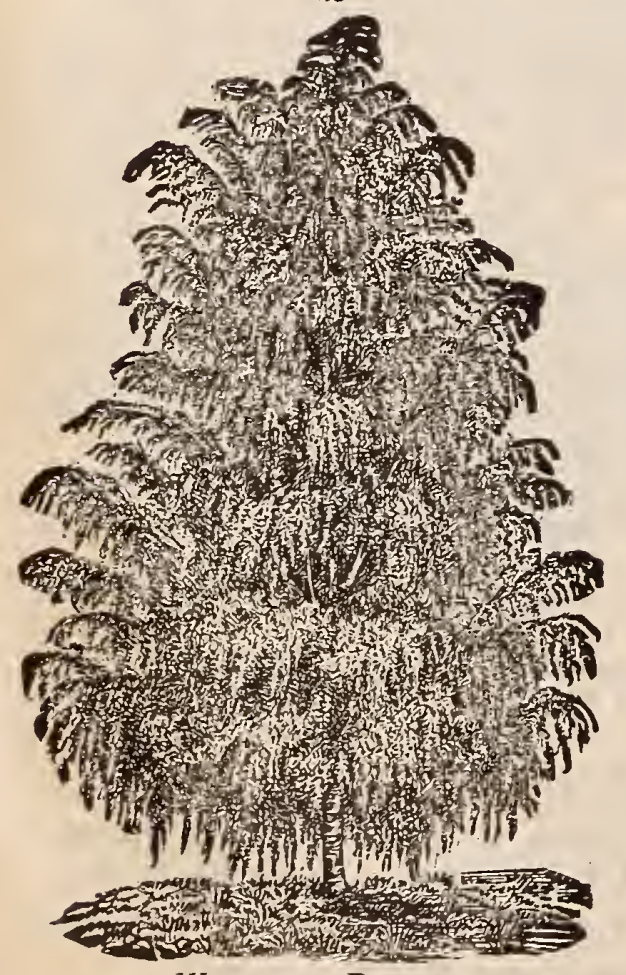

IVEEPING BIRCH.

\section{WEEPING ORNAMENTAL TREES.}

\section{Varieties priced at $\$ 1.50, \$ 12.00$ per dozen.}

CUT-LEAVED WEEPING BIRCH. (Betula pendula laciniata.) Beyond question one of the most popular of weeping or pendulous trees. Its tall, slender, yet vigorous growth, gracefully drooping branches, silvery white bark and delicately cut foliage present a combination of attractive characteristics rarely met with in a single tree. 5 to 6 feet. Price, $\$ 1.50$ each.

Weeping EIm.-(Ulmas var. pendula.) A variety of luxuriant growth and elegant drooping habit. Its branches shoot upward at first, then bend in graceful curves toward the ground. It also retains the foliage much longer than other Elms. (See back cover.) 5 to 6 feet. Price, $\$ 1.50$ each.

WIER'S CUT LEAVED SILVER MAPLE. (Acer dasycarpum Weirii laciniatum.) A variety of the silver-leaved, and one of the most remarkable and beautiful trees, with cut or dissected foliage. Its growth is rapid, shoots slender and drooping, giving it a habit almost as graceful as the Cut-Leaved Birch. The foliage is abundant, silvery white underneath, and, on the young wood especially, deeply and delicately cut. The leaf stalks are long, and tinted with red on the upper surface. It ranks among the most interesting and attractive lawn trees, and may easily be adapted to small places by an occasional cutting back, which it will bear to any degree necessary, as well as a willow. 5 to $6 \mathrm{ft}$. $\$ 1.50$ each.

WEEPING EUROPEAN MOUNTAIN ASH. (Pyrus aucuparia var. pendula.) A beautiful variety of rapid growth and decidedlv pendulous and trailing habit. A most desirable lawn tree. Price, $\$ 1.50$ each

KILMARNOCK WEEPING WILLOW.(Salix caprea var. pendula.) A variety of the Goat Willow, or common Sallow. Grafted 5 to 7 feet high upon the Comewell stock, it forms, without any trimming, an exceedingly graceful tree with glossy foliage and perfect umbrella head; unique in form. Vigorous and thriving in all soils, it is probably more widely disseminated than anv of the finer ornamental trees. 5 to 7 feet. Price, $\$ 1.50$ each.

WISCONSIN WEEPING WILLOW. Of drooping habit. Valuable on account of its ability to resist severe cold. 5 to 6 feet. Price, $50 \mathrm{c}$ each.

WEEPING TOOTH-LEAVED POPLAR. (Popusus.) Of rapid growth, with long, slender branches, drooping gracefullv to the ground. Foliage large and deeply serrated. 5 to 6 feet. Price, $\$ 1,50$ each.

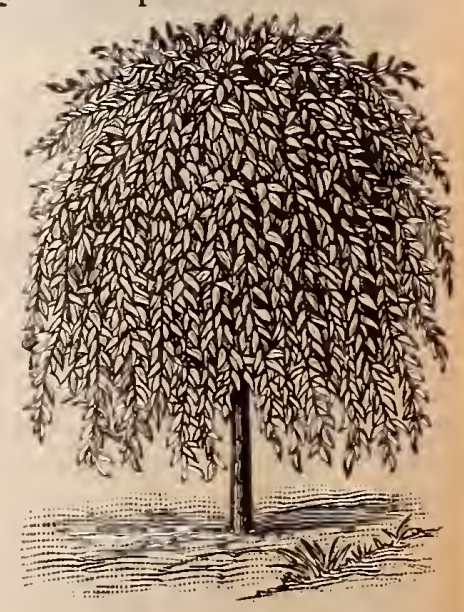

KILMARNOCK WILLOW. 

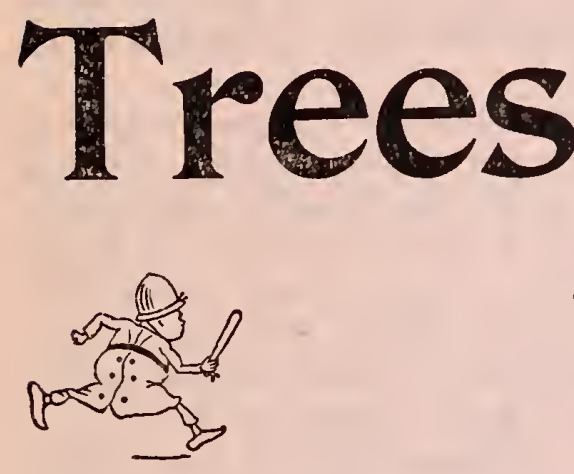

...that...
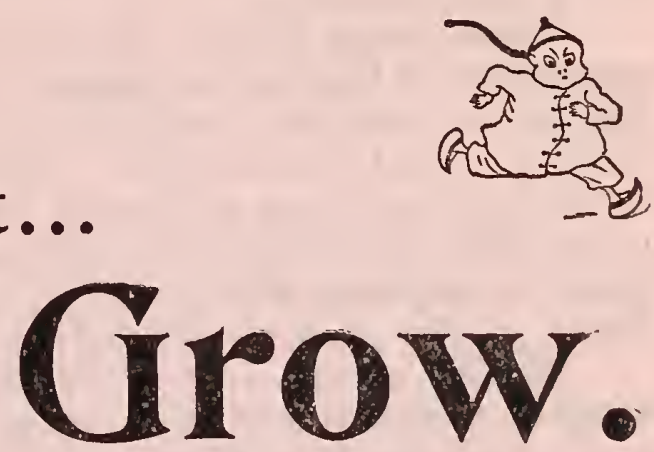

Fine Fruits come from the best trees, and the best trees come from the Northern growers. We are the most northerly nursery in the United States. The very best trees in the United States come from our great nursery at Lake City, Minn.,-absolutely the best and hardiest trees that can be bought with money. Nobody, at any price can sell you as good trees as we can at a low price.

Fine fruits come from the very best Northern=grown trees. Why? Because there are no other trees so vigorous in growth, so hardy to resist cold winters and so early in bearing fruit, and because we have short seasons of growth, a perfect ripening of the wood and a long season of rest to store up vitality. Who are the strung, healthy, vigorous men? The North men. What is trie of men is true of trees.

We grow all the trees recommended by the very best horticultural authorities, and we warrant our stock true to name and exactly as we represent, or we will either return your money, or send you other goods.

The important thing to remember is that our trees grow and trees that grow will certainly bear fruit.

We have ready for shipment at short notice:

100,000 Apple Trees.- First-class two and three year old trees, 5 to 7 feet, hardy and well ripened up. Varieties selected to resist severe cold and drouth.

25,000 Plum Trees.-On native plum roots. These consist of the very best selection of American and foreign varieties. We have a complete assortment.

15,000 Cherry, Peach, Apricot.-We carry a good supply of the hardiest varieties, and can make up a list suited to your locality, if you are not too far not but Pears, Peaches and Apricots are too tender to stand our winters.

"Five years ago I purchased of your agent some nursery stock. The first lot was some apples, plums and smail fruits, amounting to about $\$ 20$. The next year I bought some more. This bill consisted mostly of apple and cherry trees and 500 grapes, and I have never had occasion to regret it yet. "Your truit trees are the best in my neighborhood and for miles around. They would have astonisned the peoplc as they passed by, as I bad to prop up some of the limbs to keep them trcas? breaking unmrn. FRED GOODSMLA:"." 
EAGLE GRote, Iowa, May i, 1897.

"Inclosed please find draft for $\$ 11^{7}, 75$ and your Mr. Carder's receipt for $\$ 20$, same being pay. ment in full for trees purchased of you by the Eagle Grove Park Commissioners, and will add that the Park Commissioners are highly pleased with the trees furnished by you and with the treatment received at your hands. A. N. OLdenteiser, Secretary Park Commissioners.

100,000 Evergreens.-Consisting of Arbor Vitæ, Balsam Fir, Cedars, Pines, Spruces, Junipers, etc., etc. These hare all been transplanted from one to three times, and root-pruned in such a manner as to insure their growth. Do not plant evergreens larger than two feet high. Always plant them in the spring.

55,000 Grape Vines.- We grow as fine Grape Vines here as can be grown anywhere in the United States. We have a large stock suitable for the Northwest, and also a complete assortment of all the leading varieties, with many new and choice kinds. You can grow good grapes and lots of them in Minnesota, if you will select the right varieties, give them reasonable care, a fair amount of labor and not much expense. They will be far superior to any imported fruit you can buy, and will not cost half as much. Make an effort and we will help you. Plants by mail, express or freight.

80,000 Currants.-Of which 20,000 are our famous "North Star," the largest, sweetest and best red currant grown. We have a large assortment of all the Red, White and Black varieties in one and two year grades, that are extra fine plants, well branched and rooted, by mail, express or freight. None better anywhere.

50,000 Gooseberries.-Chiefly American, Downing, Houghton, Transparent, Industry and Red Jacket. One and two year choice plants, trimmed ready for planting.

75,000 Raspberries, 20,000 Blackberries, 15,000 Dewberries.-These include all the standard varieties, and the choicest of the new kinds. Erery plant guaranteed first-class.

15,000 Roses.--Consisting of hardy out-door varieties that need littlo or no protection, and a fine selection of Greenhouse, Climbing and Mloss Roses. Our houses are new and our stock is free from insects or disease.

50,000 Ornamental Shrubs. - Consisting of Hydrangeas, Honeysuckles, Snowballs, Lilacs, Spireas, Syringas, etc., and a large collection of Herbaceous Shrubs, Vines, etc. Ask us for what you want. We will supply it if it will grow in this country.

125,000 Shade and Ornamental Trees.-From 6 to 20 feet in height and from $\frac{1}{2}$ inch to 3 inches in diameter; by freight or express only.

2,000,000 Timber Claim Seedlings.-One and two years old, nursery grown, guaranteed full count and in perfect condition for planting. We have Ash, Box Elder, Cottonwood, Ėlm, Maple, Russian Mulberry, Walnut, $W$ illow, etc., and we guarantee them first-class. By mail, express or freight.

In addition to the above, we have an immense stock of bulbs and tubers, Gladiolous, Dahlias, Pæonies, and hardy out-door flowering plants, shrubs, vines and house plants. We also have three new greenhouses well stocked with Roses, Carnations, Chrysanthemums, Begonias, Fuchsias, Geraniums, Palms, Ferns and a full line of greenhouse flowering, ornamental, foliage and bedding plants in mail order sizes, and in large potted plants, suitable for express or freight. Our greenhouses are all new, and our stock is fresh and free from the diseases and insect enemies so common in old houses that have been in use for years. With our plants you will not have a constant fight to keep them alive, but your care and attention will be rewarded with abundant success. 
BozgMAN, Mont., July 3, 189\%

"Mrs. Yerkes received her plants to-day, and to $a y$ that she is delighted would be mild. Our experience and that of others in this valley has $b$ an so widely different from the treatment we have received at your hands, that it is a matter of sumething more than favorable comment on the part of ourselves and friends. In view of this I take the liberty of writing you our thans and stand ready to recommend you to my friends.

A. K. YERKES, Editor Chronicle."

It is our constant study to select and grow varieties that are adapted to this severe climate. This requires hardy, vigorous trees and plants in which the vitality or life principle is strongly developed. Our next consideration is the quality of the fruit and its habit of ripening early, so as to be out of the way of the fall frosts. When we have secured these we study how to grow them successfully. The soil, cultivation and treatment of apple trees, plum trees and small fruits particularly, are given the closest attention.

Many years' experience in business has given us a fund of information that we know is valuable, and we now request you to let us share this knowledge with you. If you want to grow an orchard we ought to be able to give you valuable advice. If you want a perfect small fruit garden, we can help you in its selection and care. Again, if you desire to plant flowers or shrubs or ornament your lawn, we can tell you much that will save you loss of time and money, and we charge you nothing for this.

In addition to this, we can supply you with the best, the very best and hardiest trees, plants, shrubs, small fruits, etc., at a fair and reasonable price.

Which shall it be, trees bought anywhere that you HOPE will grow, or trees bought of us, that you KNOW will grow. We know it will cost you less to buy the best trees of us, rather than to buy the "next best" of some one else. We do not want to sell a single tree or plant unless we feel absolutely certain that it will grow. We want our reputation to grow up with each tree, shrub and vine that leaves our nursery. If you buy cheap trees, you get trouble, care and disappointment, but if you give us your order, we will select for you choice stock that is clean, healthy and vigorous. In fact, we will send you goods that will repay you for the best care and attention you may give them, and we hope that every tree, plant or vine we may send you will prove so satisfactory that you will tell your friends, and thus secure us more customers.

SEND US YOUR ORDERS. Large or small, they will receive the same careful attention, and we will do our utmost to make your dealing with us satisfactory. We want your trade. and when we get it we are going to treat you so that we may keep it. ORDER NOW.

Respectfully yours,

\section{The Jewell Nursery Co.}

"T KuLswortH, Iowa, May 7, 1897. Trees preceived your trees the 4th of May and must say they were packed in first-class shape. ready commenced to leave out and show that they are going to live. P. E. EGLAND.

Noxow, Mont., Oct. $4,1596$.

"The trees I got from you last spring all did flnely and look twice as well as the trees from the west. A number of people have looked at your trees and asked what I have been doing to them to make them look so well.

A. C. NOTTINGEAM,

Aberdeex, S.' D., March 19, $189 \%$.

"The apple trees that I got of you a couple of years ago for my farm ai St. Charles, Mrinn., \&re doing splendidly.

J. G. ZimMERIIANN.

WILLIAMSBDRG, Iowa.
The trees I received from you were the flnest I ever received from any nursery. The stock was all alive, thrifty and vigorous. I heartily recommend your Northern-grown trees and advise my neighbors to get their suppls from you. ЈонN J. YATES." 


\section{THE MINNESOTA STATE HORTICULTURAL SOCIETY}

ecommends the following rarieties for the Northwest. This list may be regarded as nearly perfect as it is possible to make one. It is the result of the combined experience of the largest fruit growers of the State, the active nurserymen of Minnesota, and the State Experimental Corps, who were present and took an active part in the discussion and its selection.

It is the formal recommendation of the Minnesota State Horticultural Society of the rarieties best adapted to cultivation in the Northwest.

\section{APPLES.}

Of the first degree of hardinessfor planting in Minnesota - Duchess, Hibernal, Charlemoff.

of the second degree of hardiness-Tetofsks, Wealthy, Longfield, Malinda.

Promising rarieties for trial-Patten's Greening, Okabena, Anisim, etc.

Best Crabs and Hybrids ior cultiration-Virginia, Martha, Whitney, Early Strawberry, Minnesota, Sweet Russett, Gideon No. 6, Brair Sweet, Tonka.

\section{PLUMS.}

Best for general eultiration-De Soto, Forest Garden, Weever, Cheney, Wolf, Rollingstone.

\section{GRAPES.}

Concord, Delaware, Moore's Early, Worden, Agawam, Brighton, Janesville.

\section{RASPBERRIES.}

Red rarieties-Marlboro, Cuthbert, Turner, Brandywine.

Black and purple varieties-Ohio, Palmer, Nemaba, Gregg, Schaffer, Older, Souhegan.

\section{BLACKBERRIES.}

Ancient Briton, Snyder, Badger.

\section{CURRANTS.}

Red Dutch, White Grape, Victoria, Long Bunch Holland, Stewart, North Star.

\section{STRAWBERRIES.}

Pistillates-Crescent, Marfieid, Harerland.

Staninates-Bederwood, Capt Jack, Wilson, Enhance, Lorett.

Faluable natire froits for trial-D warf Juneberry, Sand Cherry.

The abore is the complete list recommended for general planting. We omit some varieties recommended for trial, as their ralue in this climate is not yet determined.

We can supply any of this list. Tell us what you want and we will make low prices for good goods that grom.

\section{The Jewell Nursery Co.,}

LAKE CITY, MINNESOTA.

I receired the stock I ordered and I am so rell pleased with the trees and your courteous treatment that I feel it my duty to acknowleage the same. I hare bought orer $\$ 300$ worth of nur sery stock in the past tro years and that I got from you is ine best I erer saw.

J Aries PRINCE, Mineral Point, Wis.

Enclosed find check for $\$ 14.90$. The trees and plants are sery satisfactory and we write to thank you for the nice quality and good condition of the same.

J. F. Patton \& Co., Milwaukee, Wis. 


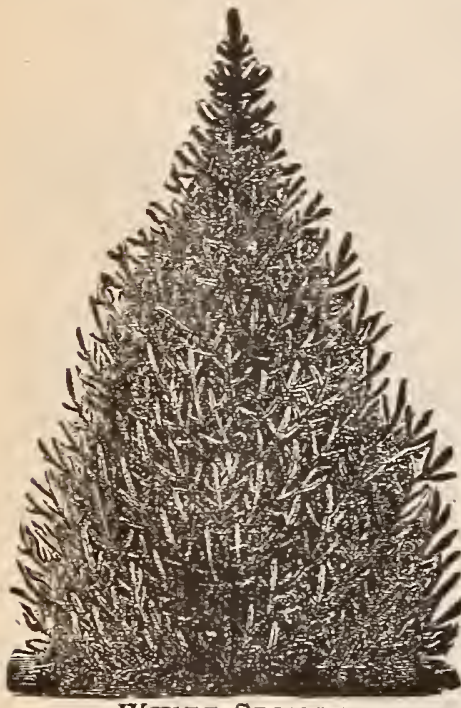

WHITE SPRUCE.

\section{EVERGREENS.}

Nursery-grown Evergreens transplant as easily as any class of trees. Young trees, or those of moderate or small size, are the most certain and profitable to remove. Thorough culture and mulching are very useful especially in dry seasons. Early spring planting we have found the best, but they can safely be removed in wet seasons quite late, or until the new shoots are started. In planting, tramp the earth firmly (but carefully) on the roots, the importance of this can scarcely be overstated. In transplanting, the roots should never be exposed to the sun and air a single minute. Evergreens are superb for screens or wind-breaks around buildings, orchards and stock corrals. Norway Spruce, White and Scotch Pine, Red Cedar and Arbor Vitæ, are all admirable for that purpose. The last two for low screens should be planted 18 inches apart, and clipped twice each year while young, in June and August. For high screens plant two or more rows, 10 to 12 feet apart, 12 feet in the row, each tree opposite the center of the space in the next row. Evergreens should be allowed to branch out near the ground. Pruning can be done before they start in the spring, and to thicken up Evergreens rapidly, clip off the ends of the young, succulent shoots while they are soft and tender.
ARBOR VITAE-American

\begin{tabular}{|c|c|}
\hline $\begin{array}{l}12 \\
1 \text { st size }-12 \text { to } 18 \text { in } \ldots . \ldots \ldots \ldots \ldots . . \$ 2.50 \\
2 d \text { size }-18 \text { to } 24 \text { in } \ldots \ldots \ldots \ldots \ldots .4 .00\end{array}$ & $\begin{array}{c}100 \\
\$ 15.00 \\
25.00\end{array}$ \\
\hline JUNIPER SAVIN & \\
\hline 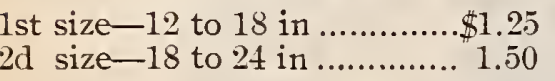 & $\$ 8.00$ \\
\hline
\end{tabular}

\begin{tabular}{|} 
Red Cedar 18 to 24 in... 5.00 \\
PINE-White and Scotch \\
1 st size-12 to 18 in ...........\$2.50 $\$ 15.00$ \\
$2 d$ size-18 to 24 in ............ 4.00 \\
Mountain Dwarf- \\
12 to 18 in................ 6.00
\end{tabular}

\begin{tabular}{|c|c|c|}
\hline SPRUCE-White, Norv & $\mathbf{J}, \mathbf{B}$ & Fr. \\
\hline 1 st $\operatorname{size}-12$ to 18 in & $\$ 2.50$ & $\$ 20.00$ \\
\hline $2 \mathrm{~d}$ size -18 to 24 in ...... & 4.00 & 25.00 \\
\hline Hemlock. 12 to 18 in ..... & 4.00 & \\
\hline Concolor. 10 to $12 \mathrm{in} \mathrm{......}$ & 7.50 & \\
\hline Colorado Blue. 10 to $12 \mathrm{in.}$ & 7.500 & \\
\hline Douglass. 10 to 15 in...... & 7.50 & \\
\hline
\end{tabular}

\section{ARBOR VITAE-(Thuya.)}

American Arbor Vitae. ( $T$. occidentalis.) A native tree knownas White Cedar. Excellent for screen s and he dges, and makesa fine tree on the lawn. Price, 1st size, $25 \mathrm{c}$ each; $2 \mathrm{~d}$ size, $40 \mathrm{c}$ each.

Pyramidal Arbor Vitae. ( $T$. a. var. pyramidalis.) Very upright, same habit as the Irish Juniper; growth very dense, with rich, dark luxuriant foliage; to our fancy far surpassing any of the Juniper family, while its superior hardiness entitles it to a place in every yard and lawn. 18 to 24 inches. Price, $\$ 1.00$ each.

Siberian Arbor Vitae. ( $T$. a. var. Sibirica.) 18 to 24 inches. Price, $\$ 1.00$ each.

\section{JUNIPER.-(Juniperus.)}

Irish Juniper. ( $J$. communis var. Hibernica.) 18 to 24 inches. Price, $75 \mathrm{c}$ each.

Juniper Savin. ( $J$. Sabina.) A dwarf, spreading shrub, with trailing branches. Thrives in the poorest soils. Very suitable for rock work. This is the finest plant for low hedging chat can be found for the Northwest. It is the lowest growing of all the evergreens-never attaining a greater height than 4 or 5 feet. The foliage is of a rich dark green, very fine and compact. It never sunburns or turns brown in the winter. It can be sheared very closely, and kept down low. On this account it is especially desirable for cemetery purposes-as a border for a lot-for here it can be kept very low by close shearing, and simply outlines the lot by a border of living green. It is very easy to make live, as it has many fibrous roots, and with good care given the first vear or two in eultivating or mulching, it will take care of itself after that, and only needs pruning every year to keep it in shape. Experience on our own grounds has demonstrated fully its desirability. As a low evergreen for a small lawn, or a clump or group on large grounds, it is an acquisition, for its rich, dark green gives variety to the lighter color of the other evergreens. (See illustration, page 3 ). Price, 1 st size, $25 \mathrm{c}$ each; $2 \mathrm{~d}$ size, $30 \mathrm{c}$ each. each.

Red Cedar. (J.Virginiana.) 18 to 24 inches. Price, $50 \mathrm{c}$

$$
\text { PINE.-(Pinus.) }
$$

California Pine. (P. Ponderosa.) 12 inches; $\$ 1.50$ each. Mountain Pine. ( $P$. Montana.) A dwarf variety; foliage dense and a rich, dark green, perfectly hardy. Price, 1 st size, $75 \mathrm{c}$ each.

Scotch Pine or Fir. ( $P$. sylvestris.) A native of the British Islands. A fine, robust, rapid growing tree, with stout, erect shoots, and silvery green foliage; very hardy; valuable for shelter. Price, 1st size, 25c each; $2 \mathrm{~d}$ size, $40 \mathrm{c}$ each.

White Pine. (P.strobus.) The most ornamental of all our native Pines; foliage light, delicate, silvery green; flourishes in the poorest of light, sandy soils. Very valuable. Price, 1 st size, 25c each; $2 \mathrm{~d}$ size, $40 \mathrm{c}$ each.

\section{SPRUCE.-(Abies.)}

Balsam Fir. (A. Balsamea.) Price, 1st size, 25c each; 2d size, 40 c, each.

Colorado Blue Spruce. ( $A$. pungens.) 10 to 12 inches. Price, $75 \mathrm{c}$ each.

Douglas Spruce. (A. Douglasii.) 10 to 15 inches. Price, $75 \mathrm{c}$ each.

Hemlock Spruce. (A. Canadensis.) 12 to 18 inches. Price, $40 \mathrm{c}$ each.

Norway Spruce. (A. excelsa.) Price, 1 st size, 25c each; $2 \mathrm{~d}$ size, $40 \mathrm{c}$ each.

White Spruce. (A. alba.) A native tree of medium size, varying in height from 25 to 50 feet; of a pyramidal form; foliage silvery gray and bark light colored; very hardy and valuable. Price, 1st size, 25c each; 2d size, 40c each.

(A. concolor.) 10 to 12 inches. Price, $75 \mathrm{c}$ each.

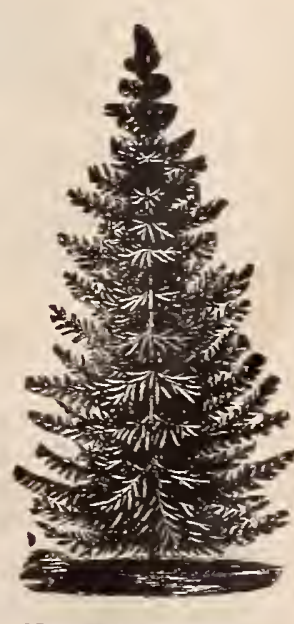

NORTIY SPRUCE

HURLEY, TURNer Co., S. D., May 6, 1897

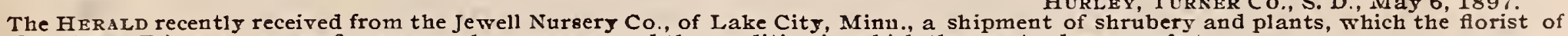
this firm (Mrs. B.) says were as fine as any she ever saw, and the condition in which they arrived was perfect.

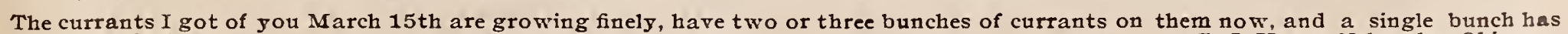
grown twelve inches. 


\section{ORNAMENTAL DECIDUOUS SHRUBS.}

\section{Plants will be 2 to 3 feet high, except where noted.}

A beautiful effect may be produced by planting our hardy shrubs. On large lawns they should be set with the high-growing varieties on the back or in the center and the lower-growing in front or around. The Lilacs (purple and white), with Weigelas and Syringas, make a beautiful group. The Tartarian Honeysuckle (pink and white), and the Hydrangea paniculata grandiflora, which is as hardy as a Snowball, are fine as specimen shrubs for the lawn-handsome when not in flower and always giving very good returns for a little care. The different Spiræas are especially desirable for completing the blooming season.

With regard to pruning shrubs; every plant, tree and shrub has its own habit of growth, and this distinctive feature is its attraction, so do not try to prune them all alike, but simply remove dead branches and try to preserve as nearly as possible the peculiarities of habit and foliage. The Weigelias, Deutzias and Syringas (Mock Orange), flower on the wood of the preceding year's growth, hence these shrubs should not be pruned in the winter or spring, but after they are through flowering, when the old wood should be shortened or cut out, thus promoting the growth of the young wood, which is to flower another year.

Spiræas, Lilacs and Honeysuckles may be trimmed a very little during the winter or early spring, but it is a better rule to trim all shrubs after they are through flowering. The Hydrangea paniculata grandiflora should be severely cut back and trimmed early every spring.

\section{BARBERRY-(Berberis.)}

The Barberries are a most interesting family of shrubs, varying from 2 to 6 feet in height, rich in variety of leaf, flower and habit. The show orange and yellow flowers are succeeded in May or June by bright and various colored fruit. Very ornamental in autumn and winter. Price, $35 \mathrm{c}$ each.

American Barberry. (B.Canadensis.) A native species forming a shrub or low tree with handsome distinct foliage, and yellow flowers from April to June, succeeded by red berries. Price, 35c each.

Berberis Thunbergii. (Thunberg's Barberry). From Japan. A pretty species, of dwarf habit, small foliage, changing to a beautiful red in autumn. The handsomest of the Barberry family. Price, $50 \mathrm{c}$ each.

Purple-Leaved Barberry. (B. C. var. purpurea.) An interesting shrub growing from 3 to 5 feet high, with violet purple foliage and fruit. Blossoms and fruit beautiful; very effective in groups or masses, or planted by itself. Price, 35 ceach.

BUCKTHORN. (Rhamnus catharticus.) The popular hedge plant. Price, $50 \mathrm{c}$ each.

CLETHRA ALNIFOLIA. (Sweet Pepper Bush). This is a new and beautiful shrub. It is perfectly hardy, succeeding in any soil; blossoms pure white and very fragrant; blooms in the autumn. Price, 18-inch plants, 35c each.

\section{DEUTZIA.}

Double Flowering Deutzia.

(D. Crenata var. flore pleno.) Price, 35c each.

Slender Branched De 4 tzia. (D. gracilis.) 18 to 24 inches. Price, $35 \mathrm{c}$ each.

\section{DOGWOOD-(Cornus.)}

Valuable shrubs when planted singly or in groups or masses. Sonle distinguished by their elegantly variegated foliage, others by their bright colored bark. each.

Red Branched Dogwood. (C. Sanguinea.) Price, 50c

Red Siberian Dogwood. (C. Sibirica follis albo-marginata.) Price, 50c each.

Variegated Dogwood. (C. s. var, elegantissima variegata.) Price, $75 \mathrm{c}$ each.

\section{ELDER.-( Sambucus.}

These are showy, large shrubs, quite ornamental in flower, fruit and foliage. They blossom in June.

Black-Berried Elder. (S. Nigra.) Price, 50c each.

Cut-Leaved Elder. (S. n. var. laciniata.) Handsome and popular. Price, $75 \mathrm{c}$ each. each.

Fern-Leaved Elder. (S. n. var.heterophylla.) Price, 75c

Golden Elder. (S. n. var. aurea.) Price, 50c each.

Red-Berried Elder. Price, 50c each.

S. pubens. Price, 50c each.

\section{FLOWERING CURRANT.-(Ribes.)}

Crimson Flowering Currant. (R. sanguineum.) $2 \mathrm{ft}$. Price, 50c each.

Gordon's Flowering Currant. (R. Gordonianum) $2 \mathrm{ft}$. Price, 50c each.

Yellow Flowering Currant. $(R$. Alpina.) $2 \mathrm{ft}$. Price, $50 \mathrm{c}$ each.

\section{GOLDEN BELL.-(Forsythia.)}

Fortune's Forsythia. (F. Fortunei.) $2 \mathrm{ft}$. $50 \mathrm{ceach}$. F. Viridissima. $2 \mathrm{ft}$. Price $50 \mathrm{c}$ each.

$$
\text { HYDRANGEA, }
$$

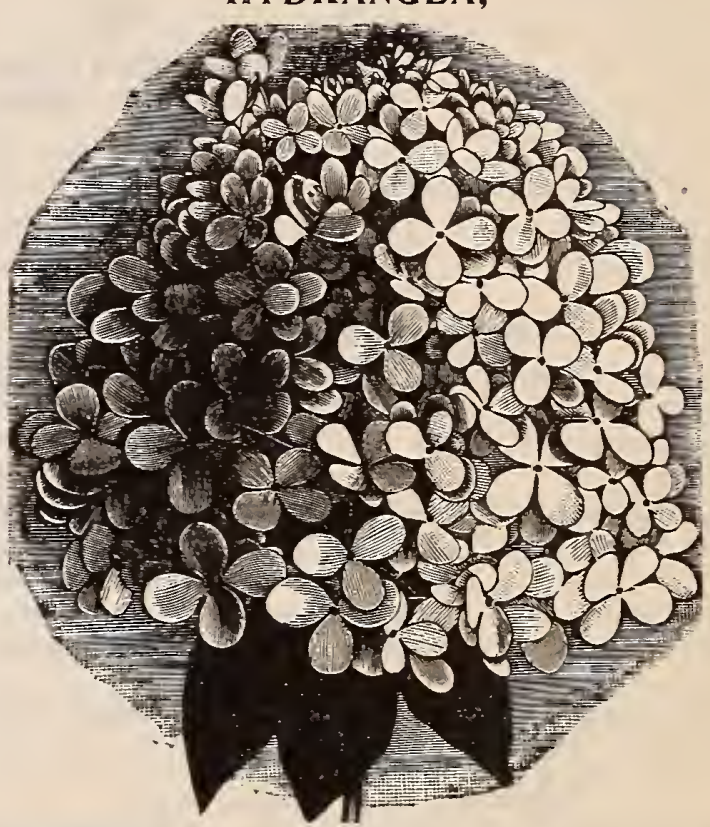

Large Panicle Flowered Hydrangea. (H. paniculata grandiflora.) A fine shrub growing trom 8 to 10 feet high; flowers white, in great pyramidal panicles a foot long and produced in August and September, when very tew shrubs are in flower. One of the finest flowering shrubs. This is the Hydransea Deutziafolia of some nurseries. Price, $50 \mathrm{c}$ each.

\section{LILAC. - (Syringa.)}

Common Lilac. (S. Vulgaris.) Price, 50c each.

Common White Lilac. (S. v. var. alba.) Price, $50 \mathrm{c} \mathrm{each.}$

Jósika's or Chionanthus Leaved Lilac. (S. Josikaea) Price, $75 \mathrm{c}$ each.

Persian Lilac. (S. Persica.) Price, 50c each.

Lemoine's Double Flowered Lilac. ( $S$. F. rar. Lemoinei flore pleno.) Price, $\$ 1.00$ each.

Siberian White Lilac. (S. Sibirica alba.) 50c each.

Verschaffelt's Lilac. (S. Verschaffeltii.) Price, 50ceach.

White Persian Lilac. (S, $P$. var. alba.) Price, $50 \mathrm{c}$ each.

S. v. var. President Grevy. Price, $\$ 1.50$ each.

S. villosa. Price, $\$ 1.50$ each.

S. Lemki. Price, $75 \mathrm{c}$ each.

\section{PLUM, Flowering.-(Prunus.)}

Double Flowering Plum. ( $P$. triloba.) A native of China. A highly interesting and desirable addition to our hardy shrubs. Flowers double, of a delicate pink, upwards of an inch in diameter, thickly set on long, slender branches. Flowers in May. Price, $50 \mathrm{c}$ each.

Dwarf Double Red Flowering Almond. ( $P$.Japonica flore rubra pleno.) Price, $50 \mathrm{c}$ each. 


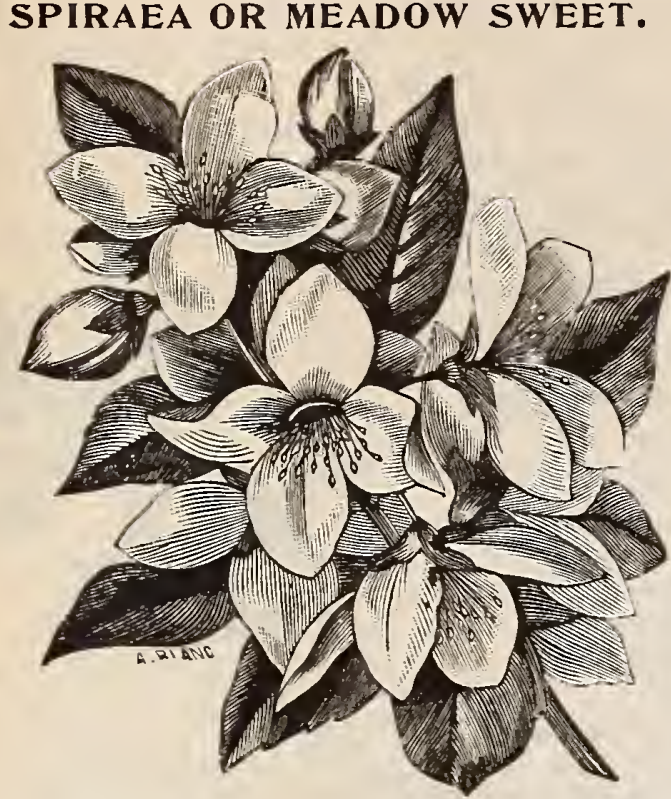

S. van Houttei. Without doubt the finest in the collection. At the flowering season, in early June, the plant is covered with a mass of white flowers, presenting a beautiful appearance. Very hardy. Price, 50c each.

Bumalda. (S. Species Japonica.) Price, 50c each.

Billard's Spiraea. (S. Billardii.) Price, 50c each

Douglas Spiraea. (S. Douglasii.) Price 50c each.

Fortune's Spiraea. (S. callosa.) Price 50c each.

Fortune's Dwarf White Spiraea. (S. c. rar. alba.) Price, 50c each.

Golden-Leaved Nine Bark. (S. opulifolia aurea.) Price, 50c each.

Sorb-Leaved Spiraea. (S. sorbifolia.) Price, 50c each. S. Rotundifolia Alba. Price, 50 c each.

Willow-Leaved Spiraea. (S. salicifolia.) Price, 50c each. ST RAWBERRY TREE.-(Euonymus.)

European Euonymus. (E. Europæeus.) Price,50ceach. White Fruited Euonymus. (E. E. var. fructu alba.) Price, 50c each.

\section{SYRINGA OR MOCK ORANGE.-(Philadelphus.)}

Gordon's Syringa. $(P$. Gordonianus.) A vigorous grower and profuse bloomer. Flowers slightly fragrant and blooms late, and valuable on that account. Price, 50 c each.

P. Aurea. Price, $50 \mathrm{c}$ each.

$P$. Grandiflorus. A large flowered Syringa. 50c each.

P. g. var. speciosissimus. Price, 50c each.

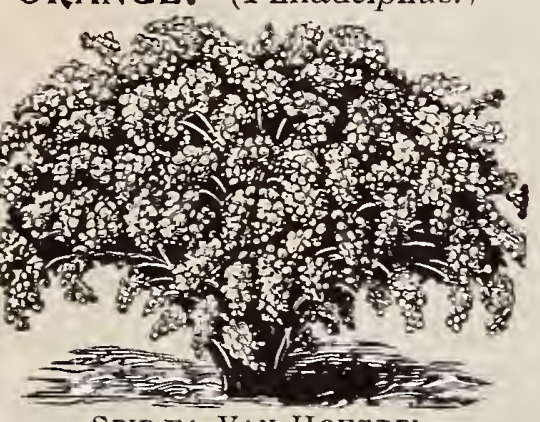

SPIRAA VAN HOUTTEI.

Garland Syringa. (P. Coronarius.) Price, $50 \mathrm{c}$ each.
SUMACH.-(Rhus.)

Cut-Leaved Sumach. ( $R$.glabra var.laciniata.) Leaves fern-like, turning to a rich red in autumn. Price, $75 \mathrm{c}$ each.

Purple Fringe or Smoke Tree. (R.cotinus.) Curious fringe or hair-like flowers. Price, 75c each.

TAMARISK. (Tamarix Arricana.) Handsome foliage; upright habit. Flowers in May. Price, 50c each.

UPRIGHT HONEYSUCKLE.-(Lonicera.)

The following species and varieties are of erect, shrubby habit. The climbing sorts will be found under the head of Climbing Shrubs.

Tartarian Honeysuckle. (L.Tartarica.) Price, 50c each.

L. Alberti. Price, 50c each.

Pink Flowering Honeysuckle. (L. T. rar.Grandiflora.) Price, 50c each.

White Tartarian Honeysuckle. (L. T. var. alba.) Price, 50c each.

White Flowering Honeysuckle. L. T. var. grandiflora alba.) Price, 50c each.

\section{VIBURNUM.-Arrow Root.}

High Bush Cranberry. ( $V$. Opulis.) Both ornamental and useful. Its red berries resembling cranberries, and esteemed by many, hang until destroyed by frost late in the fall; resembles the Snowball in wood and foliage. Price, $50 \mathrm{c}$ each. each.

Pear-Leaved Viburnum. ( $V$. pyrifolium.) Price, $50 \mathrm{c}$

Rough-Leaved Viburnum. (T. lantana var. tugosum.) Price, 50c each.

Sheepberry. (T. lentago.) Price, 50c each.

Snowball Tree, or Guelder Rose. ( $V$. o. var. sterilis.) A well-known and favorite shrub. Price, 50c each. WEIGELIA.-(Diervilla.)

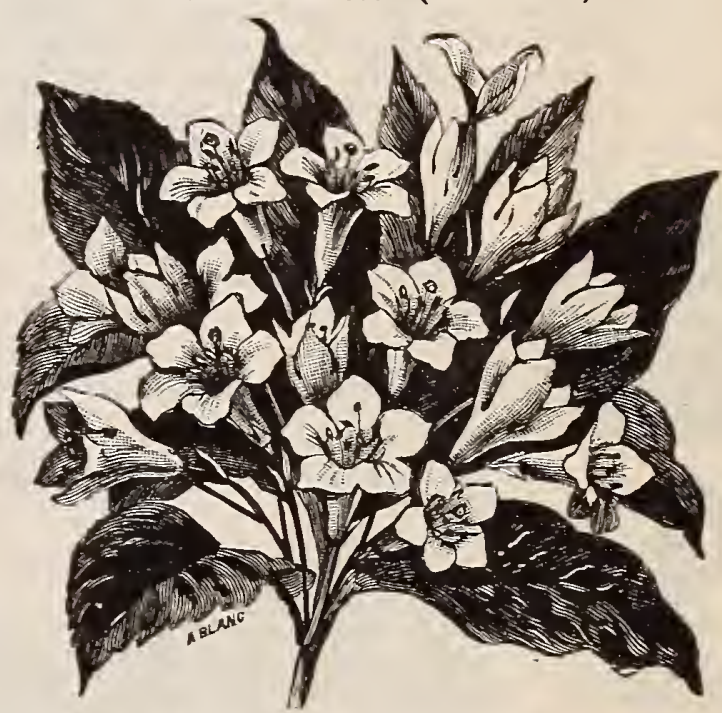

D. Arborea Grandiflora. Price, $50 \mathrm{c}$ each.

D. Rosea. Rose-colored from China. Hardy, most profuse bearer of light, rosy, trumpet flowers in May. In every way the most superb shrub of its season. Price, 50c each.

\section{CLIMBING AND TRAILING SHRUBS.}

American Ivy or Virginia Creeper. (A. Quinquifolia.) Perfectly hardy; foliage rich green, coloring gorgeously in the fall. Fine for covering verandas. Price, $35 \mathrm{c}$ each.

Boston Ivy or Japan Creeper. (A. Veitchii.) Foliage dense; unexcelled for covering tree stumps, etc. Price, 50 c each.

CHINESE MATRIMONY VINE. (Lycium Chinense.) The old-fashioned matrimony vine was a general favorite more than 50 years ago, but in beauty of flower, fruit and foliage, it cannot compare with this superb varietv. It is a most vigorous, hardy, climbing plant when trained to an arbor, fastened to a fence, attached to a tree, to the side of a house, the pillars of a piazza, or in anv location where a hardy, vigorous climber is desired. It sends out numerous branches, so that it covers a great amount of space in a short time, and every new growth is at once covered with flowers, which are succeeded by berries nearly an inch long, every branch being loaded with them; the contrast between the glossy, dark green foliage, and the shining scarlet fruit is extremely beautiful, surpassing Holly in appearance. It continues flowering and new berries are forming from late spring until frost. The berries ripen in early autum and remain on the vine into the early winter. The number of our hardy vines which can be grown without danger from frosts, in our Northern states, is limited, and none are more beautiful than this or as easy of culture. It will grow and thrive in any situation, either shade or bright sun light, and will take root in any soil; in fact nature has given it all the essentials for wide popularity. Valuable as it is for covering fences, etc., it is even more desirable for clambering over stone walls, bare rocks or unsightly banks, covering them quickly with bright green foliage, and later on rendering them objects of beauty with its wealth of scarlet berries and purple flowers. 


\section{CLEMATIS.}

C. Henryi. Very large, fine form; free grower and bloomer; creamy white. Price, $\$ 1.50$ each.

Varieties flowering during the summer in continuous masses on summer shoots.

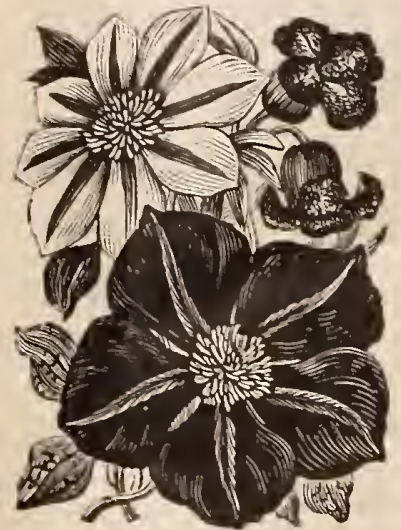

American White Clematis. (C. Virginiana.) A remarkably rapid climbing plant, growing to the height of 20 feet. Price, 35c each.

C. Coccinea. Brilliant scarlet, unike any other variety. Price, $35 \mathrm{c}$ each.

European Sweet Clematis. (C. flammula.) Flowers small, white and very fragrant. Price, $50 \mathrm{c}$ each.

C. Jackmanni. Large, intense violet purple; remarkable for its velvety richness and wonderful freedom in bloom. Price, $\$ 1.50$ each.

C. Viticella. Ouick climber, fine foliage; wine-colored flowers. Price, $35 \mathrm{c}$ each.

CLIMBING CELASTRUS, or Bitter Sweet. (Celas trus scandens.) Leaves large; rellow flowers; Ornamental all winter. Price, $35 \mathrm{c}$ each.

\section{Hardy Herbaceous Flowering Plants.}

This class of plants is rapidly coming into favor, and the demand for them is increasing every year. The ease with which they may be grown and the great variety of flowers and foliage, ranging over the whole growing season, make them rery attractive and very desirable. Once planted they care for themselves, if insured freedom from grass and weeds. Some of the nore tender varieties may bloom better for a winter protection of litter or coarse straw.

By selecting carefully, with reference to time of blooming, a succession of flowers may be obtained during spring, summer and autumn. The majority present an attractive appearance even when not in bloom. We would call special attention to the different rarieties of Aquilegia, Delphinium, Spirea, Prrethrum, Plantain Lilies, Dicentra, Phlox, Golden Rod, etc.

Our list is one that we can fully recommend. We are testing many other varieties, and will offer them from time to time, as they prove wortlyy. If any plant is desired that is not listed here, write us, and we will try to furnish it.

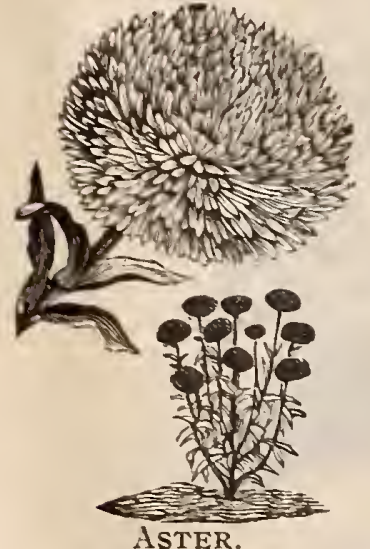

BLEEDING HEART.-(Dicentra or Dielytra.)

D. Spectabilis. Price, 25 c each.

\section{BUTTERCUP.-(Ranunculus.)}

R. aconitifolius Iuteo pleno. Double orange rellow Crowfoot. Price, 25c each.

\section{CALIFORNIA COLUMBINE.-(Aquilegia.)}

In variety of colors, ranging blue, red, rellow, etc.

A. alpina. Long stems, showy blue flowers. Price, 50c each.

A. Canadensis. Scarlet sepals and rellow petals. Easilv cultivated. Price, $50 \mathrm{c}$ each.

A. Olvmpica. Flowers red and vellow. Price, 50c each.

A. Formosa Hy-brida. Syn. Californica $\mathrm{Hy}_{\mathrm{y}}$ brida. Orange red spurs. Price, $60 \mathrm{c}$ each.

CHALK PLANT.-(Grpsophila Paniculata.) A fine herbaceous plant, forming a compact bush; flowers small, white, in large loose panicles. Valuable for bouquets. Price, $25 \mathrm{c} \mathrm{each}$.

CLEMATIS CAERULIA. Large auxiliary clusters o fragrant blue flowers. Price, 50c each.
CRANES BILL. (Geranium.) Not Pelargonium or Scarlet Geranium. Price, 25c each.

DAY LILY. (Hermerocallis.) Plants of great merit, thriving in an ordinary soil. All have grass-like foliage, with showy lily-like flowers. They are excellent for border plants, for grouping and in the rockery. Yellow, hardy and rerp fragrant. Price, 50c each.

H. Dumortierii. A splendid Japanese variety, with deep orange-yellow flowers; brown outside. Price, $50 \mathrm{c}$ each.

H. Flara. Onginally from Siberia and is perfectly hardy; height about 2 feet; with clusters of bright rellow flowers of pleasing fragrance. Price, $35 \mathrm{c}$ each.

H. Variegata. A showy double, copper tinged, orange flower. Blooms verr profusely for several weeks in July and August. This is one of the most desirable of the day lilies. Price, $50 \mathrm{c}$ each.

$H$. Var. V. A handsomely rariegated silvery foliage, shaded with green. A plant that attracts attention erervwhere. Price, 50c each.

EULALIA. Hardr ornamental grasses used for decoration of lawns and borders, and in rases. Their graceful habit and stately appearance render them a most striking ornament and rery pleasing to the eve. Ther grow to a height of from 4 to 6 feet, and plumes cut in the fall will retain their beauty all winter. We grow the following choice varieties that are perfectly hardy in this climate and need no protection whatever.

E. Japonica Zebrina. The most distinct and show of all the Eulalias; the variegations of the foliage is entirely differeut from that of an $>$ other plant, being erenly striped cross-mise, with broad bands of golden rellow. Perfectly hardy, a sturdy grower, increasing in size and beauty from rear to year: a plant that has been established two or three years often producing from 50 to 100 of its beautiful large plumes. Price, strong plants $35 \mathrm{c}$ each.

E. Japonica Variegata. A farorite ornamental plant, haring long, narrow leares, striped white and green. Price, strong plants $35 \mathrm{c}$ each. 


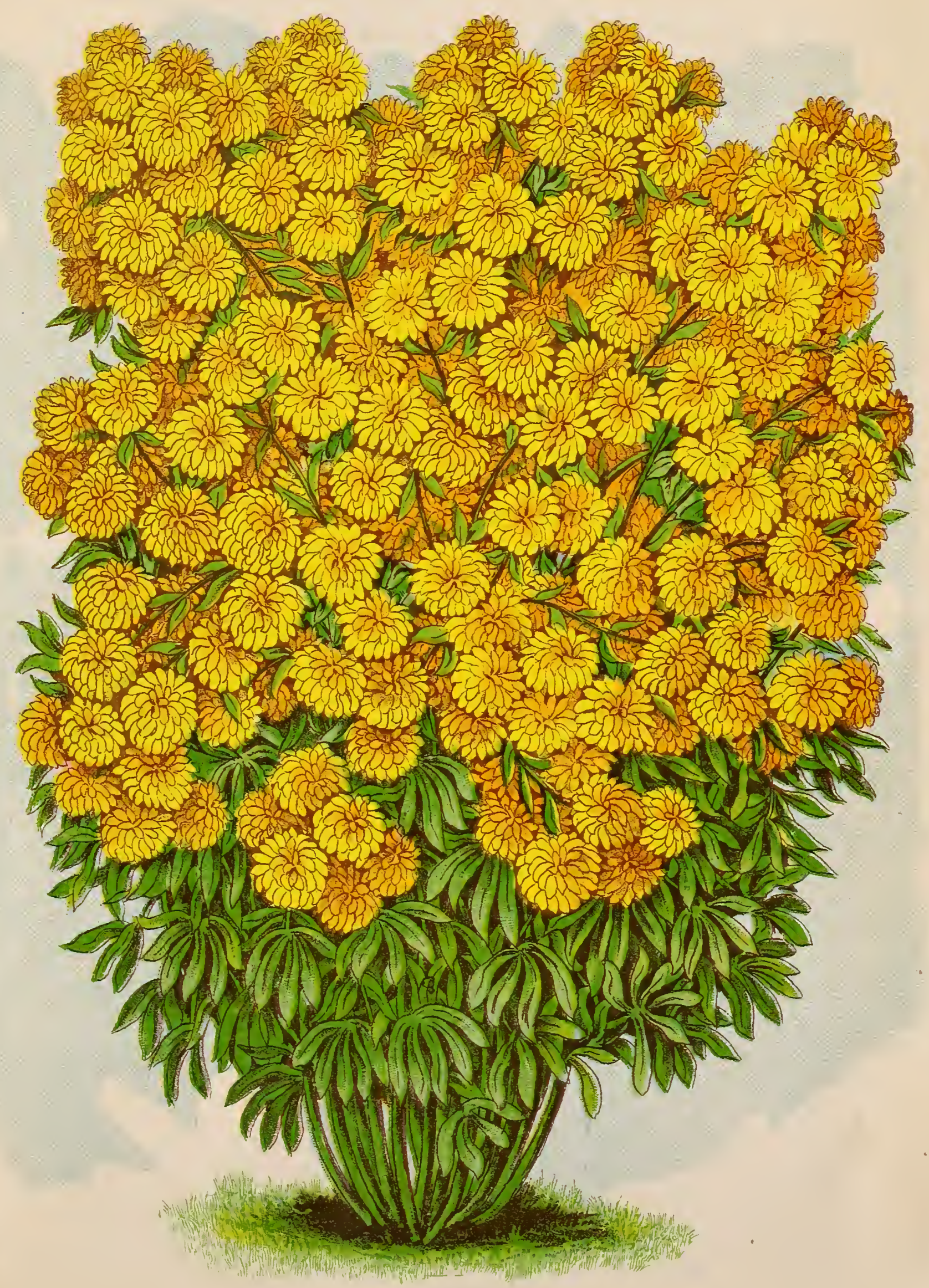

GOLDEN GLOW, OR SUMMER CHRYSANTHEMUM. 


\section{Golden Glow, or Summer Chrysanthemum.}

It is with great pleasure we call the attention of Lovers of FLowers to this Sterling Novelty, and we assure them that it is a plant of no common merit. This GLORIOUS HARDY Flowering plant was introduced in the spring of I896, and first brought to notice by Mr. Wm. Falconer, then editor of Gardening, now Superintendent of Schenley Park, Pittsburgh, Pa., and when seen in flower, jumped at once into popularity and favor, as being, perhaps, the Best HARdy Plant in cultivation.

\section{IT IS PERFECTLY HARDY,}

Withstanding the coldest winters without any protection. It is a rapid grower, attaining in good soil a height of 6 to 8 feet the same season planted, and commences to bloom in July, lasting into September, a period of eight weeks. Its flowers are double, attaining a size of $3 \mathrm{I} / 2$ inches in diameter, borne on long stems, making it very suitable for cutting, and are of a deep GOLDEN YELLOW, and last a long time when cut. In appearance they are like fine yellow chrysanthemums, and quite as attractive and desirable. In planting place the roots straight down, and make firm and solid, then cover the crown of the plant with two inches deep of soil. A mulch, also, of manure will be of great benefit, and the plants will attain greater success the next season.

\section{LOVES A DEEP, RICH SOIL.}

It being a strong growing plant, it needs a DEEP, RICH SoIL to succeed perfectly. The second year after planting, the plants attain a large size, making, when in flower, a huge bush of golden yellow, which can be seen a great distance, giving an added charm to any place. It is very suitable in the background for small places, or for the shrubbery, when desirable. We Confidently Recommend it as the Best New Plant in Cultivation.

Water liberally when necessary during dry weather. After blooming, cut off the flower stems close to the ground, to preserve a neat and tidy appearance. Price 50c. each; $\$ 400$ per doz.

\section{PYRETHRUM ULIGINOSUM.-Great Ox-Eye, or Giant Daisy.}

A perfectly hardy perennial growlng 4 to 6 feet high ; of upright growth, with bright green foliage, and bears a profusion of pure white flowers with yellow centers. Individual blossoms are from 2 to 3 inches across. It is hardy everywhere, requiring but little care and no protection. It is grown largely in groups and borders. It begins to blossom in midsummer and the flowers last until after severe autumn frosts. The blossoms are also esteemed for decoration purposes, as they keep well for many days after being cut. Price, strong plants, $25 \mathrm{c}$. each ; $\$ 2.50$ per doz.

\section{GAILLARDIA GRANDIFLORA.}

A beautiful perennial plant, with drooping leaves, producing blossoms on long stems, 2 to 3 inches in diameter, in shape like a field daisy. The flowers have a dark red-brown center, with petals of orange-crimson and red shading into rings of most gorgeous colors. The plants die to the ground in the winter, but come forth in early spring with renewed vigor. Needs no care, and flourishes on a rather poor, thin soil, blooming in the most wonderful profusion from May to November. Price 25c.

\section{A BEAUTIFUL COMBINATION.}

One of the most striking combinations for lawn decoration can be made by planting the Golden Glow for a center and then surrounding it with a row of the Pyrethrum Uliginosum, and that, in turn bordered with a row of Gaillardia Grandiflora. These all blossom at the same time. The Golden Glow grows 5 to 6 feet high, the Pyrethrum 4 to 5 feet, and the Gaillardia 2 to 3 feet, thus exposing the whole flowering surface of the magnificent plants to view at once. The season and habits of all these are similar, they bloom at the same time, they all carry their flowers till after severe frosts, and none of them require any particular care. Estimates and designs for groups furnished FREE. Write us. 
FEVERFEW. (Pyrethrum.)

$P$. Roseum. Extremely showy and valuable for cut flowers. Price, 25c each.

P. uliginosum. Fall blooming; pure white. Price, $25 \mathrm{c}$ each. GAILLARDIA GRANDIFLORA.

A beautiful perennial plant with drooping leaves, producing blossums on long stems, two to three inches in diameter, in shape like a field daisy. The flowers have a dark red-brown center with petals of orange crimson and red, shading into rings of most gorgeous colors. The plants die to the ground in winter, but come forth in early spring with renewed vigor. Needs no care, and flourishes on a rather poor, thin soil, blooming in the most wonderful profusion from May to November. Price, 25c each.

GOLDEN GLOW. (Rudbeckia.)

A hardy perennial, growing six to seven feet high, and producing hundreds of bright, golden flowers, two or three inches in diameter, on long graceful stems, forming immense heads of bloom. They bloom late in the season when most needed, and are of the easiest culture, requiring only an ample supply of moisture for the best results, and are perfectly hardy. When once established, they readily spread, forming immense clumps from four to six feet in diameter. It thrives readily in ordinary soil, but where plants are not given sufficient moisture, the blossoms are much smaller. A very little care will insure the niost satisfactory results, for when once well established, it will furnish an endless amount of flowers. Price, 10 c each; 3 for 25 c.

GOLDEN ROD. (Solidago.)

S. cæsia. August. Purple stems, slender drooping habit: flowers bright yellow. Price, 25c each.

Drummond's Golden Rod. (S. Drummondii.) Graceful, leafy stems, with bright yellow flowers in upper axils. Price, 25 ceach.

IRIS.' (Fleur de Lis.)

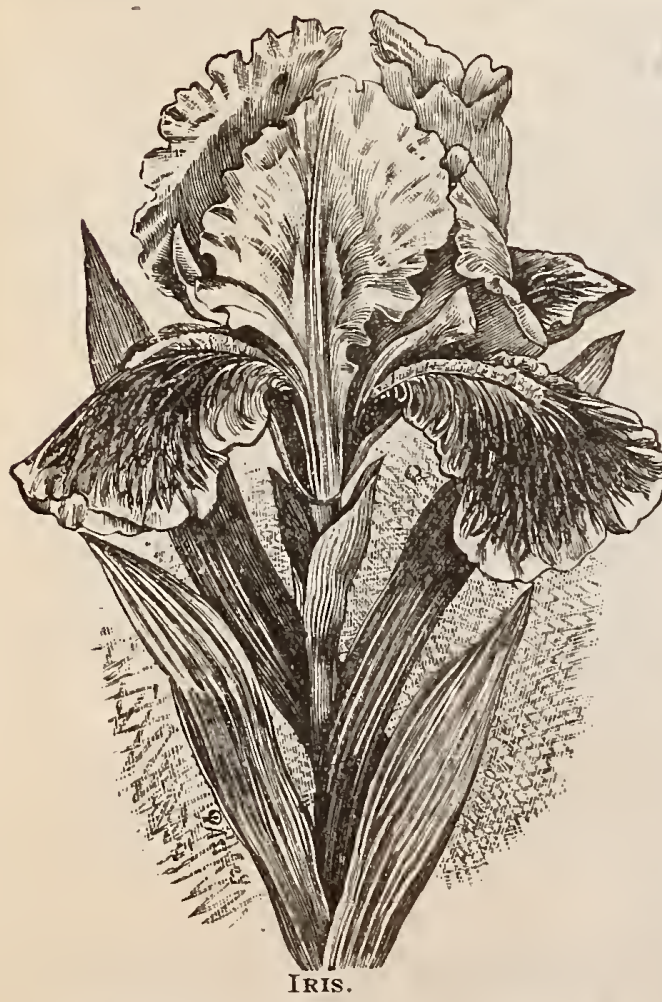

I. Apollon. Golden yellow, striped with plum color. Price, 25c each.

I. aurea. Clear, golden yellow. Fine. Price, $25 \mathrm{c}$ each.

I. falcata Yellow, tinged with purple and purple stripes. 2 feet. June. Price, 25c each.

I. Hava. Pale vellow. Fine. 2 feet June. Price, $25 \mathrm{c}$ each.

I. florentina. White, tinged with blue and yellow. 2 feet. May. Price, 25c each. Japan Iris.

I. Kimpferi. Flowers different from the ordinary kinds, in being broad and flat. Price, 50c each.

I. Sampson. Rich golden yellow, crimson maroon, veined with white. Fine. Price, 25c each.

JAPAN SPIRAEA. (Astilbe Japonica.) Small, pure white flowers, in large, branching panicles. Price, $30 \mathrm{c} \mathrm{each}$.

LARKSPUR. (Delphinitum.) Pyramidal or tall growers. Price, 25c each.

LAMP FLOWER. (Lychnis chalcedonica.) Scarlet Livchnis. Brilliant scarlet; large truss. 3 feet. July and August. Price, 25c each.

\section{LYSIMACHIA.-(Loose Strife.)}

Moneywort. (L. nummularia.) Creeping habit, fine for hanging baskets and covering rock work. Price, $25 \mathrm{c}$ each.

\section{MOCCASIN FLOWER, or Ladies' Slipper.}

\section{(Cypripedium.)}

C. Pubescens. Yellow Moccasin Flower. Flowers on leafy stems, bright yellow, with long curled sepals. Price, $35 \mathrm{c}$ each.

C. Spectabile. Pure white, inflated tips, blushed crimson. Price, 25c each.

ORIENTAL POPPY. (Papaver orientale.) Deep scarlet: large, very showy. 18 inches. June. Price, $30 \mathrm{c}$ each.

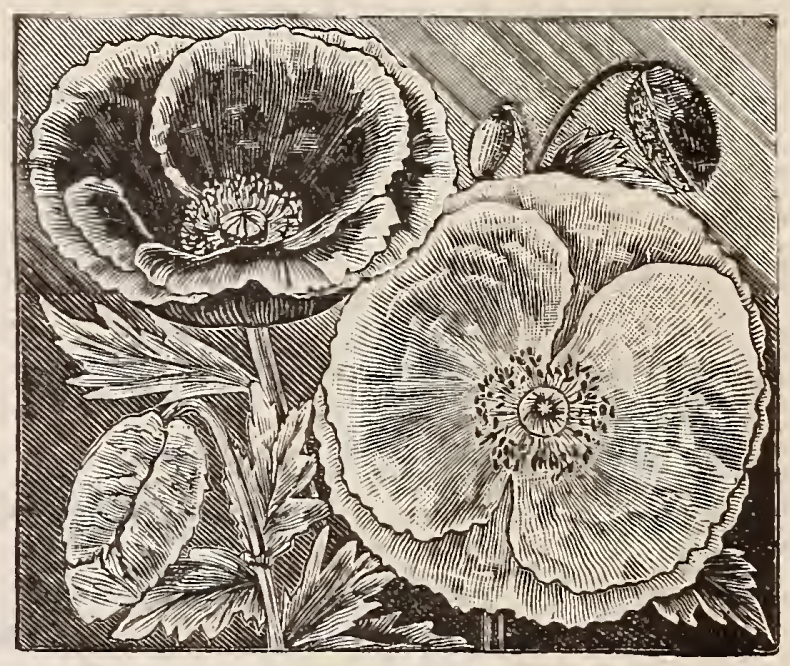

PERENNIAL PEA.-(Lathyrus.)

L. Latifolius albiflorus. Pure white flowers in clusters. Valuable for cut flowers all summer. Price, $50 \mathrm{c}$ each.

PHLOX.

These are justly esteemed the finest of herbacepus plants. They are of the dwarf habit, perfectly hardy, of very easy culture, and yield a profusion of bright, showy bloom. They are hardly equaled by any other hardy plant for the decoration of the garden.

P. amœna. Lovely Phlox. Flowers pinkish purple, completely covering the plant in spring. One of the best early flowering species. $25 \mathrm{c}$ each.

$P$. procumbens. Lilac with violet marks near the eye, dwarf, May. 25c each.

P. subulata. Moss pink. Moss-like leaves; flowers pinkish-purple with a darker center. Price, $25 \mathrm{c}$ each.

P.s. var. alba. A white flowering variety of the above. Price, 25c each.

$P$. Francois Coppee. Large, creamy white flower, carmine rose ccnter. Price, $50 \mathrm{c}$ each.

P. Gambetta. Rose; vivid red eye; a splendid sort; tall. Price, 50c each.

P. Lothair. Rich salmon color; crimson eye; large flower and spreading spike. Price, 50c each.

$P$. Madame Lechurval. Silvery rose; crimson eye; very fine. Price, 35c each.

$P$. Phoceon. Lilac rose, with carmine eye; large panicles. Price, $50 \mathrm{c}$ each.

P. Premier Ministre. Rosy white, center deep rose; very fine. Price, $50 \mathrm{c}$ each.

$P$. Queen. Pure white; fine; medium height. $25 \mathrm{c}$ each.

P.Richard Wallace. White, with violet center; very large flower; tall. $35 \mathrm{c}$ each.

$P$. Vierge Marie. Pure white of a beautiful waxy texture, tall. Price, 25ceach.

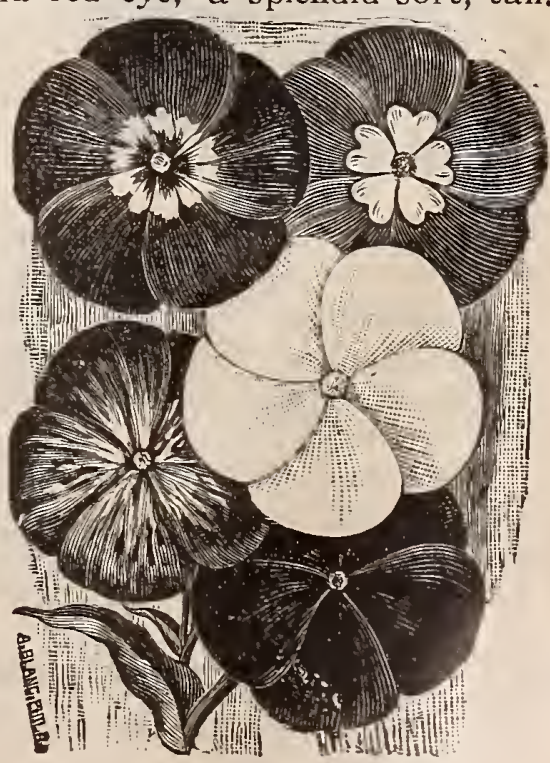

Priox. 


\section{PINKS.}

Hardy Garden, or May Pinks. Valuable dwarf; hardy plants, that will grow anywhere and increase in beauty every year. They have a delightful and clove-like fragrance that adds much to their value for cut-flowers. When fully developed the plants are a perfect mass of bloom for a long period. 10c each, 12 for $\$ 1.0($, except where noted.

Abbotsford. Deep carmine, marbled with white; rich clove fragrance.

Essex Witch. Delicate pink; finely fringed.

Gertrude. White with maroon markings.

Her Majesty. Flowers clear white, very double, exhaling an exquisite clove-scented fragrance; very free bloomer. $15 \mathrm{c}$.

Lord Lyons. Dark maroon with lighter shadings.

Mary Gray. Reddish purple, narrow lacing of white.

Souvenir de Sale. An entirely new shade in hardy Pinks. A delicate soft rosy pink, very double and very useful for cutting.

Variabilis. White, deep maroon center.

\section{PLANTAIN LILY.-(Funkia.)}

F. Cærulia. Light blue with dark green, glossy foliage. Price, 25c each.

F. Grandiflora. Large blue flowers. Price, 25c each.

PRIM-ROSE, or Cowslip. (Primula veris.) Flowers bright yellow in terminal umbels; spring and early summer. Price, 25c each.

RIBBON GRASS. (Arundinaria foliis variegata.) Valuable for edgings. Leaves striped longitudinally with green and cream color; very handsome; free growing. $15 \mathrm{c} \mathrm{each.}$

\section{SPIRAEA-Meadow Sweet.}

Dropwort. (S. filipendula.) Large, showy heads of white flowers, tinged rose. $25 \mathrm{c}$ each.

Dropwort. (S. F. var. $f$. pl.) Double white flowers; fernlike foliage. Price, $25 \mathrm{c}$ each.

Goat's Beard. (S. Aruncus.) Large panicles of creamy white flowers. Price, 25c each.

S. Ulmaria fl. pl. Double white Meadow Sweet. A very desirable hardy plant. $25 \mathrm{c}$ each.

$S$. $U$. var. fol. var. Golden variegated foliage. $25 \mathrm{c}$ each.
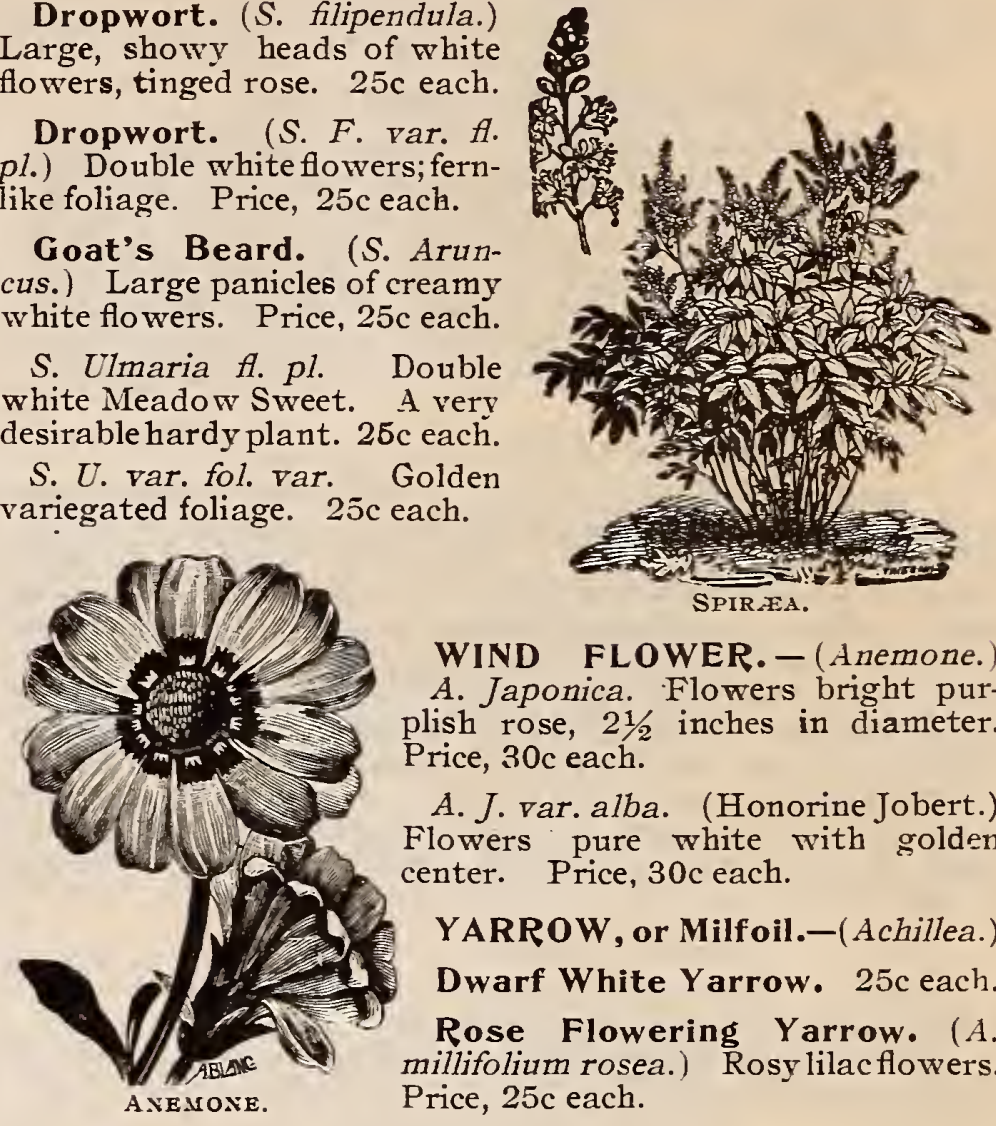

WIND FLOWER. - (Anemone.) A. Japonica. Flowers bright purplish rose, $2 \frac{1}{2}$ inches in diameter. Price, 30c each.

A. J. var. alba. (Honorine Jobert.) Flowers pure white with golden center. Price, $30 \mathrm{c}$ each.

YARROW, or Milfoil.-(Achillea.)

Dwarf White Yarrow. 25c each.

Rose Flowering Yarrow. ( $A$. millifolium rosea.) Rosylilacflowers. Price, 25c each.

\section{PAEONIAS.}

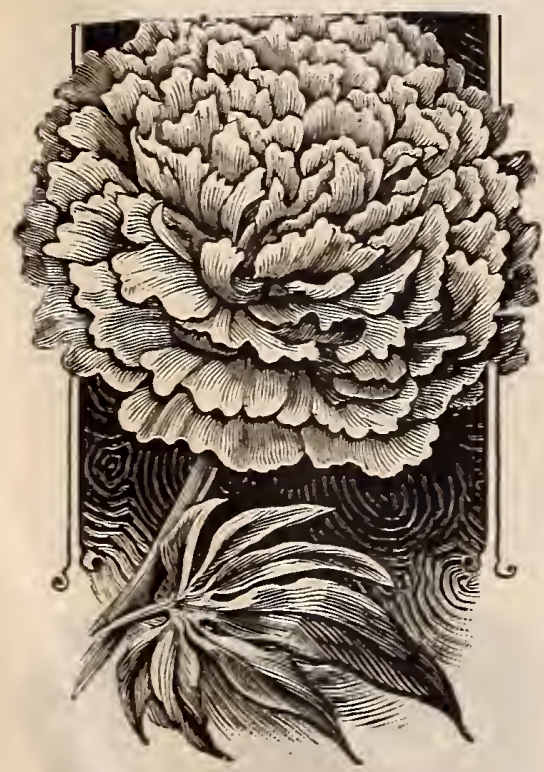

ClASS I.-TREE PAEONIAS. (Pæony Moutan.)

Arethusa. Light rose, shaded with purple; large and fragrant. Price, $\$ 1.00$ each.

Tree Paeonia. (Banksii.) A handsome flowering shrub, growing from 3 to 5 feet high with good care. The blossoms are remarkably striking, of gorgeous color and enormous size; from 5 to 7 inches across. In color a rosy blush, with an agreeable fragrance. Among the earliest plants to bloom. Price, $\$ 1.00$ each.

Extensa. Very large; rose; clouded with purple. Price, $\$ 1.00$ each.

\section{CLASS II-HERBACEOUS PAEONIAS.}

A very showy and most useful class of plants, almost rivalling the Rose in perfume, brilliancy of color and perfection of bloom. They are exceedingly hardy and flourish anywhere, no matter how cold. They require little or no care and grow and blossom well in almost any soil. but the flowers will be finer, larger and much brighter in color, if planted in deep, rich loam, and well manured. If you don't have clay soil spade in a liberal amount of well rotted manure, and if your soil is light and thin, then use the manure in the form of a top dressing and you will have a wealth of beautiful, fragrant blossoms of immense size.

Delicatissima. Delicate fine rose; very large. Price, $25 \mathrm{c}$ each.

Festiva. Pure white, with a few marks of carmine in the center. Price, $25 \mathrm{c}$ each.

Festiva Maxima Evertsii. Resembles the Festiva, but Flowers are larger; pure white, center streaked with carmine. One of the finest in our list. Price, $50 \mathrm{c}$ each.

Grandiflora. Very large, delicate blush, center fringed with yellow. Price, 25c each.

Rosea. Light rose color; very double; fine. Price, $25 \mathrm{c}$ each.

Rubra. Bright crimson, with conspicuous yellow center. A very handsome and distinct member of the Pæonia family. Price, 25c each.

Modesta. Deep rose, fine shape; very fragrant. Price, 25 c each.

Whittleji. This is the finest of the herbaceous Pæonias, being a distinct type and rery fragrant. Pure white; very large flowers, center slightly yellowish, and rich dark green foliage. Price, $\$ 1.00$ each.

BuFFALO LAKE, MINN., April 19, 1897.

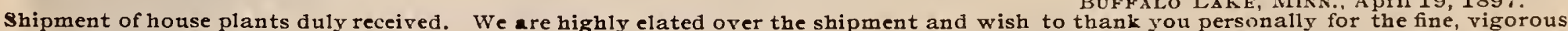
plants. Every one will live.

MCGREGor, Iowa, March, 1897.-The flowers you sent were the best and cheapeet I have ever had from any florist.

MISS FLORENCE MCMICHAEL. 


\section{DAHLIAS.}

Price, 25 cach; $\$ 2.50$ per doz., except where noted.

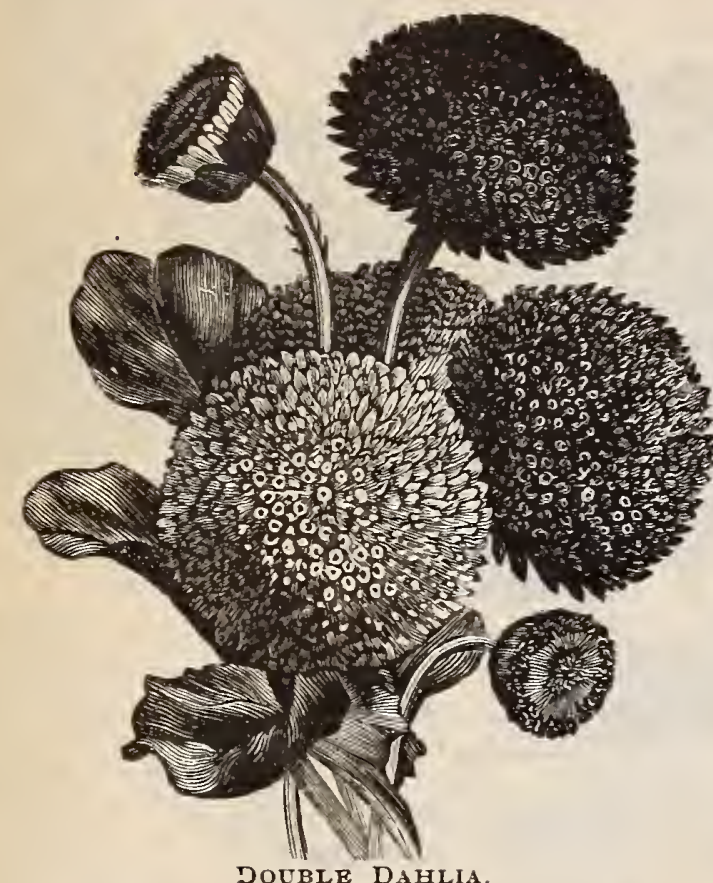

Ami Barillett. A new single Dahlia. Flowers deep scarlet crimson, very rich in color. Its deep purplish maroon graceful foliage renders it very attractive and valuable for bedding in contrast with lighter-leaved plants. It is admirable for a border around a bed of French Cannas.

Amorette. A double variety, with beautiful deep crimson flowers.

Beauty. Large flowers, pure white in color. A very attractive variety

Bredowillard.

low, evenly colored, without markings.

Canary Bird. Flowers of a good size, of a bright, clear canary yellow in color.

Dandy. White with carmine spots. Very striking and attractive in appearance.

La Phare. A brilliant scarlet. A handsome and showy flower.

Mary. A bight scarlet. Very strong grower and excellent for producing sharp contrasts in color beds.

Nymphae. Large flowers, with heavy, broad petals, those of the center being somewhat cupped or incurved. Color is a slear, distinct, light shrinı pink, shading slightly darker toward ilie center.

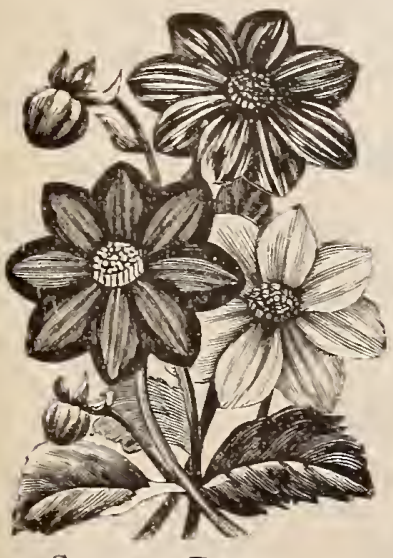

Oriole. Rich golden yellow in color. A good grower and a free bloomer.

Pearl. A beautiful deep mauve in color. Very distinct. Blooms hold till late frosts.

Purpurea. Large brilliant scarlet flower without markings. A beautiful and solidly colored blossom.

Snowdrift. A pure snow white, beautifully clear. A free bloomer and a very desirable variety.

White Queen. A single variety, with a large, clear white blossom. Very desirable and attractive.

All the above are double, except Ami Barillett and White Queen, SINGLE, DAHLIA. which are single-flowered varities.

\section{GLADIOLI.}

Price $15 \mathrm{c}$ each; $\$ 1.50$ per doz., except where noted.

Diamant. An early flowering variety. Color fleshy white, reniarkably fresh and beautiful. Throat ivory white, blotched and streaked with carmine.

General Sherman. Flowers are of large size, and a deep, brilliant scarlet in color. Evenly colored, and very brilliant and showy.

Aurore. A brilliant rosy salmon, striped with orange, carmine and lilac, blotched with cherry rose with violet streaks.

Ben Hur. Large flowers of a very peculiar color, thickly studded on a large compact spike. Color light salmon rose, tinged and mottled with blue. Throat spotted with white and bright carmine. Price 20̃c each.

Ceres. A beautiful pure white, handsomely blotched with dark rose-colored spots.

Columbia. Light orange scarlet, freely blotched with bluish purple. Base of petals rayed with pure white. Throat mottled and spotted with white and violet.

Dr. Sellew (or Seller). Flowers very large and of great substance, borne on a large spike. Deep rich, rosy crinison color, slightly penciled darker. Center of petals rayed with white. Throat pure white, spotted with violet crimson. Price, $25 \mathrm{c}$ each.

Hesperide. Flowers pure white, profusely and beautifully blotched and flaked with bright, rosy salmon.

Isaac Buchanan. An elegant variety. Flowers of a clear, deep solid yellow. Very beautiful and attractive.

John Bull. Flowers almost entirely white, slightly tinged with yellow.

Madame Lemoinei. Spike thickly set with good-sized flowers. Upper petals creamy white; tinged with salnon red. Lower ones spotted purplish crimson, bordered with bright yellow and salnion red.

May. Large spikes closely filled with well-expanded flowers. Color white delicately touched with pink. Two lower petals beautifully penciled with a peculiar light brown.

Seduction. Rosy salmon, very bright and open. Throat very clear, with a large white blotch, feathered with carmine.

Snow White. Large flowers of fine shape. Pure white in color, seldom showing a trace of any other shade. Spikes are large and thickly set with flowers.

William Falconer. Spike of great length. Flowers very large, and delicately shaded with light pink and blush, beautifully mottled and internixed. Throat spotted with crinson and white. Price, $25 \mathrm{c}$ each.

\section{LILIES.}

\section{(Lilium.)}

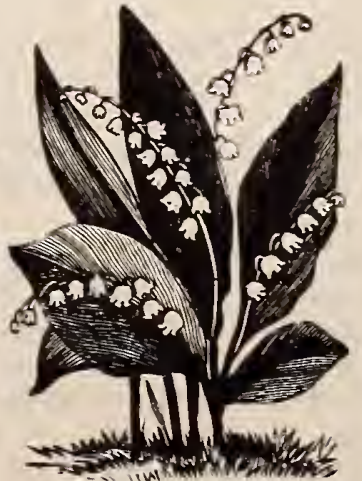

Double Tiger Lily, (L. Tigrinum f. pl.) Bright orange scarlet, with dark spots. A strong-growing, showy variety, and entirely hardy. Succeeds well everywhere. Price, 50c each.

Tiger Lily. (L. Tigrinum.) Bright orange with dark spots. Hardy. Price, $25 \mathrm{c}$ each.

Lily of the Valley. (Convallaria Majalis.) This beautiful little plant is extensively grown for forcing in the winter and early spring months. It is perfectly hardy, preferring a slightly shaded LILY OF THE VALLEY. situation. Price, 1j̃ each.

L. Tenufolium. This beautiful Lily is a native of Siberia and perfectly hardy. It blooms early in the season. The color is a lovely vermillion scarlet; very handsome. Price, j0c each.

ELLSTIORTH, MINN., March 19, 1897.-The goods I ordered of you last fall came in good shape and are highly satisfactory. J.G. MORRISON

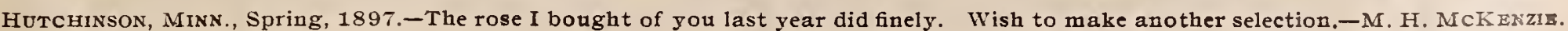




\section{Greenhouse Bulbs, Plants, Roses, Vines, etc.}

Plants from 21/2 inch pots may be sent by mail, larger plants must go by express or freight. Write for special prices for plants in larger sizes and numbers.

\section{ABUTILON.}

FloweriNg Maple.

Prices, Ist size, $25 \mathrm{c}$ each; 2 nd size, $15 \mathrm{c}$ each, except where noted.

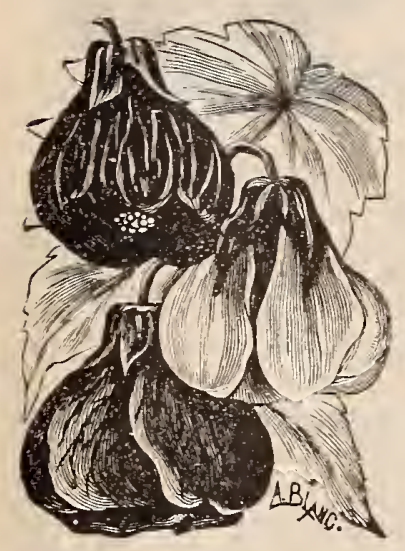

This plant is a strong healthy grower, a free bloomer and has a handsome, variegated leaf. The flowers stand well out beyond the foliage, and their graceful habit and beautiful colors make it one of the handsomest plants either for borders, for vases or for window boxes.

Boule de Niege. Pure white, bell-shaped flower. A splendid pot plant.

Fire Fly. Bright red. One of the handsomest of the Flowering Maples. Price, 1st size, 30c each; 2nd size, $20 \mathrm{c}$ each.

Golden Fleece. Bright golden yellow. A free bloomer, lasting the whole season.

\section{ANTHERICUM VAR.}

Price, Ist size, 25c each; 2 nd size, $15 \mathrm{c}$ each.

An elegant house plant with dark green leaves, beautifully bordered with stripes of pure white. It throws uplargespikes of small, star-shaped flowers, which are very effective. Fine for hanging baskets.

\section{BEGONIAS.}

Prices, Ist size, $25 \mathrm{c}$ each, $\$ 2.50$ per doz.; 2nd size, $15 \mathrm{c}$ each, $\$ 1.50$ per doz., except where noted.

The most useful and ornamental of the house plants. They are beautitul in flower and leaf; free blooming, and easy, sure growers.

Alba Picta. Leaves glossy green, thickly spotted silvery white.

Gilsoni. New double. Flowers large, white, shaded carmine.

Jules Cretain. Foliage fine, beautifully shaded. Large flowers.

Metallica. Shrubby variety. Good grower. Free bloomer.

Olbia. Grand variety. Leaves from 7 to 10 inches in diameter. Flowers white.

Perle de Paris. Solid silver leaf, distinct and fine.

Rubra. Dark green leaves. Flowers a beautiful rosy scarlet.

Sandersoni. A bushy variety, with glossy, dark green foliage. Heart-shaped scarlet flowers, borne in clusters. A free bloomer.

Semperflorens: Medium size. Glossy olive green leaves. Flowers a rosy flesh color. Blooms constantly.

Weltoniensis Alba. Fine house plant. Foliage delicately tinted. White flowers.

Weltoniensis Rubra. Fine house plant. Foliage delicately tinted. Pink flowers.

\section{REX BEGONIAS.}

\section{Prices, lst size, $35 \mathrm{c} ;$ 2nd size, $25 \mathrm{c}$, except.} where noted.

Countess Louise Erdody. Beautiful; lobes of leaves with spiral twist.

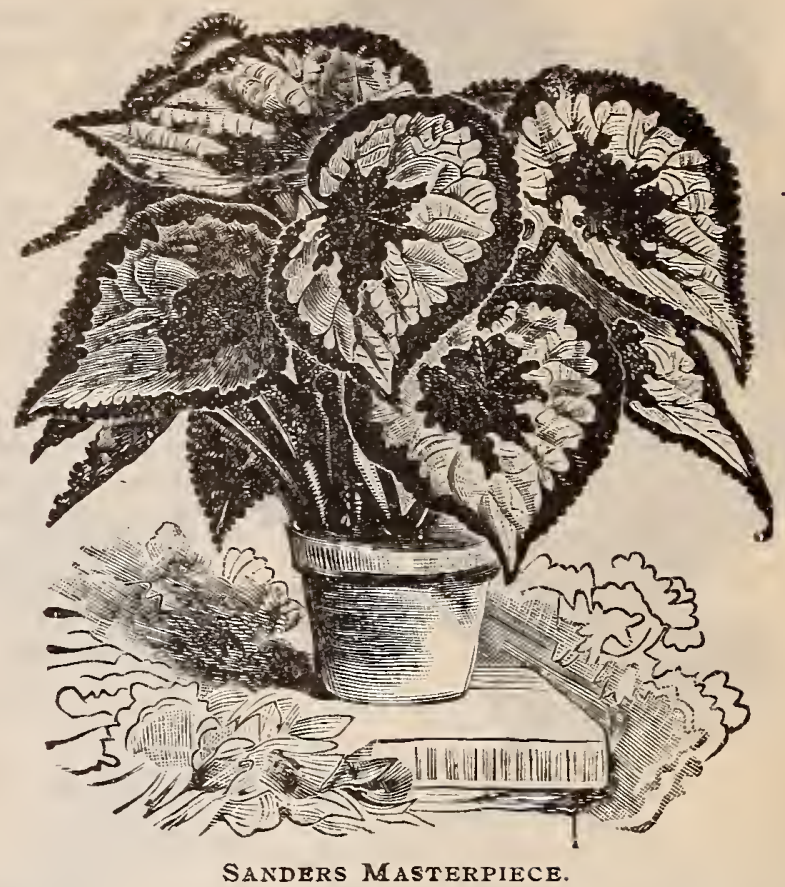

Lesoudii. This variety has the largest leaves of any of the Rex family.

Madame le Boucq. A very distinct variety. Leaf a rosy mauve color, occasional touches of plum color, very high silky luster.

Mrs. Cleveland. Strong grower; foliage deeply indented; leaf deep olive green, heavily blotched with silvery white.

Queen of Hanover. Leaf soft and velvety, covered with a red pile; centcr and edge of soft green, the zone formed by sinall silver dots.

Sanders Masterpiece. Verr highly colored with leaves of a metallic luster, the entire center being pink with a narrow edge of bronze green. The colors are entirely distinct and very beautiful. Price, 1 st size, 50c; 2nd size, 35c.

\section{CARNATIONS.}

"The Divine Flower," are the most esteemed of the florists' collections, and there is no flower more desirable for the garden. Next to the Rose they are the favorite flower with all classes.

\section{Prices, Ist size, 25c; 2nd size 15c, except where noted.}

Daybreak. Flowers very large, perfectly double, clear, bright flesh tint.

Lizzie McGowan. This Carnation is a splendid grower, producing very large pure white flowers that are beautifully tringed; delightfully fragrant.

Portia. A beautiful brilliant scarlet.

President Garfield. A strong growing, buslyy varicty, producing very large flowers of a deep rich crimson. A very iree late blooming variety, and one of the best.

Silver Spray. Flowers pure white, large, perfect and all on long stems.

William Scott. The habit of this plant is branching, vigorous and extremely healthy. In color it is a clear, delicate rosy pink. 


\section{CHRYSANTHEMUMS.}

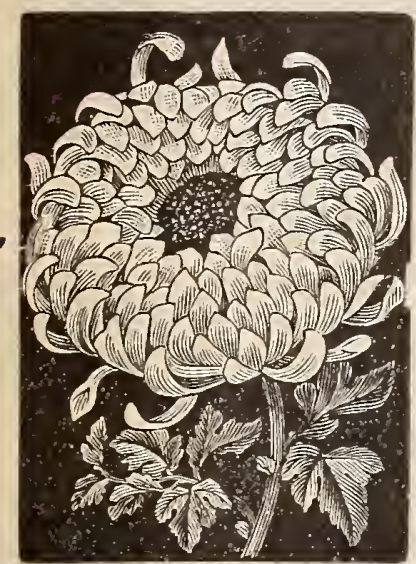

This, the national flower of Japan, has become very popular of late, and the great improvement in varieties, culture and development has been remarkable. It is esteemed very highly for the ease with which it is grown, its freedom from disease, and the elegance and beauty of the cut flowers. It is a gross feeder, requiring rich ground with plenty of sunshine and moisture. The tops of young plants should be pinched out when 5 or 6 inches high to make them throw out branches. If extra large flowers are desired, pinch off all but one flower on each branch, destroying the new buds as fast as they appear.

Price, Ist size, $25 \mathrm{c}$ each; 2nd size, $15 \mathrm{c}$ each, except where noted.

Clinton Chalfant. A magnificent golden yellow; upright dahlia-like petals, a finely rounded flower of great substance.

Dean Hole. Massive incurved flower, broad petals, exquisite form; white with beautiful shade of pink on outer side, changing to pure white with age. Strong stem, good foliage.

George W. Childs. Deep, rich, velvety crimson. A grand variety.

Gloriosum. Light lemon color, large flowers; narrow, graceful petals. Early.

Golden Wedding. Flowers very large, on stiff, erect stems; petals long, broad and channeled lengthwise. Color, bright golden yellow.

Harry Balsley. Magnificent flower; large; delicate soft pink.

Ivory. One of the best varieties for pot culture; vigorous, compact grower. Flowers pure white, of exquisite form and finish.

J. H. White. Large variety, with upright, dahlia-like petals, forming a nicely rounded flower; perfect purity of color.

Kioto. Very large, incurved yellow; strong, free grower, extra fine.

Lady Playfair. Pearly pink, deepening toward the center; incurved. Japanese; large splendid form. Very early.

Madame F. Bergmann. Finest of the early whites;

large size and excellent for pot culture and early flowers.

Major Bonaffon. Soft, clear, incurved, vellow; full to the center. Six to seven inches in diameter and nearly as deep; perfect in form and finish.

Minerva. Bold, massive flower, very large, incurved; outer petals drooping; vivid, clear yellow, extra good stem and fine foliage.

Miss M. M. Johnson. One of the best of the early vellows; color a deep, rich, golden yellow, fine large flowers.

Mrs. Minnie Wannamaker. Flowers verv large, creamy white, incurving from opening to finish, when it appears like a large snow-white ball.

Mrs. J. G. Whilldin. Handsome yellow variety of light tint, fine large size and splendid form, A magnificent addition to the scarce, very early, large flowering varieties.

Mrs. J. H. White. Large, rich, crimson variety, reverse bright gold, large reflex bloom, when fully developed showing only the crimson. Extra dwart, stiff, short-jointed stem; heavy, handsome foliage.

Mrs. Potter Palmer. Rosy pink with silvery reflex. beautifully shaped, large flowers, full to the center; outer petals reflexed to the stem with incurved tips; grow th vigorous.

Orange Queen. Color at first opening a deep bright crimson, changing to a peculiar shade of bright orange red.

Radiance. A grand medium early flowering variety; fine full, deep flowers, incurved petals, color deep golden yellow.
The Queen. Grand, pure white, of extra large size, beautiful, half-globular form, with broad incurved petals.

V. H. Hallock. Color a beautiful clear pink, deeper at the center. The petals have a solid waxy texture liarmonizing with the delicate color. Flowers large size, on stiff stems.

William Lincoln. Magnificent golden yellow variety, with straight, flat spreading petals. An extra large flower completely double.

\section{CIGAR PLANT.}

(Cuphea.) A fine new plant well adapted for general uses, as bedding, pot culture or hanging baskets. It attracts attention as a curiosity, as it resembles a miniature lighted cigar, hence its name. Tube of flower scarlet, tip white and black. Price, 1 st size, 25c each; 2nd size, $15 \mathrm{c}$ each.

\section{EUPHORBIA.}

(Snow on the Mountain.) A large, robust growing annual, with handsome, ornamental green foliage striped with clear white. A very striking plant, excellent for borders. A rapid, vigorous grower; height 2 to 3 teet. Price, 1 st size, $25 \mathrm{c}$ each; 2 nd size $15 \mathrm{c}$ each.

\section{FICUS ELASTICA.}

One of the finest plants for table or parlor decoration. Its thick, leathery foliage enables it to stand excessive heat and dryness, while its deep, glossy green leaves always present a cheerful aspect. Price, 1st size, $75 \mathrm{c}$ each; 2 nd size, $50 \mathrm{c}$ each.

\section{FUCHSIAS.}

Beautiful, delicate, wax-like flowers, exceedingly graceful in form. There are many varieties, both single and double, from which we seler: those that have proved most desirable. They are potted in rich, light soil, and should never be allowed to become "pot bound." Sprinkle often and give plenty of light and air.

\section{Price, Ist size, 25c each; 2nd size, 15c each except where noted.}

Mrs. E. G. Hill. The most perfect double white Fuchsia ret introduced; tube and sepals brizht reddish crimson, contrasting with the large pure white corolla to great advantage The plant is of splendid habit, a remarkably free grower, yet compact and symmetrical in form. Very free bloomer.

Phenomenal. Sepals bright carmine, corolla bright violet purple. Flowers very large. 1st size, $40 \mathrm{c}$ each; 2 nd size, $25 \mathrm{c}$ each.

Snow Fairy. Dwart and compact, a profuse bloomer, flowers white.

Storm King. Flowers enormous in size and very double; outside clear blush, and center rosy coral.

\section{GENISTA RACEMOSA.}

A beautiful yellow flowering plant that grows flowers freely, with little care. When well grown the blossoms literally cover the plant with a rich golden yellow mantle. This is a very popular plant for Easter decorations, at which time it is a mass of bloom. Price, 1 st size, 25c each; 2 nd size, $15 \mathrm{c}$ each.

\section{GERANIUMS.}

The most popular plants known. Ther are grown in larger quantities and spread over a larger area of country tban any other flowers we know of. They cannot be surpassed for diversity of coloring, or for gorgeous beauty or showy appearance. They glory in the heat of the summer sun, and withstand wind and drought well, but are blighted by frost. They are unequalled for bedding plants, for window boxes, or pot culture. The ease with which they are grown and the fact that they require but little care, and no special experience, recommends them for general use. Our selection comprises the very best varieties.

MEYER, IOWA, March 17, 1897

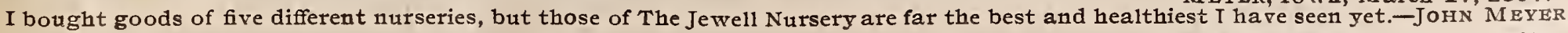

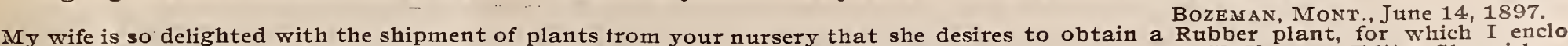
$\$ 1.00$, trusting that you will send her the best that this amount of money will buy. A. K. YERKES, Editor Chronicle. 


\section{GERANIUMS-Continued.}

Price, lst size, $25 \mathrm{c}$ each; $2 \mathrm{~d}$ size, $15 \mathrm{c}$ each, except where noted.

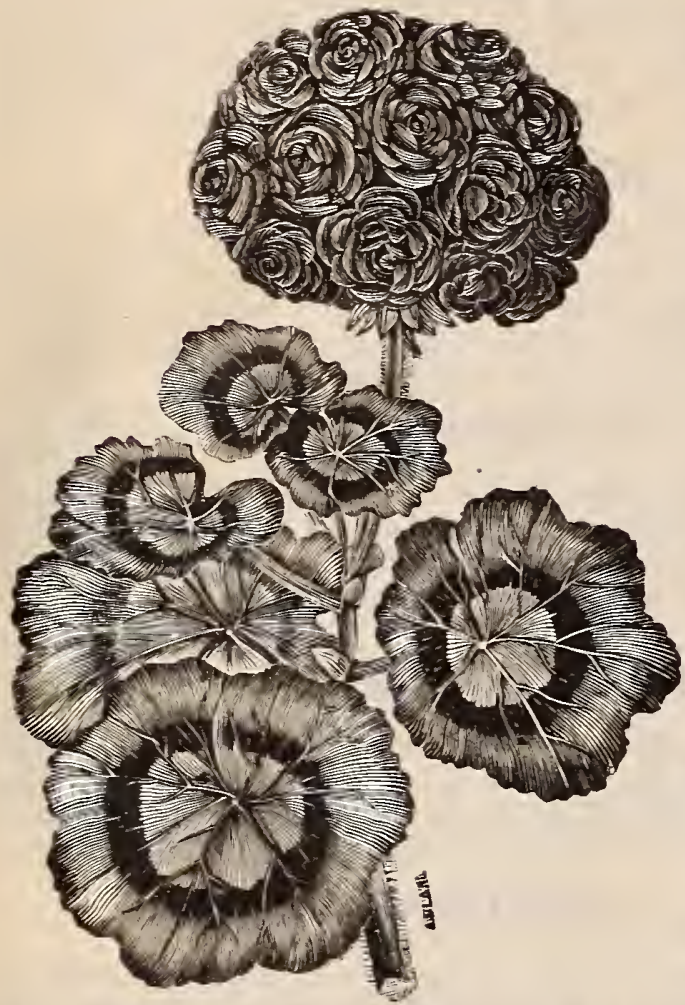

Alfred Tenny. son. Semi-double flowers of the most perfect form; truss. es large, in immense spherical balls, 6 to 8 inches in diameter, color bright scarlet orange, shaded to er $m$ il i o $n$ red. One of the finest half double sorts.

Comte de EIbe. A beautiful single shell pink, with elegant zoned foliage; is strong grower, holding the b los s o m s well above the foliage; of rather compact growth.

E. Le Gouve Very large, semidouble flowers, in immense trusses, sup ported on strong, stiff, stems. Color rich orange salmon, very distinct and fine. This is a continuous bloomer, and with care, one of the most satisfactory.

Heteranthe. Semi-double, and nne of the best of its color for a bedding rariety. Trusses exceptionally large; in color a soft shade of scarlet. One of the most popular of bedding varieties.

Ivy-Leafed. A splendid class of trailing or climbing Geraniums, adapted for baskets, vases, rock work, and trailing on trellises. They have fine; thick, glossy foliage, which of itself would be of sufficient beauty to warrant their cultivation. They bloom with the greatest freedom during spring and summer.

Lady Washington. (Pelargonium). Remarkable for their large, showy flowers, brilliancy of color, and delicate markings. Several fine named varieties.

M. G. De Meynot. A beautiful large-flowered single variety, with trusses of the largest size, well supported. In color a delicate salmon pink, with distinct white eye, upper petals shaded to white. One of the best of the single varieties.

S. A. Nutt. The flowers are of perfect shape and large size; of a deep, rich crimson, with massive trusses produced in great number. The plant has a very close, compact habit of growth. The best of the rich dark crimsons.

White Swan. Double; dwarf, bush habit, bearing a profusion of large double trusses. This variety is a valuable and useful one for association in beds, where it is desirable to mark an outline or to make a gradual descent from the tallgrowing kinds to the very dwarf varieties.

W. P. Simmons. A variety of compact, dwarf habit, and a very abundant bloomer; color bright orange scarlet. Flowers double, of grand size, set well above the foliage. Either as single plants, or associated with others, it presents a very distinct and handsome appearance.

Lemon Scented. Small, curly leaves; very fragrant.

Rose Scented. Leaves finely cut and very delicate. Rose fragrance.

Nutmeg. A spicy fragrance, similar to the nutmeg, from which it takes its name.

\section{VARIEGATED VARIETIES.}

Happy Thought. A very unique variety. The leaves hare a large cream yellow blotch in the center; the flowers are magenta rose, tinted scarlet.
Madame Saleroi. A silver-leaved variety, of rery dwarf habit and symmetrical form; it seldom exceeds a height of 6 to 8 inches. Very useful for bordering.

Mountain of Snow. Leaves bright green in the center with the outer margin deeply marked with silver white; flowers bright scarlet. It is excellent for ribbon lines, or as border around a bed of S. A. Nutt its effect is grand.

\section{STRAWBERRY GERANIUM.}

(Saxifraga) A very interesting and beautiful group of plants, with large, handsome, luxuriant foliage, and showy flowers in early spring. Strongly recommended for decorative purposes. Price, 1 st size, $25 \mathrm{c}$ each; $2 \mathrm{~d}$ size, $15 \mathrm{c}$ each.

\section{GRIVILLEA ROBUSTA.}

A beautiful and graceful foliage plant; highly ralued as a decorative plant for the table, and, when large, for tropical lawn effects. Tender perennial. Price, 1 st size, $50 \mathrm{c}$ each; $2 \mathrm{~d}$ size, $25 \mathrm{c}$ each.

\section{HIBISCUS.}

Single and double. Greenhouse shrubs with dark, glossy leaves, and large showy flowers; ex cellent for bedding out in summer. If grown in pots, will flower well in the house dur-

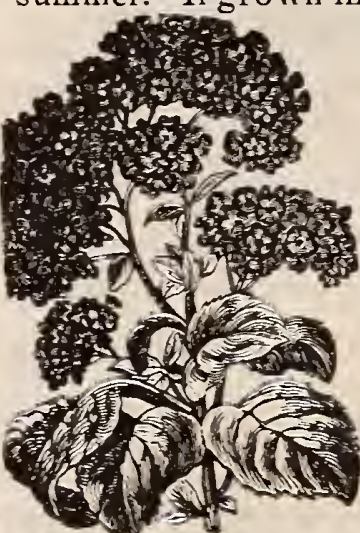

HELIOTROPE. ing winter. Its flowers are of fine form, very large, and of the most brilliant colors. Price, 1st size, $40 \mathrm{c}$ ach; 2 d size, $25 \mathrm{c}$ each.

\section{HELIOTROPE}

Well known plants grown for their exquisite fragrance. They make handsome bedding plants, and are also very desirable for house culture, a single plant filling a whole room with perfume. Purple and white.

Price, purple, 1st size, $35 \mathrm{c}$ each; $2 \mathrm{~d}$ size, 20c each. White, 1st size, 25c each; $2 \mathrm{~d}$ size, $15 \mathrm{c}$ each.

\section{HYDRANGEAS.}

\section{Price, Ist size, $40 \mathrm{c}$ each; $2 \mathrm{~d}$ size $25 \mathrm{c}$ each.}

Hortensia. A well known and favorite old plant, producing large heads of pink flowers in great profusion.

Red Branched. The smallest plants bear i $\mathrm{mm}$ en se trusses of bloom. The branches are a dark red color, brightening to a clear crimson as they near the flower heads, which are of a beautiful shade of deep rose.

Thomas Hogg.

The i $\mathrm{mm}$ en se trusses of flowers are first tinged with green, becoming of the purest white and remaining so a long time.

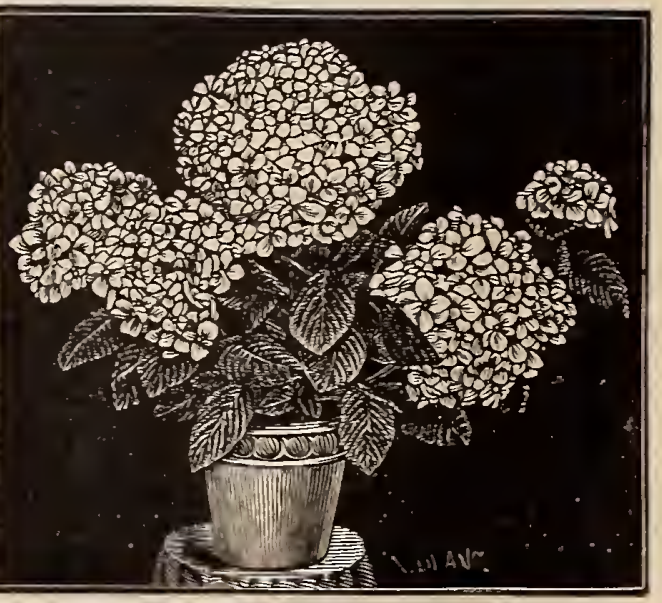

HYDRANGEA.

\section{ISOLEPIS GRACILLIS.}

A very pretty, low growing, fine, rush-like grass, cultivated for a basket plant, a purpose for which it is admirably adapted. A favorite plant for basket and greenhouse decoration. Price, 1st size, 25c each; 2d size, 15 each. 


\section{LANTANAS.}

These plants can be trained in almost any desired orm, and are almost continuously in bloom. They are of easy culture, and their free flowering qualities make them very desirable for the house. The flowers are small and in clusters. Price, 1st size, 25c each; 2d size, 15 c each.

\section{LEMON VERBENA.}

A shrubby plant, with light green, fragrant leaves, and lilactinted flowers. An old favorite. Price, 1st size, 25c each; 2d size, 15 c each.

\section{NASTURTIUMS.}

Price, potted plants, $15 \mathrm{c}$ each; seedlings, $75 \mathrm{c}$ per doz.

Dwarf. Very useful for bedding, massing or ribboning. A few Dwarf Nasturtiums in the yard are very brilliant and attractive, and are in bloom all the season. The flowers are more brilliant if the soil is not over rich. Give each plant a foot of room. Hardy; annual.

Tall. Beautiful, profuse flowering climbers of easiest culture, bearing their gorgeous flowers in profusion until killed by the frost.

\section{OTAHEITE ORANGE.}

A dwarf orange, which bears a profusion of fragrant flowers and edible fruit. One of the most effective plants for the house. Price, 1 st size, 50c each; 2d size, $25 \mathrm{c}$ each.

\section{PANSIES.}

Price, potted plants, $15 \mathrm{c}$ each, except where noted; seedlings, $75 \mathrm{c}$ per doz., except where noted.

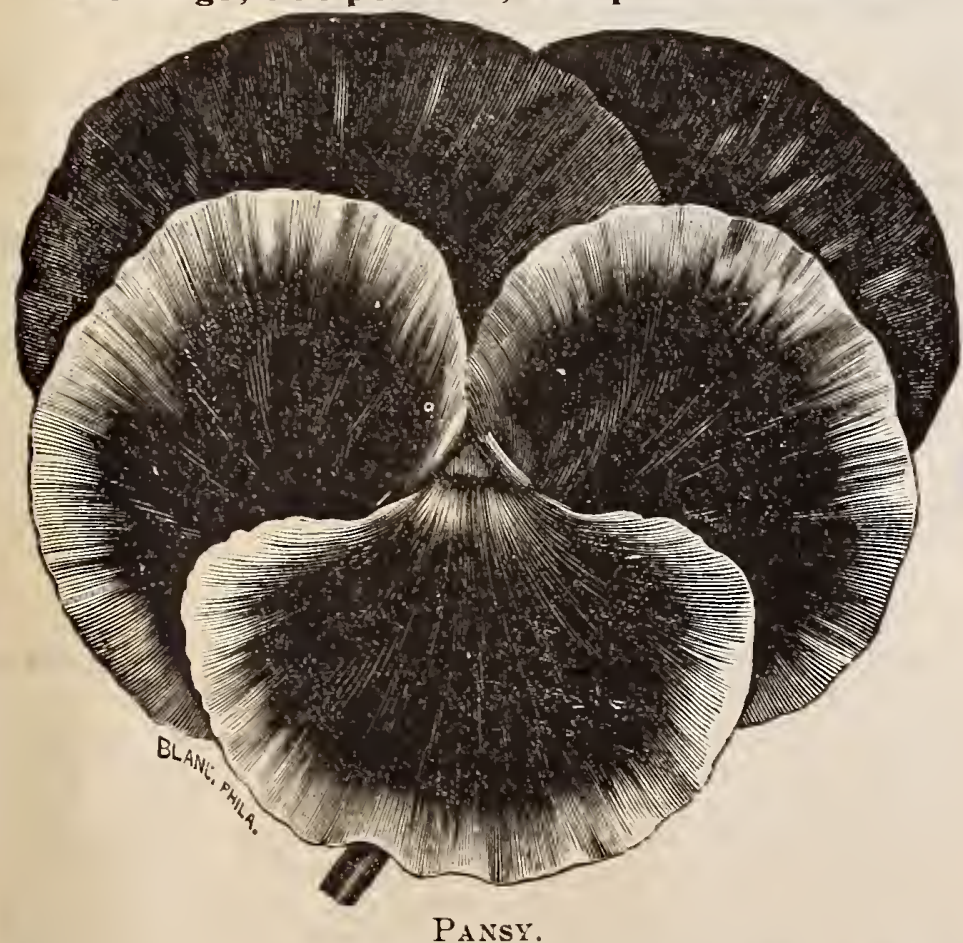

The charming beauty of the little pansy makes it a favorite everywhere. The ease with which it can be grown and the certainty of its success commend it to all. It is a plant full of surprises; new colors, new forms, new markings are constantly developing. We handle only the very best and largest flowering strains.

Mammoth Butterfly Pansy. A magnificent strain, combining all the new colorings and markings in great sizes.

Chicago Bedding Pansies. The best strain for bedding purposes. The plants are vigorous growers, even in form and elegant coloring. Flowers large, of good substance.
Giant Trimardeau Pansy. Flowers large, with a black blotch on the tliree lower petals. This old and well-known French variety is still very popular on account of its reliability.

\section{PALMS.}

The Palm stands at the head of the decorative plants. It is the personification of all that is graceful and beautiful and when established requires but little care, as they have few insect enemies and no diseases.

Areca Lutescens. One of the most valuable and beautiful Palms in cultivation. Its dark glossy green leaves are gracefully curved on slender stems, and the entire foliage is gracefully disposed. The trunk and stems are golden yellow. Price, 1 st size, $75 \mathrm{c} ; 2$ nd size, $40 \mathrm{c}$ each

Cyperus Alternifolius. (UMBRELla Plant.) Asplendidaquatic plant throwing up slender stems,

crowned with a graceful, umbrella-shaped top that for elegance and beauty cannot be excelled.

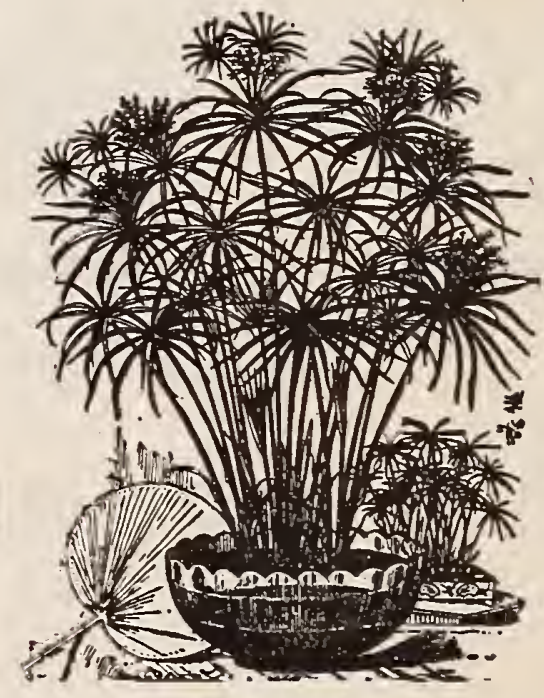

UMBRELLA PLANT.

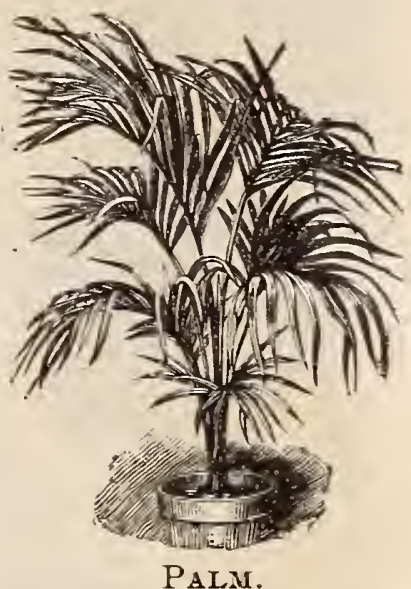
This plant thrives equally well as a pot plant, or i11 an aquarium; hence it succeeds with everybody. In rich soil it grows 3 to 4 feet high, and there is no danger of too much moisture, as it will grow, like the lily, in pure water alone. Price, 1 st size 50 c; 2 nd size, 25 c eacl.

Kentia Balmoreana. A beautiful, strong-growing Palm, with deep green, crisp foliage. A rapid grower, with a strong constitution. not easily affected by changes of temperature. Price, 1st size, $\$ 1.00$ each; 2nd size, $50 \mathrm{c}$ each.

Lantania Borbonica. This handsome Palm has tan-shaped leaves, split into divisions at the apex, and frequently there are threads hanging between the divisions. The plants will grow into
magnificent specimens in time. It is a strong, vigorous plant, and makes a fine appearance in the window, or in contrast with other plants in the greenhouse or conservatory. Price, 1 st size, $75 \mathrm{c}$ each; 2 nd size, $25 \mathrm{c}$ each.

P. Reclinata. A fine large-growing palm of easy growth and of spreading, graceful habit. One that will stand considerable neglect without much injury. Price, 1st size, $\$ 1.00$ each; 2nd size, 50c each.

P. Utilis. Frequently called the "Screw Pine," from the arrangement of its leaves. A fine indoor plant, not easily injured, and very graceful and ornamental. Price, 1 st size, $75 \mathrm{c}$ each; second size, $25 \mathrm{c}$ each.

Larger sizes will be priced on application. Remember that one year's growth increases the value of Palms almost four fold; hence large sizes are higher priced.

\section{PARIS DAISY.}

Chrysanthemum Fruteseens. This is the Daisy used so much in the gardens of Paris, and now so fashionable and in demand during the winter. It is extensively used for bouquets, as it blooms almost continuously. We have them in white and yellow blossoms. Price, 1 st size, $25 \mathrm{c}$ each; 2 nd size, $15 \mathrm{ceach}$.

WoODW ARD Ioms, April 24, 1897.

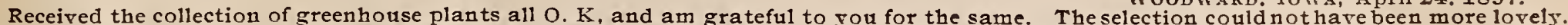
They arrived in splendid condition and have been installed "at home" with much pleasure. Please accept our thanks for same. 


\section{PRIMROSE.}

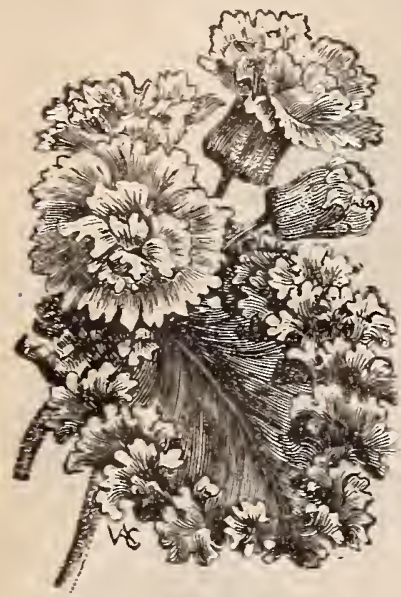

This is justly a favoritc house plant, giving universal satisfaction. They grow best in a moderately cool atmosphere, and do not require much water.

Chinese Primrose. Fine for winter blooming. Varieties in white, rose and red; double. Price, 1 st size, 25c each; $2 d$ size, 15 c each.

Obconica. Bears constantly large clusters of pale lilac flowers, of delicious fragrance. Price, 1 st size, 25c each; 2 d size, $15 \mathrm{c}$ each.

\section{SALVIA SPLENDENS.}

Large Flowering Scarlet Sage. One of the most gorgeous of annuPrimrose als, blooming throughout the summer and fall. The plants grow from 18 inches to 3 feet in height, forming dense bushes, completely covered with showy sprays of the most dazzling scarlet flowers. In the whole range of the floral kingdom there is nothing of a brighter color, or which blooms more freely. Price, 1 st size, 25c each; $2 \mathrm{~d}$ size, $15 \mathrm{c}$ each.

\section{SWAINSONIA ALBA.}

A plant which is becoming very popular for house culturc. Foliage as graceful as an Acacia; flowers pure white, produced in sprays of 12 to 20 flowers each, and resembling Sweet Peas.

It is of the eaisest culture and ever blooming. It climbs readily and is spiendid for the window garden. Price, 1st size, $25 \mathrm{c}$ each; $2 \mathrm{~d}$ size, $15 \mathrm{c}$ each.

\section{VERBENAS.}

No plant cxcels the Verbena for masses in beds. Half hardy perennials, or treated as hardy annuals, they bloom freely the first season from seed, with beautiful, dazzling, self-colored, striped, and variegated flowers. They are readily produced from seed. Price, trom seed heads, $75 \mathrm{c}$ per doz; potted plants, 10c each.

\section{Bedding plants for Lawn Ornamentation.}

Nothing adds more to the beauty of a well-kept lawn than a few nicely arranged beds of bright colored flowers. When intelligently grouped with a view to the character of the plants, and the harmony of colors, they are a joy to their owners and a pleasure to every observer; besides, they require very little labor and a small investment, and they give you constant pleasure during the whole season. Our selections are made with a view to producing the best results with a moderate expenditure. In each case the upper variety in the bracket (25 Cannas) is designed for the center, and the lower variety (50 Dark Coleus), for the border. You can select at the same price any center named and associate it with any border, if you prefer your own arrangenlent. Special prices will be quoted for larger beds, and advice and designs will be supplied free to purchasers.

\section{Our Special \$5.00 Collections of Choice Bedding Plants.}

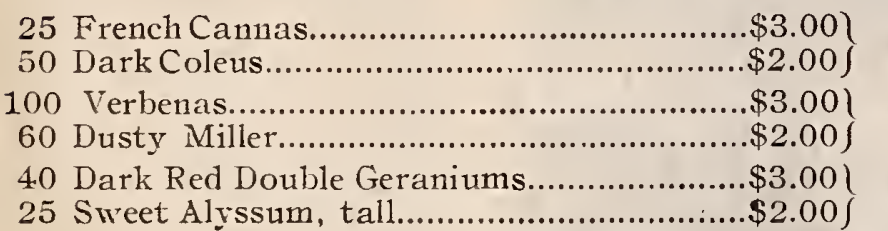

$\$ 5.00 \mid 100$ Pansies, large flowering $\$ 3.00)$

50 Sweet Alyssum, dwarf................................\$2.00

$\$ 5.00 \quad 75$ Petunias..........................................\$3.00

$\$ 2.00\}$

$\$ 5.00 \quad 50$ Achryanthes......................................\$3.00

$\$ 5.00$

$\$ 5.00$

25 Sweet Alyssum, tall

35 Yellow coleus

$\$ 2.00\}$

18 Yellow Coleus

20 Brown Coleus $\int$

35 Variegated Coleus.

\section{BULBS AND TUBERS.}

\section{ALLIUM NEAPOLITAN.}

Pure snow-white blossoms in immense trusses. Most valuablc forcutting, and very easily grown in pots or boxes. Price, 1st sizc, 15c.

\section{BEGONIA.}

Tubcrous rooted. A handsome class of summer-blooming plants, commencing to flower early and continuing in full bloom till frost, rivaling the Geraniums in depth and intensity of color. They grow best if planted in partial shade in a soil composed of leaf mould, sand, and a small portion of well rotted cow manure. They also make splendid specimen plants when grown in pots. When through flowering they should be dried off and shaken free from earth, and packed in charcoal dust or dry leaf mould, and kept in a warm place until February or March, when they may be started again. Pricc, 1st size, 25c each; 2d size, 20c each.

\section{CALLADIUM.}

Beautiful, ornamental foliage plants, especially valuable for window boxes, vases, or specimen plants. Most of the varieties succeed nicely if planted in a partially shaded border in light rich soil. Price, 1 st size, $30 \mathrm{c}$ each; $2 \mathrm{~d}$ size, $20 \mathrm{c}$ encli.

\section{CANNAS.}

Prices, Dormant roots, $15 \mathrm{c}$ each; strong potted plants, 25 c each, except where noted.

There are few flowcrs that present the striking appearance of the Canna, combining its beautiful bronze or green foliage with the splendor and brilliant colors of the flowers. This plant has received much attention from florists for the past few years, resulting in a vast improvement, entirely distinct from the old sorts. The large spikes of flowers, with tlieir gorgenus colorings of decp crimson, orange, scarlet, salmon and light yellow, make a bright aud pleasing picture for the eye. Our sclcctions comprise the best and most perfect varieties yet introduced.

Alphonse Bouvier. Onc of the grandest Cannas for out-door bedding. A luxuriant grower, frequently 6 feet in hcight. It begins to bloom early in the season and is a continuous mass of rich crimson the entire summer. The tips of the slioots are surmounted by immense clusters of bright crimson flowers of the la roest size.

Antoine Chantine. A most distinct and vigorous growing variety, bright green foliage. Very large flowers of a bright orange scarlet, overlaid with crimson. Four feet in hcight. 


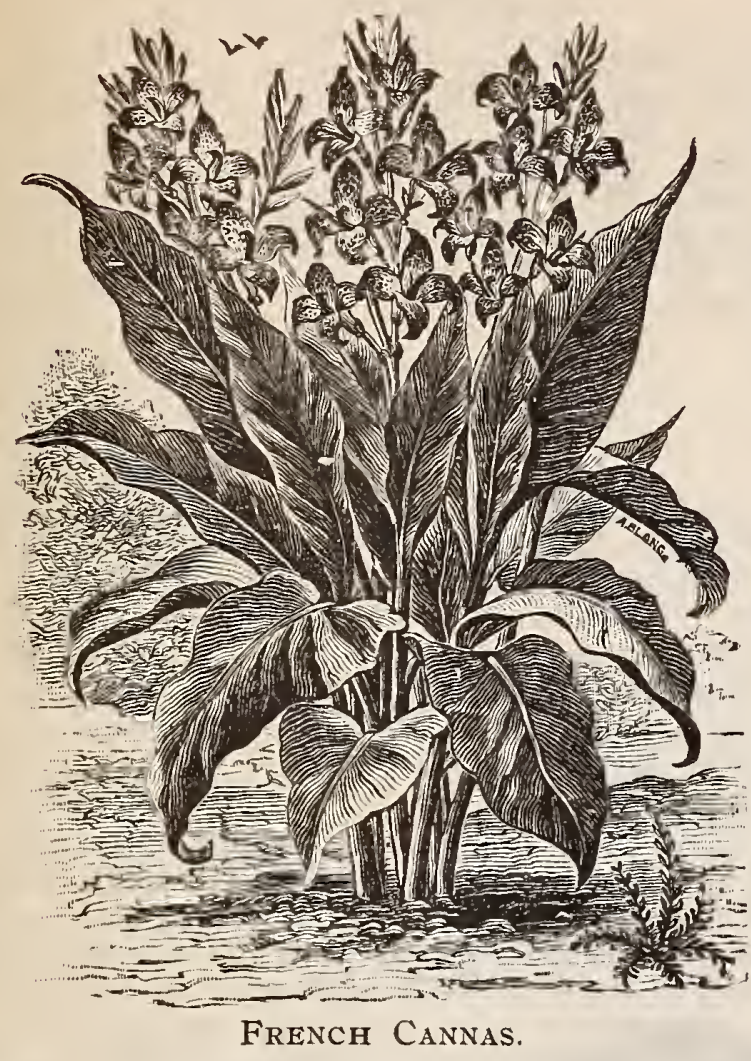

Austria. A new gaint golden lily-flowered Canna, introduced by Peter Henderson. It is indeed a giant, with flowers from 6 to 8 inches across, and magnificent in its superb grow th, often attaining a height of 6 feet. The flowers are a beautiful, soft golden yellow. A magniticent plant, in grand proportions. Price, dormant roots, $50 \mathrm{c} \mathrm{each;} \mathrm{strong} \mathrm{potted}$ plants, 75c each.

Chicago. The best vermilion scarlet to date. Green foliage, with leaves 9 to 10 inches broad, and stalk with flower truss, boldly erect. The flowers are very large, and open out nearly flat, with five petals, $1 \frac{1}{2}$ inches wide. In color a clear, deep vermilion, smooth and without markings except a rich purplish gloss. Price, dormant roots, 25c each; strong plants, 35c each.

Eldorado. A new golden yellow of the highest quality, with large flowers, born erect and well above the foliage. It is rather dwarfish in habit, $21 / 2$ to 3 feet in height, and very compact. The flowers are a rich, pure golden yellow, slightly specked with red, often measuring 4 inches across.

Felix Crouse. A strong grower, 4 to 5 feet high; foliage deep green; flower spikes very numerous; color deep scarlet.

Flamingo. As its name indicates, a deep crimson variety, with innumerable trusses, borne high above the foliage, in great profusion, from early summer till late autumn. The individual flowers are frequently four inches across, gracefully reflexed, and of elegant form. Color deep, glowing crimson. Foliage dark green, rarely over 4 feet high. A strong, vigorous grower and full of bloom. Price, dormant roots, 25ceach; stroilg potted plants, $50 \mathrm{c}$ each.

Geoffrey St. Hilaire. Rich bronze-purple foliage. Large, well-shaped flowers of rich glowing scarlet overlaid with orange. Four to 5 feet high.

Itaiia. The new giant Orchid-flowered Canıa. The richest in coloring and the grandest in its giant proportions of any of the Canna family. The growth is stately, broad and massive, and while the flowers are immense, yet they are of the most delicate and velvety coloring and marking. With all its tropical richness of color and foliage, it flourishes as does no other Canna in this climate. Italia and Austria (described above) are the grandest varieties of Cannas ever introduced. Price, dormant roots, 50c each; strong potted plants, $75 \mathrm{c} \mathrm{each}$.
J. D. Cabos. Dark geenish-maroon foliage, with a bronze inetallic luster. Flowers bright orange or apricot, sometimes brightened with a pinkish tinge. One of the most distinct of the Cannas. A fine grower, and a very early, profuse and continuous bloomer. Flowers of the largest size and of a color that is very pleasing.

Paul Marquant. One of the most pleasing and beautiful on account of its large size and distinct and novel color. The flowers stand out from the spike in such a manner as to attract special attention. Color a beautiful shade of bright salmon with a carmine tint.

Queen Charlotte. A splendid, gilt-edged variety, considered the best by many. The flowers are very large, are borne in immense heads, well above the dark green foliage, and are a clear orange scarlet, deeply edged with a bright canary yellow. A perpetual bloomer, and one of the finest decorative plants. Price, dormant roots, $25 \mathrm{c}$ each; strong potted plants, 50c each.

Souv. Antoine Crozy. A magnificent gilt-edged variety. Flowers large, with well-rounded petals of the most i11tense scarlet crimson, bordered with a broad band of rich golden yellow. Trusses large, erect and loaded with bloom, nearly every flower stalk carrying two perfect spikes.

Star of '91. Habit of plant very dwarf, but with full, fine foliage. It has a persistent habit of throwing up fresh stalks from the base, each stalk producing a flower-spike, with several branches, each branch bearing from 12 to 15 flowers, 3 to 4 inches across. The color of the flower is a glowing orange scarlet, faintly banded with a golden yellow. A perpetual bloomer, and an excellent pot or tub plant.

\section{CYCLAMEN PERSICUM.}

These are among the most beautiful winter and spring flowering plants for the window and greenhouse. Not only arc the flowers of striking beauty, but the foliage is highly or11amental. The colors range through shades of pink, crimson, white, spotted, etc. Most of them are delicately fragrant. Price, 1st size, 35c each; 2d size, $25 \mathrm{c}$ each.

\section{FREESIA.}

Most interesting and beautiful. Thcy give forth an exquisite fragrance and are very desirable as a cut flower. When kept in water they will remain in good condition for two weeks. Flowers are pure white with a yellow blotch on the lower petals. For a succession of blooms, plant every two weeks. Price, 5c each; 30c per doz.

\section{GLOXINIA.}

Most charming plants of a dwarf habit. Their flowers arc produced in the greatest profusion and are of the 1nost exquisite and gorgeous colors, many being magnificently spotted, mottled and blended. Under the commonest culture they bloom continuously for weeks. Price, 1 st size, 40c each; $2 \mathrm{~d}$ size, 25 c each.

\section{HYACINTHS.}

The most beautiful, fragrant and popular of the Dutch bulbs and particularly adapted for house culture. It has a wonderful diversity and purity of color. Its beautiful wax-like flower and delightful fragrance, together with its ease of culture, make it the flower of the masses. Single Hyacinths, blue, red, rose and white flowered; Double Hyacinths, blue, red rose and white flowered; Roman Hyacinths, blue, red, rose and white flowered. Price, Dry Bulbs, 1st size, 25c each; 2d size, 15c each; strong, potted plants, $40 \mathrm{c}$ each.

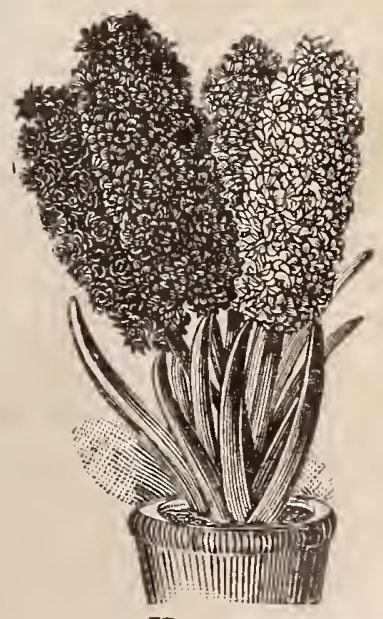

HY А İNT⿱中⿰㇀丶 


\section{OXALIS.}

Beautiful for borders and edgings and also fine for hanging baskets in winter.

Rosea. Large, pink flowers.

Yellow. A new variety with large, yellow blossoms, quite fragrant. Price, 1 st size bulbs, $15 \mathrm{c}$ each.

\section{STAR OF BETHLEHEM.}

A beautiful variety, valuable for forcing purposes. It throws up a spike which is surmounted by a number of large, pure white, star-shaped flowers, which have a distinct black center. They are also somewhat fragrant. Price, 1st size bulbs, $15 \mathrm{c}$ each; $\$ 1.00$ per doz.

\section{TUBEROSE.}

One of the most delightfully fragrant and beautiful of the summer flowering bulbs, throwing up tall spikes of double white flowers, 3 feet high, which remail in bloom a long time. For early flowers they can be started in February or March in the greenhouse or hot bed, and for a succession they can be planted at intervals as late as August. For flowering in the open border, plant about the first of May. Price, 1st size, 15c each; $\$ 1.00$ per doz.

\section{TULIPS.}

Extra fine named varieties for forcing or bedding.

Price, Dry Bulbs, 2 for $15 \mathrm{c}$, or $60 \mathrm{c}$ per dozen, except where noted.

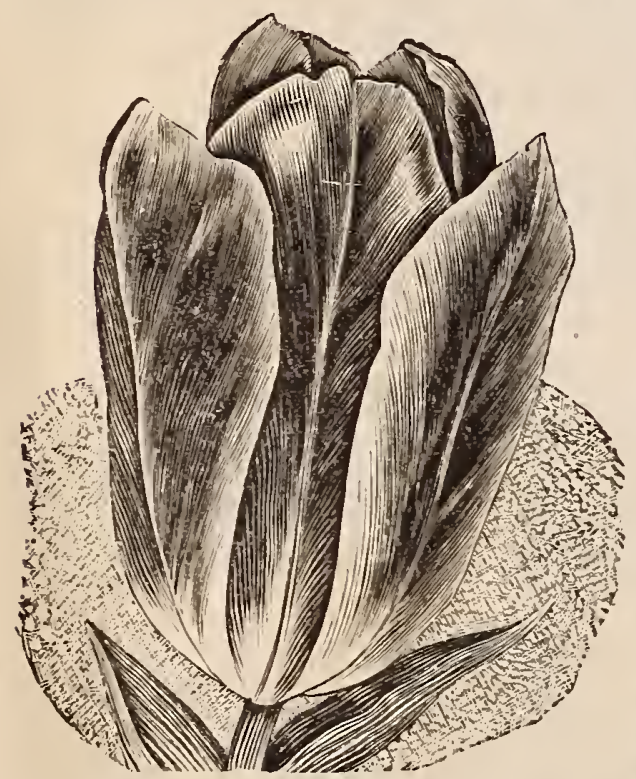

Double Mixed Tulips. These bloom a little later than the single varieties. The flowers are larger,and, being double, last longer in bloom than the single kinds. The single and double varieties planted in beds together lengthen the flowering season, and make beautiful combinations. When desired, we will make assortments of single and double at the same prices.

\section{Double Named Tulips.}

La Candeur. Pure white.

Turnesol. Scarlet; yellow edge.

Yellow Rose. Bright yellow.

Murillo. Rose and white; very large and fine.

Rex Rubrorum. Bright crimson scarlet.

Gloria Solis. Crimson; vellow margin.

Mixed Parrot Tulips. Late single Tulips, of large size and most peculiar shape, very singular and striking; a great curiosity as well as very beautiful. Finest mixed colors.

\section{Parrot Tulips in Separate Colors.}

Lutea Major. Yellow. Rubra Major. Large dark rcd. Gloriosa Perfecta. Red and Yellow.

Admiral of Constantinople. Red.

Single Mixed Tulips. For beauty of form and brilliancy of color these early single and double Tulips cast all other spring flowers in the shade. Nothing can equal, much less cxcel, their gorgenus appearance in beds, lines, ribbons or groups in the spring garden, to which they impart as gay and rich $d n$ appearance as the finest summer bedding plants.

\section{Single Named Tulips.}

Duc Von Thol. Intense brilliant scarlet.

Kaiser Kroon. Brilliant scarlet, deeply cdged yellow. Price, $15 \mathrm{c}$ per bulb.

La Reine. Blush white.

Pottebaker White. Pure white.

Cottage Maid. White with rose edge.

Canary Bird. Pure yellow.

Proserpine. Rose carmine.

\section{LILIES.}

\section{CALLA.}

The well-known Lily of the Nile. This is a fine house plant, and will bear much neglect if given plenty of water when growing. Should be rested in May and June by laying the pot on its side in the shade.

White Calla Lily. Pure white, large, splendid flower. Price, 1st size, 25c; 2d size, 15c.

Spotted Calla Lily. Dark green leaves, beautifully spotted with white; purple throat. Price, 1st size, 30c each; $2 d$ size, 20c each.

Little Gem Calla Lily. This variety rarely exceeds 12 inches in height. The flowers are correspondingly smaller than the tall growing sorts, and are useful for loose bunches and bouquets of flowers. It is far superior to the tall-growing variety as a house plant. Price, 1 st size, $25 \mathrm{c}$ each; $2 \mathrm{~d}$ size, $15 \mathrm{c}$ each.

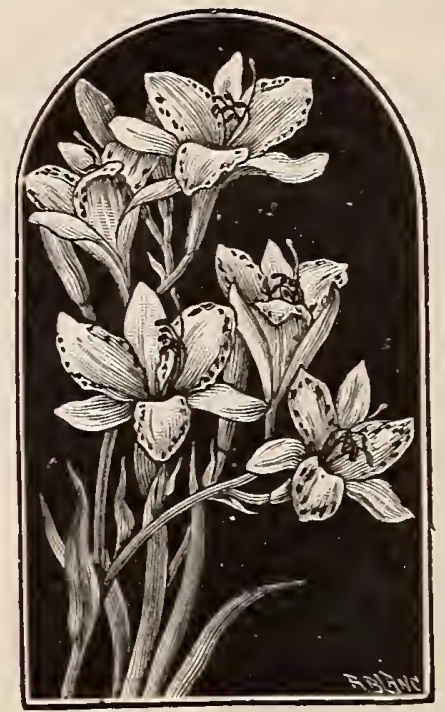

Chinese Sacred Lily. The sacred flower of China. The Joss Hower, or "Flower of the Gods," and considered by the Chinese to be an emblem of good luck. This is a variety of the Polyanthus or many flowered Narcissus, grown in China, where they attain great size and strength, insuring luxurant growth and remarkable profusion of bloom in a very short period. The bulbs bloom in 6 or 8 weeks after planting, throwing up several flower stalks, thickly studded with bloom. White, with yellow center; very fragrant. They are flowered in shallow ornamental bowls containing water and pebbles to keep them from upsetting when in bloom. Price, 1st size, $40 \mathrm{c}$ each; $2 d$ size, $25 \mathrm{c}$ each.

L i 1 i $\mathbf{u}$ m C andidum. (All Saints' Lily.) The well-known garden Lily, witb snow-white fragrant blossoms. Should be planted in the fall, or potted plants may be secured for spring blooming. Price dry bulbs, 1 st size, $40 \mathrm{c}$ each; $2 \mathrm{~d}$ size, 25 c cach.

Spider Lily. A bulbous plant belonging to the Amaryllis family; of the easiest culture, producing large clusters of beautiful pure white flowers very freely; giving a succession of bloom all summer. Delightfully fragrant. Price, Ist size, $40 \mathrm{c}$ each; $2 \mathrm{~d}$ size, $20 \mathrm{c}$ each.

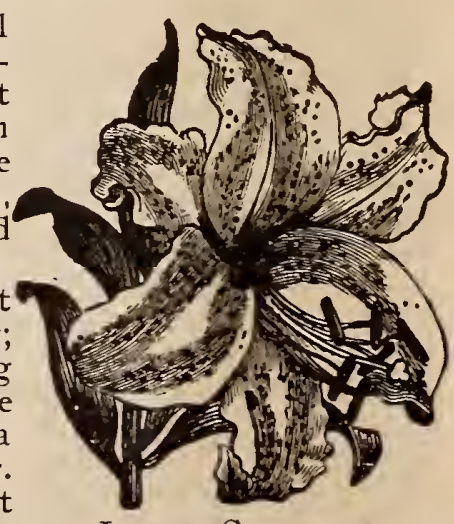

Lilium Candidum.
Easter Lily. (Lilium Harissii). The true Bermuda Easter Lily; flowers delightfully fragrant, pure waxy white and of great substance. The best forcing Lily for the louse. They can be grown out of doors if covered well. Price, 1st size, 40c each: $2 \mathrm{~d}$ size, $25 \mathrm{c}$ each. 


\section{FERNS}

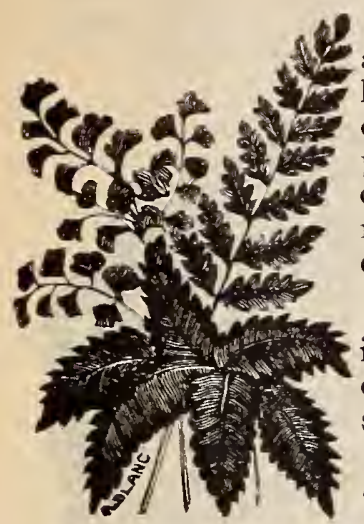

Are becoming very popular, not only on account of their beauty and graceful habit, but for decorative work, and as an ornament for the table they are not surpassed by anything we know of. Their culture is simple, plenty of water at the roots, never allowing them to completely dry out.

Adiantum Cuneatum. Beautiful; its delicate fronds being much used with cut flowers. Price, 1st size, 30c each; 2d size, 20c each.

Adiantum Cuneatum Gracillimum. The finest species among the Adiantums; foliage very delicate. Price, 1 st size, $30 \mathrm{c}$ each; $2 \mathrm{~d}$ size, 20 ceach,

Asplenium Diversifolium. A very graceful fern; makes a fine specimen plant. 1st size, $25 \mathrm{c}$ each; $2 \mathrm{~d}$ size, $15 \mathrm{c}$ each.

Nephrolepsis Bostoniensis. This is a beatititul, slender growing variety with long fronds. It is grown extensively in the vicinity of Boston, and has become very popular and in great demand. It is commonly called the Boston Fern. Price, 1 st size, $60 \mathrm{c}$ each; $2 \mathrm{~d}$ size, $40 \mathrm{c}$ each.

Nephrodium Molle. A very beautiful Fern of graceful, drooping habit and easy culture. Price, 1st size, 25c each; $2 \mathrm{~d}$ size, $15 \mathrm{c}$ each.

Pteris Tremula. One of the finest for house decoration. Price, 1 st size, $30 \mathrm{c}$ each; 2 d size, $15 \mathrm{c}$ each.

Pteris Umbrosa Cristata. A strong growing variety, very suitable for jardinieres and table decoration. Price, 1st size, 25c each; $2 \mathrm{~d}$ size, $15 \mathrm{c}$ each.

Sword Fern. A very graceful fern with long sword-like fronds; very ornamental. Price, 1st size, 25c each; 2d size, $15 \mathrm{c}$ each.

\section{CLIMBING VINES.}

The graceful outlines and delicate foliage of the various climbers make them very desirable. Many of them are valuable for their beautiful flowers, and all are ornamental and easy to grow.

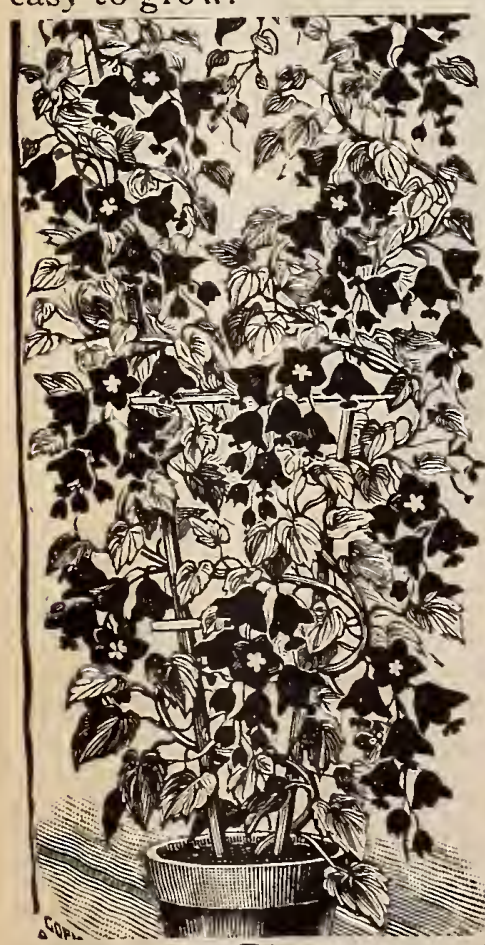

lpomea. (Moon Flower.) A plant that grows and blooms well with every one. If planted in rich ground where it has full exposure to the sun, it will attain a height of 40 feet by the middle of October, blooming abundantly the entire season. The flowers are pure white, from 5 to 6 inches in diameter emitting a rich jessamine odor at night. They begin to open about sundown and close before noon the following day. Price, 1 st size, $30 \mathrm{c}$ each; $2 \mathrm{~d}$ size, $15 \mathrm{c}$ each.

Maurandia. This plant should be grown in the hotbed or greenhouse. They are graceful climbers, making a growth of 5 to 6 feet, with abundant foliage. Flowers are of good size and form, of different shades of blue, white and rose. Good for baskets or vases. Price, 1 st size, $25 \mathrm{c}$ each; $2 d$ size, 15 c each.

Asparagus Plumosus. A beautiful climbing plant with bright green, gracefully arched foliage, surpassing Maidenhair Ferns in grace, delicacy of texture and richness of color. Price, 1 st size, $40 \mathrm{c}$ each; $2 \mathrm{~d}$ size, 25c each.
Cobea Scandens. A beautifnl climber of rapid growth large purple bell-shaped flowers. For coyering arbors, trellises, etc., it is indispensable, as its dark green foliage and showy flowers make it very attractive. Price, 1st size, 25c each; $2 d$ size, 15 c each.

Myrtle (Vinca). A well known hardy, herbaceous, trailing plant much used in cemeteries for covering graves. The deep green of the leaves makes a beautiful contrast with the delicate blue flower. If planted 18 inches apart, they will soon completely cover the ground. They bloom very early in the spring, bearing a beautiful blue flower. Price $25 \mathrm{c}$ each.

Passion Flower. A beautiul class of rapid growing climbing plants, well adapted for house culture in winter, or for training over porches, etc., during summer. Price, 1st size, $25 \mathrm{c}$ each; 2d size, $15 \mathrm{c}$ each.

Pothos Aurea. A genus of climbing plants, having very handsome foliage, grown in the greenhouse for the sake of their leaves. The beautiful variegated species known in culti vation as Pothos Aurea is undoubtedly the best of this class. Price, 1st size, 35c each; 2d size, 20c each.

Vinca Variegata. Rapid grower; leares glossy green, marked white. Price, 1 st size, 25c each; 2d size, 15c eacli.

\section{ROSES.}

The Rose is recognized as the "Queen of Flowers" and no garden is complete without it. No other flower known presents so wide a field of beauty and such diversity of hues. Our list comprises the best selections for outdoor and indoor cultivation. Some varieties are used for both purposes, and to these we attach prices for 2-year full grown plants, and for potted plants. All the Roses we list are on their own roots, and should the top be injured, they will come from the root again, true to name-a great advantage. All our plants are strictly first-class in every respect. Hybrid Remontant, or Perpetual Roses, bloom continuously from June to Octoher out of doors, and if grown indoors, bloom from November to June, thus giving a succession of flowers all the year.

\section{HYBRID REMONTANT, OR PERPETUAL ROSES.}

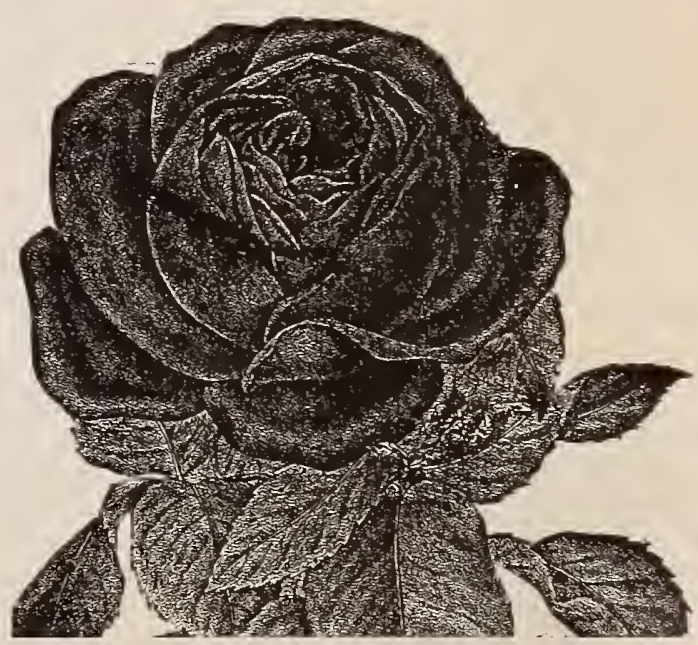

General JacQueminot.

Price, 2-year plants, 1st size, 50c each; 2 d size, $25 \mathrm{c}$ each; potted plants, $15 \mathrm{c}$ each, except where noted.

Alfred Colomb. Brilliant carmine or erimson; very large, full, and of fine globular form; extremely fragrant, and, in every respect a superb sort. Green wood, with occasional pale greenish thorns; foliage large and handsome. One of the most useful for general cultivation.

American Beauty. A strong, vigorous grower, a continuous bloomer; the flowers are large in size, of a deep rose color, and delightfully fragrant. Price, 2-year field plants, $75 \mathrm{c}$ each; strong potted plants, 1 st size, $50 \mathrm{c}$ each; $2 \mathrm{~d}$ size, $25 \mathrm{c}$ each.

GLENCOE, MaY 1, 1897.

The Roses and Trees were all received in good condition. The plants were all nice and fresh. We were more than pleased with them Thanking you most heartily, I remain, 


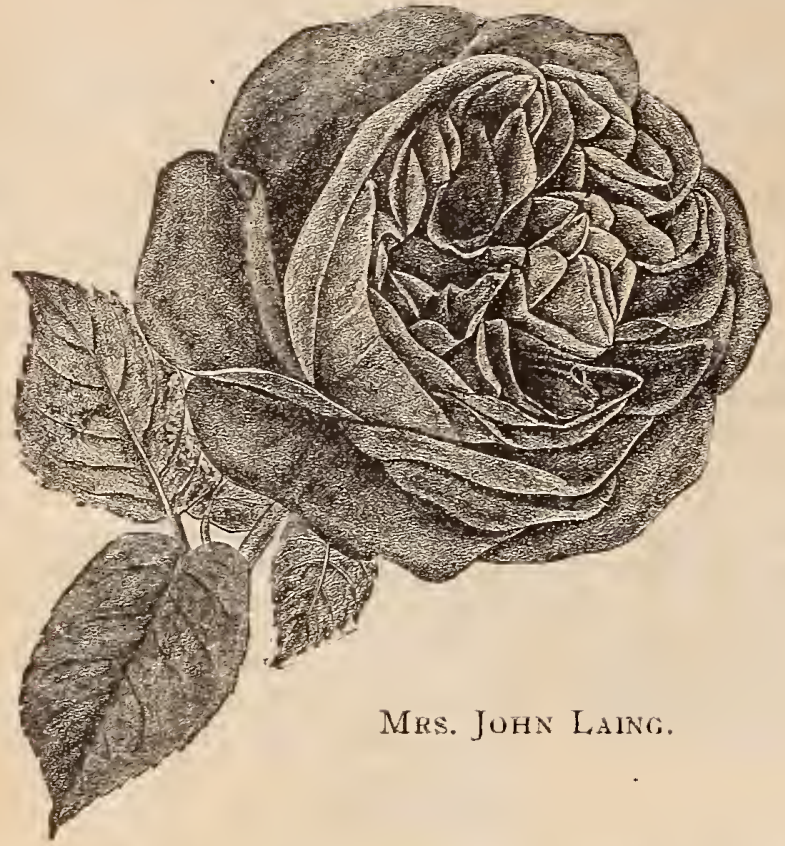

Anne de Diesbach. Glory of France. A beautiful shade of carmine; very large. A superb garden sort, fragrant; one of the hardiest. Valuable for forcing.

Countess of Oxford. Bright carmine, fading in the sun; very large and full, not fragrant, wood almost thornless; foliage very handsome, large and distinct; fine in the bud. Valuable for forcing.

Fischer Holmes. Deep glowing crimson; large, moderately full, and of imbricated form. A superb rose.

General Jacqueminot. Brilliant crimson; not full but large and extremely effective, fragrant and of excellent hardy habit. Forces well.

Henderson's Jubilee. A true Hybrid Remontant; per fectly hardy, blooming throughout the summer and fall; very strong grower; dark green foliage, short jointed with long flower stenis. The flowers are very large, sometimes measuring 6 inches across, and are a pure red, shading to a deep crimson, toned to a velvety maroon red in the depth of the petals. "It fairly glows in its rich depth of color." A grand garden rose. Price, 2-year plants, $\$ 1.50$; potted plants, 1 st size, $\$ 1.00$ each; 2 nd size, $75 \mathrm{c}$ each.

Jean Liabaud. Crimson maroon, illuminated with scarlet; large, full and fragrant. A very beautiful dark rose.

John Hopper. Bright rose with carmine center, large and full. A profuse bloomer and a standard sort.

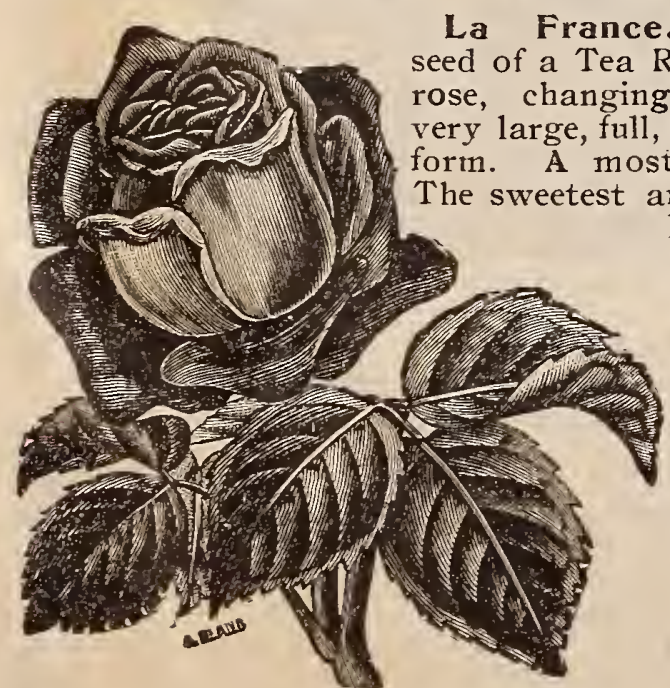

LA FRANCE
Mrs. John Laing. A seedling from Francois Michelon; soft pink; large and of fine form, produced on strong stems; exceedingly fragrant; one of the most valuable varieties for torcing, and flowers continuonsly in the open ground. The most beautiful rose of recent introduction.

Paul Neyron. A seedling from Victor Verdier fertilized by Anne de Diesbach. Deep rose color, good. tough toliage, wood rather smooth; by far the largest variety in cultivation. A free bloomer. Very desirable as a garden rose; valuable for forcing.

Victor Verdier. Bright rose with carmine center, a very fresh shade of color; not fragrant; free bloomer; wood nearly smooth. This variety with its numerous progeny is more tender than any of the other types in the class. A beautiful rose.

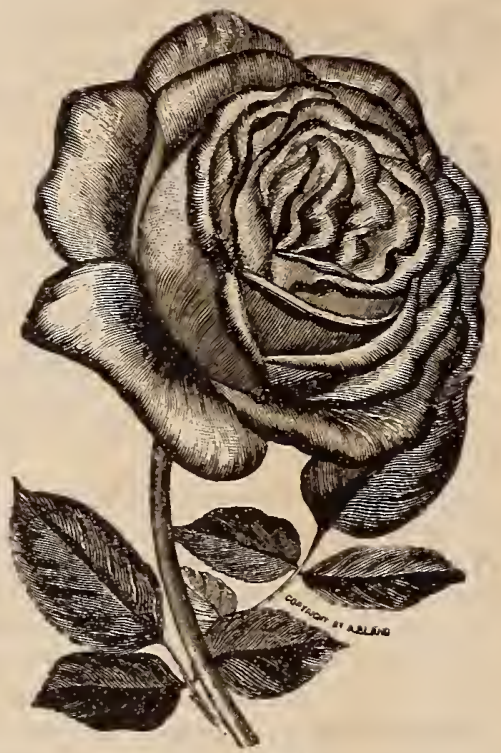

PAUL NEYRON.

\section{TEA ROSES.}

Bride. A lovely, pure white Tea Rose of large size. Admirable for forcing as well as for summer flowering. The buds have more substance than the Niphetos, are full and double, and possess all the good charteristics of the Catherine Mermet.

Catherine Mermet. Bright pink center, shading to light creamy pink. Lovely, large pointed buds. A popular variety.

Clothilde Soupert. Flowers of medium size, very double and beautifully formed, oval at first but flattening as they expand. Color pearly white atouter edge, shading to a center of rosy pink, sometimes varying in color to nearly pure white. Very fragrant and a constant bloomer. A superb variety.

Duchess of Albany. A sport from the popular La France. While it resembles the parent in many respects, it is distinct in color; it is a deep

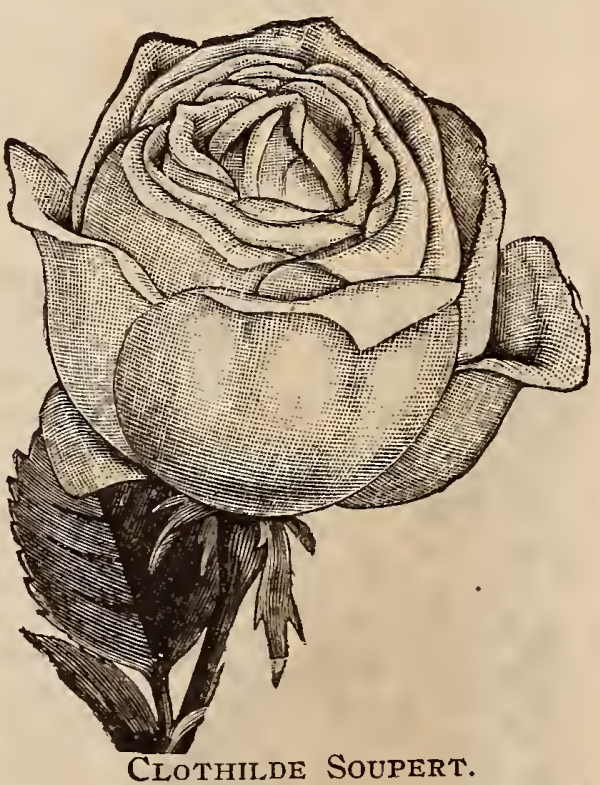
rich pink, fine form, very vigorous, free blouming and fragrant.

Kaiserin Augusta Victoria. A soft, pearly white bybrid Tea Rose, tinted with lemon center; remarkably fragrant; a strong, vigorous grower with beautiful foliage. A free bloomer, with beautiful, perfectly shaped flowers, borne in profusion on long, graceful stems that make it particularly valuable for cut flowers. This new rose is one of the best. Price, 1st size, $50 \mathrm{c}$ each; 2 nd size, $25 \mathrm{c}$ each.

Papa Gontier. This is now one of the most popular roses. It is a strong grower and a profuse bloomer. Flowers large, purest white, and of most perfect form, both in bud and when fully opened. One of the most satisfactory roses for bedding, producing its lovely buds and flowers throughout the season. should be in every collection.

Eit WORTh, Iotva, May 7, 1897

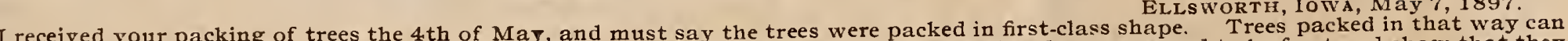

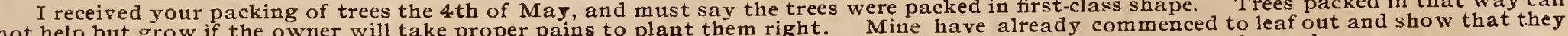
not help but grow if the owner will take proper pains to plant them right. 


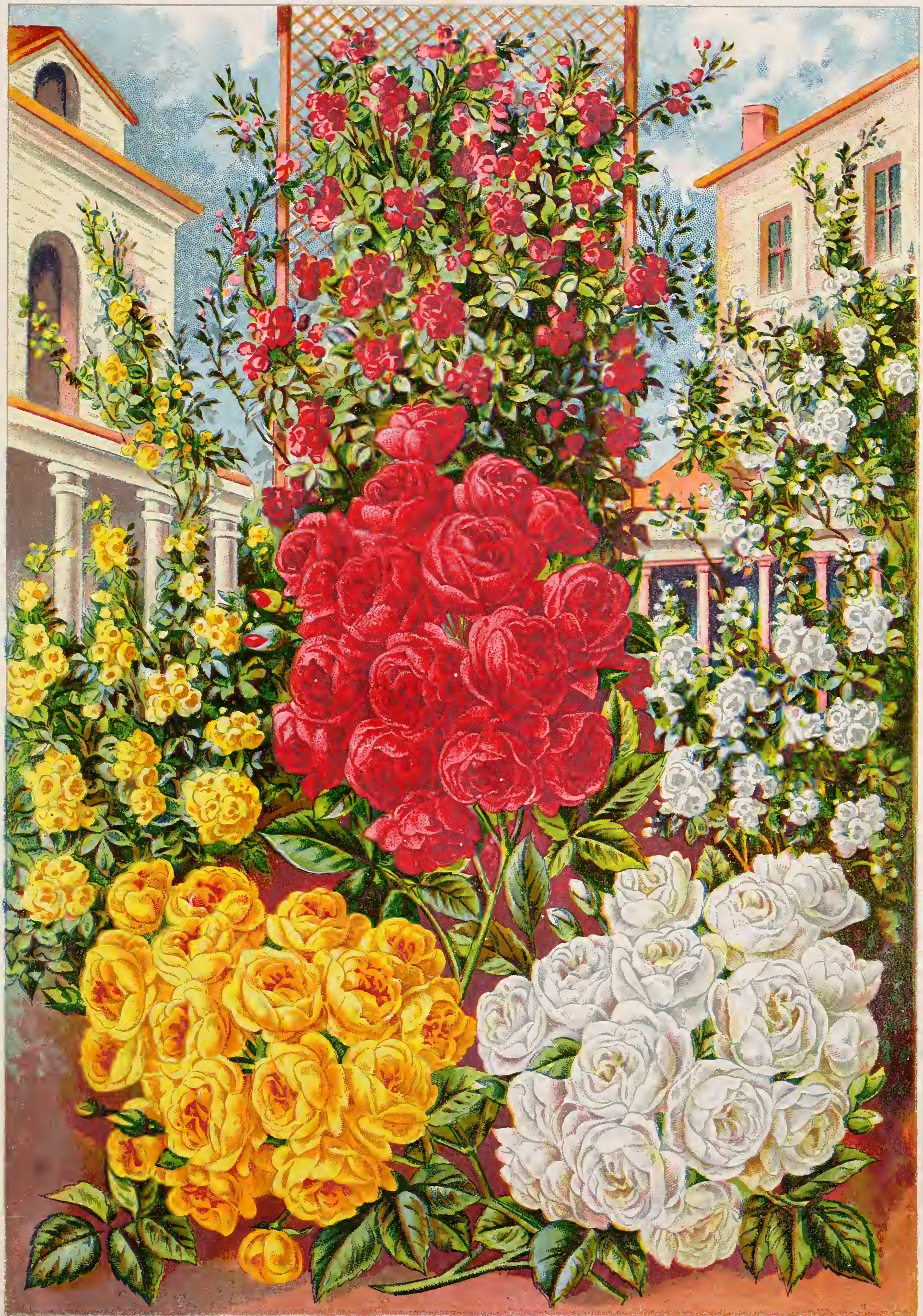

The Three (limbing Ramblers

Yellow. Crimson and Whito 
This grand rose improves upon acquaintance; the better it becomes known the more popular it is. It is of rapid, vigorous growth. The flowers are produced in trusses, pyramidal in shape, good specimens measuring 9 inches from base to tip and 7 inches across, fairly covering the plant from the ground to the top, so that it is one mass of glowing crimsor. The color is superb and remains strong and vivid to the end; plants in our ground retain the bloom for two months. The profusion of bloom is marvelous, over 300 blossoms having been counted on one shoot. It is essentially a Garden Rose, but makes a magnificent specimen in a pot or tub. There was recently exhibited in Boston a "Crimson Rambler" growing in a 12-inch pot, the plant being about 4 feet high and 3 feet wide, bearing nearly 5,000 buds and flowers. It is adapted to the entire country, and should be in every garden in America.

Price, 2-year plants, 75 cents each; potted plants, Ist size, 50 cents each; $2 \mathrm{~d}$ size, 25 cents each.

\section{THE YELLOW RAMBLER (Aglaia).-}

After repeated efforts, we have that happy combination of the climbing habit and yellow coloring with a hardiness that warrants its introduction. Rose growers have been striving to secure a rose of this character for years and the "Yellow Rambler" represents the most complete success yet attained. It has been exposed to a continuous temperature of zero, and even below that, with no protection, thus proving itself the hardiest yellow rose known. By laying the plants down in the winter, it can be successfully grown here in the extreme north, and it is well worth the slight effort required to protect it. The flowers are borne in immense clusters (like the Crimson Rambler) often as many as 150 blossoms in a single bunch.

The color is a clear bright yellow in the bud, changing to a beautiful creamy shade when fully expanded. The blossoms have a very agreeable, delicate fragrance and last from three to four weeks without fading. Its vigorous growth (frequently 8 to 10 feet in a season), immense productiveness and wonderful beauty, make it a favorite.

Price, 2-year plants, 75 cents; potted plants, ist size, 50 cents each; $2 \mathrm{~d}$ size, 25 cents each.

\section{WHITE RAMBLER (Thalia.)-}

This variety is a fitting companion for the Crimson Rambler, closely resembling it in vine and foliage, as well as in the great clusters of pure white flowers, which are deliciously fragrant. The flowers remain on the plant a long time-from three to five weeks-and keep a long time when cut. The plant is perfectly hardy, equal in this respect to the Crimson Rambler, and where one is planted the other should be also. By growing this in a pot and training it to a pyramidal trellis, a fine plant may be had in bloom for Easter.

Price, 2 year plants, 75 cents each; potted plants, Ist size, 50 cents; 2 d size, 25 cents each.

A COMBINATION

of "The Three Ramblers" produces the most beautiful effect that can be imagined. The interlacing branches bearing the great pyramidal clusters of red, yellow and white roses, relieved by the delicate green of the foliage, commands the unbounded

admiration of the observer.

Price, one each of the three Ramblers, 2 -year old, $\$ 2.00$; the same set in potted plants, ist size, $\$ 1.25 ; 2 \mathrm{~d}$ size, 65 cents.

\section{A FEW SUGGESTIONS :-}

There are many ways in which climbing roses may be used to ornament the home grounds, rendering them handsome and attractive at a trifling cost, and at the same time they provide a profusion of beautiful cut flowers to decorate and embellish the table, in fact, the whole interior of the house. Instead of running a fence across the lot, put up a little poultry netting, and plant a few of each color of the Rambler roses and in a very short time it will be covered with an array of bright green foliage, brightened by the brilliant colors of the blossoms. A screen made of a few stakes and a rod or so of poultry retting may be made to cover an unsightly object and add a beautiful feature to your lawn. All this at the cost of only a few cents and a little time that cannot possibly be better employed.

These are only a few of the many suggestions for the use of Roses that come to us.

DOES IT INTEREST YOU?-

Drop us a line and tell us what you want and we will gladly give you the benefit of our long experience in growing roses, vines, trees, etc. We will tell you what to plant, what to avoid, how and when to plant, and how to take care of your plants, trees, shrubs, etc., so as to become successful with them. Do not be afraid to ask questions ; it's our business to answer them to the best of our ability, and we enjoy it. You may rely upon our very best efforts to serve you faithfully, and your order, whether large or small, will have our most careful attention. We WARRANT all our goods to reach our customers in good condition for planting.

Address

\section{THE JEWELL NURSERY COMPANY,}

Lake Cíty, Minn. 
Sunset. A sport from the well-known and popular old Perle des Jardins, which it resembles in everything except color, being a beautiful saffron or apricot, tinted with orange. Price, 1st size, potted plants, $30 \mathrm{c}$ each: 2 nd size, $15 \mathrm{c}$ each.

Sweet Briar. Valuable for the refreshing fragrance of its leaves. This is the true Eglantine. No garden should be without a plant of it. It is perfectly hardy, and once it is planted, little, if any, care is necessary. It is splendid as a hedge, or equally good as a group on the lawn, or a single specimen in

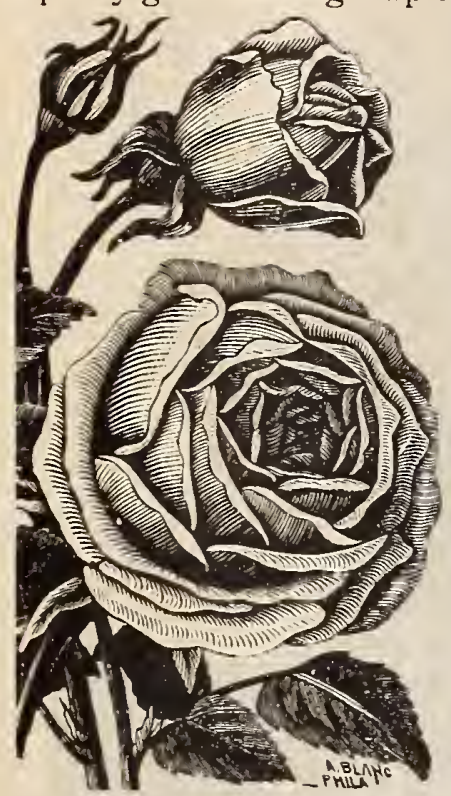

PERLE DES JARDINS. the garden. It does well either in the sun or sliade. Price, 2-year plants, 75 c each; potted plants, 1 st size, $50 \mathrm{c}$ each; 2 nd size, $25 \mathrm{c}$ each.

Perle des Jardins. Very large, full and finely formed, color rich golden yellow, very closely resembling the Mareschal Neil in size and color. The most popular yellow rose in cultivation.

Souv. de President Carnot. A new Hybrid Tea of the greatest promise. The growth is vigorous, with dark green foliage, but its glory is in its flower. It is very large, both in bud and expanded blossom, double to the center and opens perfectly. In color a rosy flesh tint, very soft at the center, and shaded lighter toward the ends of the petals. The bud is very long and very full at the base. Price, potted plants, 1st size, $50 \mathrm{c}$ each; 2nd size, 25 c each.

\section{FIELD OR OUTDOOR ROSES.}

We grow a full line of outdoor roses, some of which need tro protection and many of them require only a slight covering in the fall, in return for which they give an abundance of beautiful and fragrant blossoms, and are a source of nnbounded pleasure. Many of the varicties named in our Greenhouse collection are also grown as field Roses, and we name them here, but for descriptions see preceding pages. Price, first-class 2 -year plants, 50c each, except where noted.

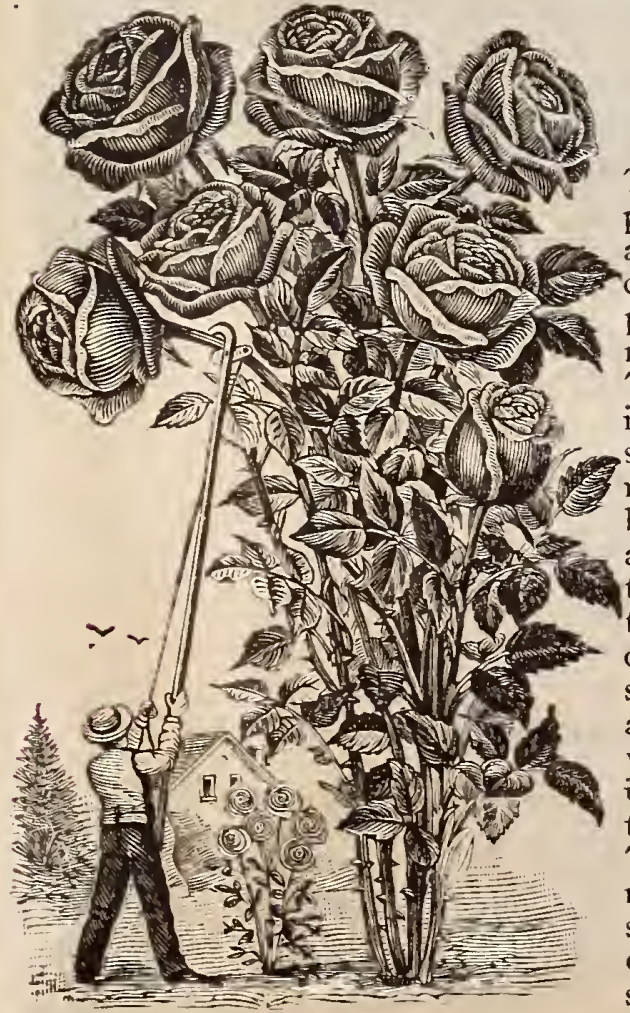

\section{CLIMBING ROSES.}

Crimson $\mathrm{R}$ ambler. This grand Rose improves upon acquaintance; the better it becomes known, the more popular it is. It is of rapid, vigorous growth. The flowers are produced in trusses, pyramidal in shape, good specimens measuring 9 inches from base to tip and 7 inclies across, fairly covering the plant from the ground to the top, so that it is one mass of glowing crimson. The color is superb and remains strong and vivid to the end; plants in our grounds retained the bloom for 2 months. The profusion of bloom is marvelous, over 300 blossoms liaving been counted on one shoot. It is es. sentially a garden rose but makes a magnificent specimen in a pot or tub. There was recently exhibited in Boston a "Crimson Rambler" growing in a 12 -inch pot, the plant being about 4 feet high and 3 feet wide, bearing nearly 5,000 buds and flowers. It is adapted to the entire country, and should be in every garden in America. Price, 2-year plants, $75 \mathrm{c}$ each; potted plants, 1 st size $50 \mathrm{c}$ each; 2nd size, $25 \mathrm{c}$ each.

The Yellow Rambler (Aglaia). After repeated efforts, we have that happy combination of the climbing habit and yellow coloring with a hardiness that warrants its introduction. Rose growers have been striving to secure a rose of this character for years, and the "Yellow Rambler" represents the most complete success yet attained. It has been exposed to a continuous temperature of zero, and even below that, with no protection, thus proving it the hardiest yellow rose known. By laying the plants down in the winter, it can be successfully grown here in the extreme north, and it is well worth the slight effort required to protect it. The flowers are borne in immense clusters, (like the Crimson Rambler), often as many as 150 blossoms in a single bunch. The color is a clear bright yellow in the bud, changing to a beautiful creamy shade when fully expanded. The blossoms have a very agreeable, delicate fragrance and last from three to four weeks without fading. Its vigorous growth (trequently 8 to 10 feet in a season), immense productiveness and wonderful beauty make it a favorite. Price, 2 -year plants, $75 c$ each; potted plants, 1 st size, $50 \mathrm{c}$ each; $2 \mathrm{~d}$ size, $25 \mathrm{c}$ each.

White Rambler (Thalia). This variety, Thalia (the White Rambler), is a fitting companion for the Crinson Rambler, closely resembling it in vine and foliage as well as in the great clusters of pure white flowers, which are deliciously fragrant. The flowers remain on the plant a long time-from three to five weeks-and keep a long time when cut. The plant is perfectly hard $\mathrm{v}$, equal in this respect to the Crimson Rambler, and where one is planted the other should be also. By growing this in a pot and training it to a pyramidal trellis, a fine plant may be had in bloom for Easter. Price, 2-year plants, 75c each; potted plants, 1 st size, $50 \mathrm{c}$ each; 2 d size, $25 \mathrm{c}$ each.

A Combination of the three Ramblers produces the most beautiful effect that can be imagined. The interlacing branches bearing the great pyranidal clusters of red, yellow, and white roses, relieved by the delicate green of the foliage, commands the unbounded admiration of the observer. Price, one each of the three Ramblers, 2-year old, \$2; the same in potted plants, 1st size, $\$ 1.25 ; 2 d$ size, 65 c.

Queen of the Prairie. Bright red, frequently striped ith white.

Baltimore Belle. Pale blush, frequently becoming

Gem of the Prairie. Large, red, fragrant blossoms

occasionally blotched with white.

\section{HYBRID CLIMBING ROSES.}

Jules Margottin. Carmine rose, fine for flowers or buds. May be grown as a climber or pruned to bush form.

Victor Verdier. Beautiful carmine rose color. A vali1able variety.

\section{MOSS ROSES.}

Crested Moss. Fragrant, deep pink colored buds, surrounded with a mossy fringe. Very beautiful.

Princess Adelaide. Medium sized pale roses, of good form. Foliage beautiful but should not be pruned severely.

Perpetual Red Moss. Of a beantiful carmine red color.

Perpetual White Moss. Large, pure white blossoms. Very beautiful.

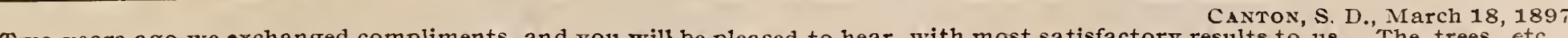

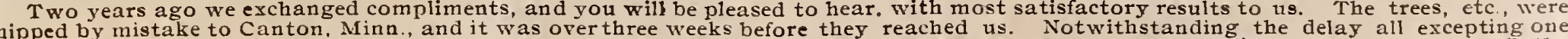

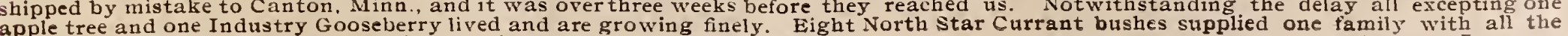
curranta they needed last year. Their growth is wouderful and fruit perfect.

ARTHUR ITNN 


\title{
JUNE ROSES.
}

Madame Plantier. Large, full, pure white blossoms. Free and early blooner. Fine for groups.

Magna Charta. Full, globular, pink blossoms, tinged carmine. Very fragrant and valuable for forcing.

\section{HYBRID PERPETUAL ROSES.}

The following varieties of the Hybrid Perpetual Roses are the best adapted for outdoor culture, and with slight winter protection may be made very successful and satisfactory.

Alfred Colomb, Anne de Diesbach, Fischer Holmes, General Jacqueminot, John Hopper, Mrs. John Laing, Paul Neyron, Victor Verdier. (For description, see pages 31 and 32 .

\section{TREE ROSES.}

\section{Price, \$1.50 each; \$12.00 per dozen.}

No handsomer ornament can be found for the lawn or garden, however small, than the Tree Rose. Standing 3 or more feet high on its hardy stock, every individual bud and biossom can be seen, and, budded with hybrid perpetual Roses, it is a beautiful object the season through. They seem to be exceptionally profuse bloomers, as many as 260 blossoms having been counted on a single bush. They are as easily cared for as are other Roses, requiring, in fact, the same management. During the summer keep the ground rell stirred, not allowing a weed to grow. as the sunlight is fully as needful on the soil as on the foliage of the plants. If the season is dry, water once a week thoroughly at night, and, if possible, shower them. They are easy to lay down and protect in the winter. See engraving made from a photograph of a Tree Rose on our grounds.

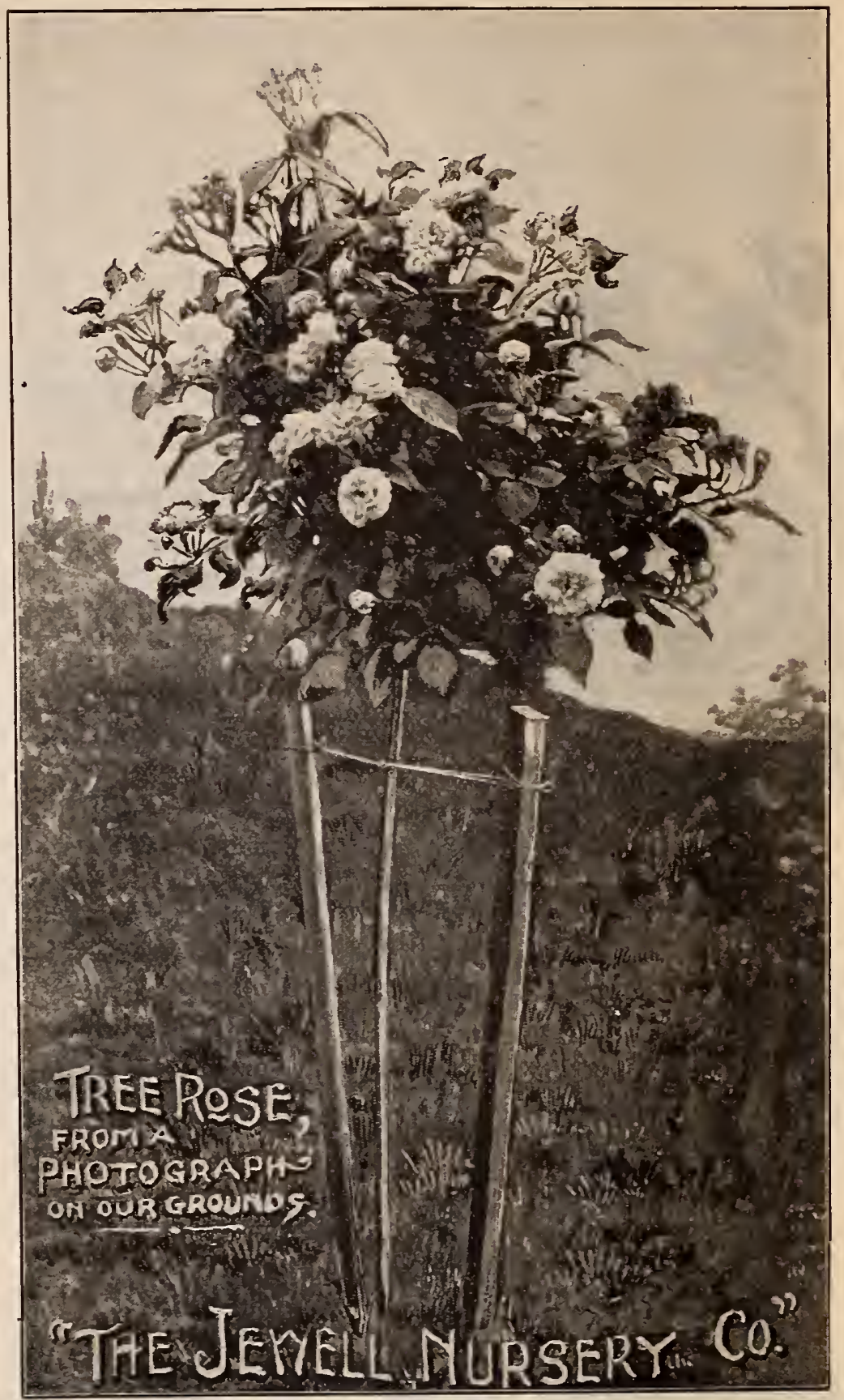

\section{NEW ROSES AND NOVELTIES.}

\begin{abstract}
Varieties priced at 20 c each are $\$ 2.00$ per doz. Varieties priced at $25 \mathrm{c}$ each are $\$ 2.50$ per doz. Varieties priced at $30 \mathrm{c}$ each are $\$ 3.00$ per doz. Varieties priced at $40 \mathrm{c}$ each are $\$ 4.00$ per doz. Varieties priced at $50 \mathrm{c}$ each are $\$ \mathbf{5 . 0 0}$ per doz. Varieties priced at $75 \mathrm{c}$ each are $\$ 7.50$ per doz.
\end{abstract}

The growing demand for the new varieties of Roses, and the general interest in the latest novelties, has induced us to add to our list those that come to us with the best recommendation as to hardiness, beauty and general desirability. Our experience with these is too limited to justify us in recommending all of then as being sufficiently hardy to withstand our climate without winter protection, but we believe, that with reasonable care in the way of a little extra covering, etc., they may be successfully grown here, and become a most valuable addition to our list of outdoor plants. All of them are well adapted to house culture, and may be grown with perfect success in pots for window decoration, with the same care and attention required by our ordinary house plants.

\section{WICHURAINA.}

A low, trailing species, its stems creeping on the earth as closely as ivy, and forming a dense mat of very dark green lustrous foliage. The flowers are produced in greatest profusion, in clusters, after the June roses are past, and continue during the season. They are pure white, the stamens being yellow, from one and one-half to two inches across, and very fragrant, and extremely useful for cutting purposes, especially when in bud. Valuable for covering banks, rockeries, slopes and beds among shrubs. Price, 2-year plants, 60c each; 2d size, $40 \mathrm{c}$ each. 


\section{NEW EVERGREEN HYBRID WICHURAINA.}

W plied as follows: Extra 2-year plants, $75 \mathrm{c}$ each, or the set of 5 for $\$ 3.00 ; 2 \mathrm{~d}$ size plants at $50 \mathrm{c}$ each, or the set of 5 for $\$ 2.00$.

The habit of these new Hybrids is the same as the Wichuraina. The growth is creeping, and can be used with telling effect in covering embankments, terraces, stems of trees, pillars, trellises, or for any other purpose where a strong rapid growing vine is desired. They are the hardiest we grow, and will stand any climate or exposure, and thrive and grow well in the poorest soil, evell on gravel banks. The foliage is particularlybright and attractive, thick and leathery, shining as if varnished, not subject to mildew or insect pests, and keeps fresh and bright until near midwinter. The flowers are very abundant, deliciously fragrant and last in perfection a long time. For forcing as potted plants, these varieties are especially valuable. The growth of these plants is remarkable for its freedom: a single specimen four years old covering a space of 240 square feet, with shoots 12 to 25 feet in length, completely corering the ground with its bright, glossy foliage and showy fragrant flowers. The same plant is making 38 new growths of great strength.

Universal Favorite. A most vigorous grower, with long branching shoots that are covered with dense, bright green shining foliage. The flowers are very double, two inches and over in dianteter, of a beautiful rose color, similar to Bridesmaid; very fragrant.

South Orange Perfection. Similar to the preceding in growth. Remarkably free flowering; when in bloom is a mass of the most perfectly formed double flowers, about one and one-half inches in diameter, soft bluish pink at the tips, changing to white.

Pink Roamer. A hybrid of the Sweet Briar, which it somewhat resembles in character of bloom, while the growth, which is very rampant, partakes more of the Wichuraina type. The single flowers are over two inches in diameter, a bright rich pink, with large silvery white center and orange red stamens, producing a charming effect; delightfully fragrant.

Manda's Triumph. This is the gem of the collection, and may well be called the double "Memorial Rose," as it preserves the color of the parent, with its characteristics of growth and foliage, but the flowers are double and rery fragrant. They are produced in clusters, of from 12 to 18 flowers on each cluster, on small side shoots, literally corering the plant, and standing well above the foliage.

The Hardy Memorial Rose. (Rosa Wichuraina.) For use in cemeteries. It is difficult to conceive anything more appropriate, beautiful and enduring for covering graves and plots in cemeteries than the Hardy Memorial Rose. It creeps along the ground almost as closely as an ivy, growing ten feet in one season and forming a dense mat of very dark green lustrous foliage. The flowers are produced in lavish profusion, in clusters, on the ends of the short side branches, atter the June roses are past, from the first week in July throughout the month, and sparingly for the rest of the season. They are single, pure white, with a golden vellow disc, five to six inches in circumference, and have the strong fragrance of the Banksia Roses. The contrast between the satiny white of the petals and the golden yellow disc, is sharp and pleasing, and is one of the distinctive charms of the beautiful Hardy Memorial Rose, and they fairly cover the entire plant when in bloom, a mass of great snowflakes with the rich, dark green showing here and there. But its use is not confined to cemeteries. Planted in the rose garden, alone or among other roses, and trained upright to a stake, it may be had from three to six feet high, as desired, and it will send sprays of flowers drooping downward, making the prettiest sight imaginable. Trained over a gateway it forms a perfect bower, or it can be trained to a fence or house with equal success. As a pot plant, it is unique and beautiful, in short it is the most useful and unique of all roses. It has been largely used throughout the famous park system of Boston for covering rocky slopes, embankments and such places as it was desirable to corer quickly with verdure. It quickly adapts itself to all conditions of growth, whether barren soil, rocky ledge, fertile garden, shady nook or sun-kissed slope, and no more fitting place can be found for it than running through the grass.

\section{LORD PENZANCE'S HYBRID SWEET BRIARS.}

Rot NoTE.-Lord Penzance Roses will be furnished as follows: Extra 2-year plants at 60 c each, or the set of 5 for $\$ 2.50$; $2 \mathrm{~d}$ size plants at $50 \mathrm{c}$ each, or the set of 5 for $\$ 2.00$.

These constitute an interesting class of perfectly hardy roses, being crosses of the common Sweet Briar with various hardy forms; reproducing the fragrant foliage of the Sweet Briar with the added variety in size, color and profusion of bloom. Flowers single, as large as clematis.

Amy Robsart. Lovely deep rose, an abundant bloomer, robust and free.

Anne of Gierstein. Dark crimson, good grower, and graceful branching habit.

Brenda. Maiden's blush or peach, dainty in color and shade; the contrast and effect of the bright golden anthers add a peculiar charm to this variety.

Lady Penzance. Beautiful soft tint of copper, with a peculiar metallic luster; the base of each petal is a bright yellow, which, showing through the clear golden anthers, forms a halo around them; very free flowering, with a delicious perfume from foliage and flower.

Megg Merrilies. Gorgeous crimson, very free flowering, seeds abundantly, lias a wonderfully robust habit, large foliage; one of tlie best.

\section{A NEW CLIMBING ROSE.}

Empress of China. This new rose was brouglit out only a short tinie since by one of the most prominent Eastern Rosarians, who describes it as follows: "A rampant climber, collmencing to bloom in early summer, and continuing until laard frost, with flowers of medium size, sen1i-double, deep red in the bud, changing to pink and red in opening, and a charming fragrance. Fine for covering trellises." Strong 2-year plants, 7.5c each; 2d size, $50 \mathrm{c}$ each.

\section{ROSA RUGOSA.}

\section{Strong 2-year plants at $60 \mathrm{c}$ each; 2 d size at $50 \mathrm{c}$ each.}

We hare tloroughly tested this nost interesting group of Japan roses onl our grounds for the past five years, and can recommend then without hesitation, as being perfectly hardy and rrell adapted to outdoor culture in Minnesota. The foliage is the most beautiful of any of the rose family; while its large, handsome scarlet fruit gives it an added beauty all through the autumn and early winter months. It forms a sturdy bush 4 to .j feet high, covered with large, dark green glossy foliage, crowned with terminal clusters of 10 to 20 flowers two to three inches in diameter. A inost valuable plant for hardy borders and shrubberies.

Rosa Rugosa Alba. The white flowered variety, with single, pure white blossonis of fire petals. Highly fragrant and a splendir shruh.

Rugosa Rubra. Flowers single. Most beautiful bright rosy crinison, succeeded by large berries of orange red color.

By planting alternately the red and white, a most pleasing and striking effect is produced.
"O, fondest object of my care,

Still fairest found, where all are fair

For the sweet shade thou giv'st me

Ask what thou wilt; 'tis granted thee.

Then said the rose, with deepened glow,

On nie another grace bestow

The spirit paused in silent thought, -

What grace was there that flower had not

'Twas but a moment,-o'er the rose

$A$ veil of moss the angel throw's,

And, robed in nature's simplest reed.

Could there a flower that rose exceed ". 

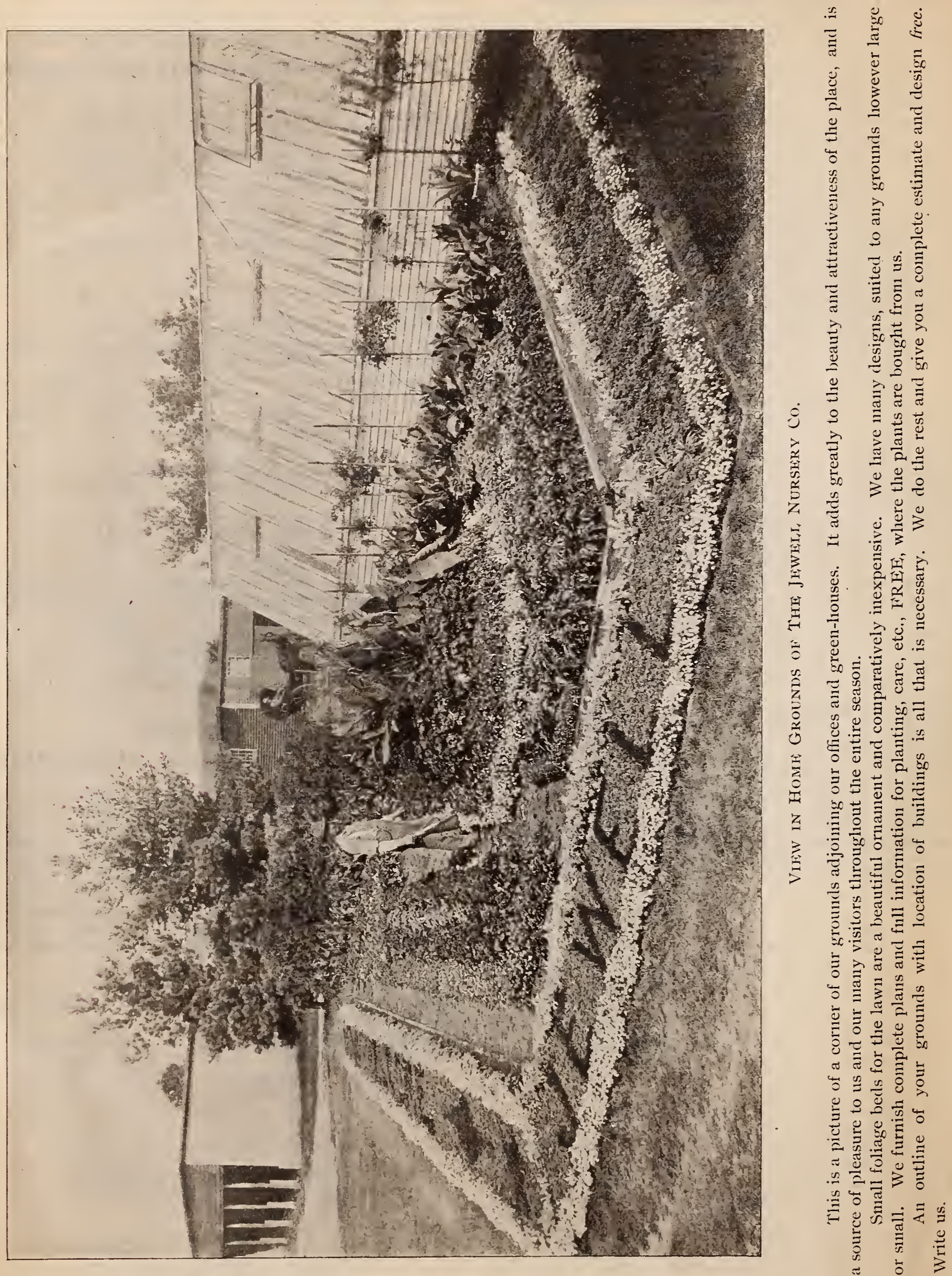
Sibley, Iowa, May 24, 1897-I am well pleased with the stock you sent me.

J. FRED MATtert.

Beresford, S. D., May 13, 1897.

Plants received in good condition. Was very much pleased with tlie size and quality.

J. R. CARLSTON.

Houston, Minn., March 23, 1897.

Had several dollars' worth of goods of you last season, and am well satisfied with what you sent.

C. P. Schonlau.

Thief River Falls, Minn., May 18, 1896.

Goods came in good condition and were satisfactory in every way. Everyone who saw them said they were very nice.

jOHN MOYLAN.

(From a Pioneer Horticulturist, Chairman Exec. Com. etc.) La Crescent, Minn., 1894.

The Okabena is all rlght, and I believe it is destined to reflect credit upon the introducers.

J. S. HARRIS.

Noxon, Mont., Sept. 25, 1897.

I want to get a lot more of your trees as soon as I can. Some of the trees I got of you last fall have made a growth of over three feet this summer. They are very thrifty and the bark is almost black.

A. C. Nottingfas.

Alexandria, S. D., May 14, 1897.

Yours at hand, also the roots to replace those of the former order that did not grow. I certainly have reason to thank you for your fairness in this matter, and I shall do all I can to make the new roots grow.

V. K. STILLWELL.

Alexandria, Minn.

The plants came to hand in due season. I want to again com. pliment you on their good condition and fine roots. I have been buying plants for over twenty-five years, and have never received a better lot, if as good, as those from you. JOHN PRITchetT.

Winthrop, Minn., July 13, 1897.

I enclose a check herewith for $\$ 7$ on my account. I have mislaid the copy of the order so I cannot say if this amount is correct, but if you will please look it up I will remit balance. The nursery stock I receired was first-class and everything is growing. P. P. QUIST.

Good Thunder, Minn., April 18, 1898.

I have just made the delivery at Good Thunder. The stock was in fine shape and gave splendid satisfaction. They are without doubt the finest stock I ever delivered.

D. ALTAY.

(This letter is from one of our agents just after making his first delivery of our goods.)

Eagle Grore, Iowa, May 7, 1897.

Enclosed please find draft for $\$ 147.75$, and your Mr. Carder's receipt for $\$ 20$, same being payment in full of trees purchased of you by the Eagle Grove park commissioners, and will add that the park commissioners are highly pleased with the trees furnished by you, and with the treatment received at your hands.

\section{A. N. OLDENHEIMER,}

Sec. Park Commissioners.

\section{BOARD OF PARK COMMISSTONERS,}

City of Dultuth, Oct. 31, 1898 .

All of your stock of whatever sort that has come here, has made a successful and satisfactory growth, so far as I have had opportunity to be acquainted with and to observe. I believe this locality is as well adapted to fruits that succeed in Minnesota, as any place in the state. I feel so sure of it that I am anxious to try the experiment as soon as possible, and when I do you will doubtless hear from me.

H. C. HELM, Sec'y and Supt.

Fredonia, N. Y., Oct. 1, 1897.

Your kind letter received. I wrote you some time ago that I wanted to tell you about the North Star Currants I saw at Mr. E. B. Lewis', at Lock Port, N. Y., just as the fruit was ripening. There were 100 of the bunches, and I never saw such a sight in currants before, Every bush was loaded to its full capacity, and they were so uniform that the fruit on one bush was almost identical with all the rest. I never before in my life saw so much fruit on one hundred plants, and it was of fairly good size.
Lake Crystal, Minn., May 24, 1897. The trees came in first-class condition and were satisfactory in every respect.

G. W. HOLMES.

Austin Cemetery Association,

Austin, Minn, Jan. 12, 1899.

The trees bought of you for our cemetery during the past two or three years, have nearly all lired. We shall want more this spring.

D. H. Stimson, President.

Langdon, N. D., Oct. 6, 1898.

The roses sent me grew orer two feet and several blossomed. Many people have admired them. They thought roses would not grow in this country, but I have proved the contrary.

S. G. Gibson, M. D.

Lan caster, $\mathrm{Pa}$

I got two plants of the North Star Currant in the fall of 1891 , and I find it is an immense bearer, good size and of best quality. Am sorry that I did not get more of them at that time.

DANIEL D. HERR, Nurseryman.

Prospect Hill.

The new currant, the North Star, is a good grower, great bearer and of good quality, and hangs on to the plants a long time after being thoroughly ripe. Were I to grow currants for market I should plant this variety in preference to any other.

WM. ALLBN.

Minneapolis, Minn.

The North Star Currants I got of you last spring have adapted themselves nicely to this locality. They have done better than I even expected they would the first season, being planted late in the spring. Quite a number of berries of a superior quality this season. By all appearances it will prove first-class.

JACOB BARGE.

Duluth, Minn.

The plants I got from you last spring are doing splendidly. Out of fifty plants, more than half of them roses, only one (heliotrope) died. Thefuchsias are the finest $I$ have seen. One that was three inches high in May had, one day in August, over 30 buds and blossoms, and it is blossoming yet.

\author{
A. B. LANGE, Editor and Publisher.
}

(From one of the oldest Horticulturists in Minnesota.) Viola, Minn., May, 1894.

The trees I ordered were in good condition. I desire to express my appreciation of the Thompson Seedlings, N. W. Greening and Okabena. Haring seen the original Okabena apple tree, I consider it the most perfect seedling in the State of Minnesota. Three years ago I got of you two Okabenas and three Thompson Seedlings, and set them in a young orchard of fifty varieties, and they have made a fine growth.

WM. SOMERVILLE.

\section{(From the extreme North.)}

Oscar Lake, Minn., Oct., 1895.

I bought of the Jewell Nursery Co.in 1887, $25 \mathrm{M}$ artha and 25 Minnesota, and I have now 48 live trees, which have borne fruit for me since 1890. I then bought 50 more apple trees. All of them are bearing, but I think the most of my Okabena and Hibernal, as I have taken first premium twice at our county fair. The Hibernal is a larger apple, but the Okabena apple is much better in quality. I advise all to give the Okabena and Hibernal apple trees a trial.

\section{PETER UNUMB.}

(T. C. Kevitt, Prospect Hill Nurseries, Athenia, N. J.)

Our fruit growers are getting a chance at last to secure the best currant on earth-the North Star. Our sales of the North Star last spring were indeed remarkable, and it would serve to show that growers want the best. Your services as the originators of the North Star can best be appreciated by imagining the commonwealth without this exquisite fruit. We hare noted on our grounds the excellence of the berry, the large size and compactness of the bunches and the vigor of the plants.

Pin Oak, Iowa, Jan 25, 1898.

The nursery stock $I$ bought of your agent last year was delirered last April in a good and thrifty condition, and hare all grown splendidly. I have now been growing nursery stock for forty years, and have found yours the best I have ever planted, and have now taken another order from your agent. All my neighbors who bought of your agent are as well pleased as I am, and I must say that the only trees that do good here must be grown in the North, and they will grow well and bear abundantly. 


\section{TESTIMONIALS.}

Watertown, S. D. March 8,1897 . I had splendid success with stuff bought of you last season.

S. A. BRIGGS.

Huron, S. D., A pril 29, 1897.

I am pleased with the trees and shrubs I received from you.

JOHN LONGSTAFF. finc.

Eureka, Minn, May $10,1897 .-T h e$ quality of the plants sent is

Eagle Grove, Iowa, March 20, 1897.

I bought a small bill of goods of you last year and they proved satisfactory.

V. M. Sirith.

Eagle Grove, Iowa. March 18, 1897.

I dealt with you last year and am well pleased. You did more than you agreed. Thanks.

F. A. GAtes.

West Union, Iowa, April 24, 1897.

The Plums, North Star Currants and Downing Gooseberries came in nice shape, and I must say they areall very, very fine. Many thanks.

J. F. SuITH.

The stock has arrived in fine form. It was taken from the depot the day of its arrival and the following morning was carefully heeled in. The stock arrived in good shape, and seems to be in very fine form.

O. C. GREGG.

. Williamsburg, Iowa.

The trees I received from you were the finest I ever received from any nursery. The stock was all alive, thrifty and vigorous. I heartily recommend your Northern.grown trees, and advise my neighbors to get their supply from you.

JOHN J. YATES.

Columbus, Neb., May 8, 1897.

The package of North Star Currants came duly to hand and in fine condition. For size and quality of bushes I never saw their equal. I let $m y$ friends have some of them and they were all rery much pleased. Accept my thanks for good plants and good packing.

Dood packing.

Northwood, Iowa, May 8,1897

The trees you sent me were received to-day, and I am very much pleased to get so many and such excellent trees. It is more than could expect, and I want to thank you for the favor. I may need more trees next season and will order them from you, and shall also recommend you to others who may want trees.

GILBERT J. THOMPSON.

EXPERIMENTAL STATION,

St. Anthony Park, Minn., May 31, 1897.

Yours of the 27 th and plums sent under a separate cover noted I am much pleased with the fruit and tree of your Aitkin plum, as both are very distinct. The fruit is particularly large and high colored. The tree is an early and healthy bearer, and very hardy. It is the most promising thing in the plum line for this section that $\mathrm{I}$ have seen for many years.

SAMUEL B. GREEN.

Bozeman, Mont., July $3,1897$.

Mrs. Yerkes received her rubber plant to-day, and to say that she is delighted would be mild. Our experience, and that of others in this valley, has been so widely different from the treatment we have received at your hands that it is a matter of something more than favorable comment on the part of ourselves and friends. In view of this I take the liberty of writing you our thanks and stand ready to recommend you to our friends.

A. K. YERKES, Editor Chronicle.

Bijou Hills, S. D. A ug. 4, 1897.

Four years ago we gave you quite an order for fruit trees, and I will say they were the finest lot of fruit trees I ever saw sent from any nursery. Out of one hundred and one we have lost but eleven trees in four years. One lot of four trees hadeither lost its label or was not labeled at all, and $m y$ object in writing is to, if possible, find the name of these trees. They were two years old when we set them and have now fruited three years. They are small trees yet, but one one has forty-one fine apples on now. I will send you fruit and leaves and I suppose yot can send me name of variety. Please send me catalogue for' 97 and '98. Think I will sell some stock for you, as I can from cxperience heartily recommend your trees.

J. H. KENDALL.
Oliria, Minn., May 25, 1897.

The quality of stock and prices were very satisfactory indeed. J. E. W. PвtERSON.

Hillsboro, N. D., July 6, 1897.

Stock was all I expected or could ask, and has given entire satisfaction. You will hear from me later. E. S. KNEELAND.

Aberdeen, S. D., March 19, 1897.

The apple trees that I got of you a couple of years ago for my farm at St. Charles, Minn., are doing splendidly. J. G. ZMMMERMAN.

Ouray, Col., May 4, 1897 .

I received the 100 North Star Currants two days since. They are fine large plants, and have good roots.

R. H. Higgins.

Ridgeway, Iowa, March 17, 1897.

I gave you an order last year for apple trees to the amount of $\$ 17.50$. I am satisfied with the order. The trees all did well. JOHN L. WEMARK.

Lake Mills, Iowa, Nov. 16, 1898.

The trees I planted last spring did splendidly last summer. Not one died. I shall see my neighbors, as I think of getting some more trees myself, and if I could get some more orders besides, I should like it O. N. ROALKYAM.

Andover, S. D.. June 24, 1897.

The fruit trees and North Star Currants I bought of you last year are as fine and handsome as one could ask. Several parties have spoken to me for more fruit trees and I want more myself this fall, and will make a regular business of taking orders for fall delivery.

W. H. SEXTON.

Mineral Point, Wis.

I received the stock I ordered, and I am so well pleased with the trees and your courteous treatment that I feei it my duty to acknowledge the same. I have bought over $\$ 300$ worth of nursery stock in the past two years and that I got from you is the best I ever saw.

JAMES PRINCE.

Edgemont, S. D., October 20, 1897.

The plants I ordered of you arrived yesterday, and they were far beyond my expectations, as the stock delivered hy other parties who have canvassed here was not as represented. These plants are of good size and all look healthy, and I thank you for the fine stock you sent me.

IV. CARPENTER.

Lyle, Minn.

Some years ago I got iny first lot of trees from you, and they are elegant. We had one tree that we had to prop up for fear the limbs would not be able to carry the fruit. On twigs one-half inch through we have counted seventy-two apples. In writing this I only give your trees credit for what they are. $\quad$ L. M. RAWN.

Missoula, Mont., May 19, 1898.

Your shipment of Shrubbery, etc., came a short time since and we were very agreeably surprised at their excellent condition. Everything was as fresh and bright as though just taken from the ground. Please accept our thanks for your kindness and liberality in dealing with us. We shall not omit an opportunity to speak a good word for you. THOS. P. STREET.

\section{(Pukwana Press.)}

There is a great deal of comfort in doing business with business men, and this term can be applied to the gentlemen conducting the Jewell Nursery at Lake City, Minn. Publishers will find in this firm a promptness which is seldom experienced from foreign adrertisers. The Jewell Nursery Company are comparatively small advertisers. but that cuts no figure. They will probably increase this method of gaining publicity as the firm sees the benefit. But the point we were going to get at is this: When your bill reaches the office of that firm it is promptly paid. It is not necessary to send them two or three bills, write half a dozen letters, and wait six months for the money due the publisher. Monday morning of last week this office sent bills to several foreign advertisers. On Wednesday night we received a draft from the Jewell company, and this is not the first time this company has shown such promptness. The parment of bills sent to the other advertisers is still forthcoming. When you need any seeds, trees, or in fact anything kept by nurseries, write the Jewell Nursery Co., Lake City, Minn. They will be sure to please you. 


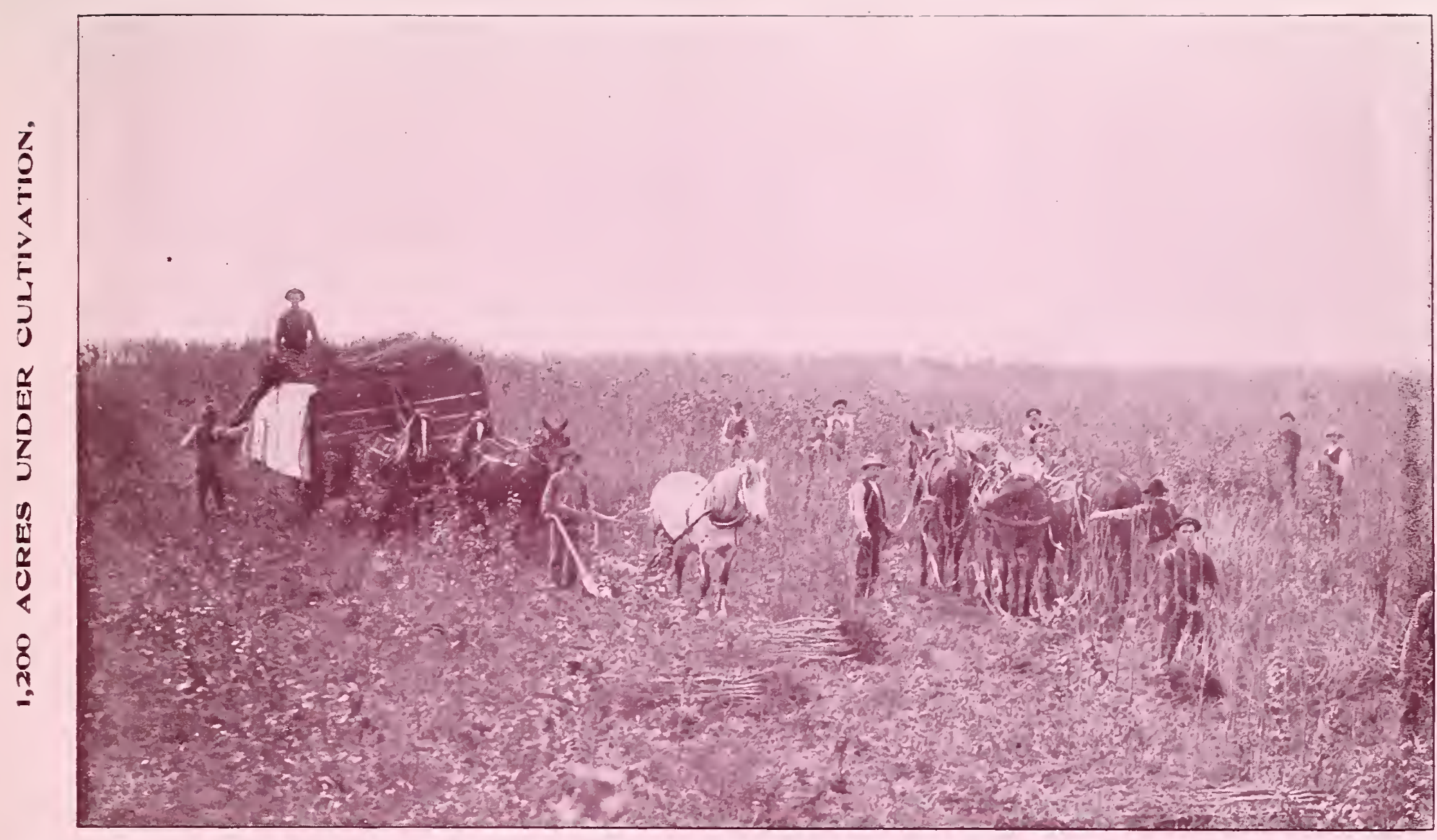

A Scene in our Lake City Nurseries, the Home of the Obabena and Aitkin. The Digging Crew at Work on a 20 Acre Field of Hardy Apple Trees.

\section{INDEX.}

\begin{tabular}{|c|c|c|c|c|c|}
\hline & & & & & PAGI \\
\hline bies (Spruce).... & Day I.ily ......................... & 20 & Lychnis ....... & Scotch & \\
\hline cacia (I ocust) & Lelphinium (Larkspur) & 21 & Lysimachia.... & Sheepberry.. & 31 \\
\hline$(\mathrm{M}$ a ple $) \ldots \ldots \ldots \ldots \ldots \ldots \ldots$ & Deutzia........................... & 18 & & & \\
\hline Achillea .................... 22 & Dewberries.... & 14 & Maple........................ & smoke Tree... & 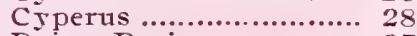 \\
\hline Aitkin $($ Plum $) \ldots \ldots \ldots .8,9,10$ & Dicentra ................... & 20 & Matrimony Vine . ......... & Snowball.................. & Daisy, Paris .................. \\
\hline Almond (Flowering)..... is & Uiervilla ( Weigelia) ...... & 19 & Meadow sweet.........19, 22 & Solidago (Golden Rod).. & Easter Lily........ \\
\hline Ampelopsis $(\operatorname{I} \vee y) \ldots \ldots \ldots \ldots$...... 19 & Dogwood .................. & 18 & Milfoil ..................... 22 & Spiræa.............19, 21, 22 & 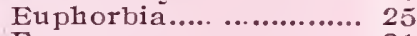 \\
\hline Anemone................... 22 & Dutchman's Pipe............ & 20 & Moccasin Flower.......... & & 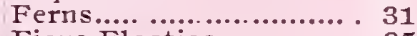 \\
\hline Apples.....................5, 6,7 & Elder ................................. & 18 & Mock Orange ................. & Spruce $. . . \ldots \ldots \ldots \ldots \ldots \ldots \ldots . . . . . . .$. & Ficus Elastica.......... \\
\hline & Elm $\ldots \ldots \ldots \ldots \ldots \ldots \ldots$............. & 16 & Money wort...................... & starwort (Aster)........... & Freesias.................... \\
\hline Aquilegia (Columbine).. 20 & Eulalia ........................... & 20 & Mountain Ash.......... & Straw berries ................... & Fuchsias................ \\
\hline & 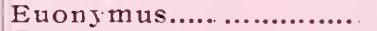 & 19 & Mountain Pine......... & Strawberry or Spindle & Genista Racemosa... \\
\hline Aristolochia .................. 20 & Evergreens .... & 17 & Mulberry.................. & 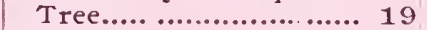 & Geraniums... \\
\hline Arrow Root...... & Facilities ...................... & 1 & Norway spruce............ & Sumach ................... & awberry.. 26 \\
\hline .............. 22 & Feverfew (Pyrethrum).. & $2 \overrightarrow{1}$ & Number Trees per Acre.. & & \\
\hline Ash...................... 15, 16 & Flowering Almond........ & 18 & 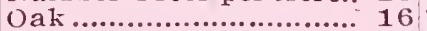 & Tan & Gloxinia.............. \\
\hline Asparagus................ 14 & Forsythia................... & 18 & Okabena...................... & rian Honeysuckle & len Glow........ \\
\hline …................. 20 & Fraxinus (Ash) .......... & 15 & Olive...................... 16 & Tecoma.......... & 26 \\
\hline 21 & Funkia .................. & 22) & Ornamental Department & Tho & $\mathrm{Hi}$ \\
\hline Gilead ................... & ardia... & 21 & ............15 to 24 & 18 & Hya \\
\hline 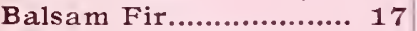 & niums.. & 20 & tal Shrubs....... 18 & Thuya (Arbor Vitæ) & Hydrang \\
\hline ry or Berberry ... & & 16 & gge.............. & $T=0$ & 31 \\
\hline od .................. 15 & Gla & 23 & 22 & 15 & Gracillis.... \\
\hline Bedding Plants ............. & Golden Bell... & 18 & Papaver (Poppy)... & Timber Claim Seedlings & nas.......... \\
\hline Bell Flower ................... 20 & n Glow.. & 21 & 11 & pet Vine ................ & n Verber \\
\hline ch (Betula)..........15, 16 & Golden $\operatorname{kod} . .$. & 21 & 10 & Ulmus $(E / m) \ldots \ldots \ldots \ldots 15,16$ & Li] \\
\hline 20 & erries... & 12 & A pple & .......... 19 & $\mathrm{Ma}$ \\
\hline 14 & ...............11, & 12 & $11 \mathrm{Pea}$. & ...........19, 20, 31 & Mo \\
\hline Heart.......... & Plants 24 to & 28 & elphus. & מia Creеper........... 19 & My \\
\hline 19 & dus ................ & 15 & Phlo & 16 & $\mathrm{Na}$ \\
\hline Elder...................... & ila & 20 & Pine (Pinus) & mental Trees... & Ota \\
\hline kthorn ..................... & .............. & 15 & Pinks.. & 19 & $O:$ \\
\hline Buffalo Berry ................ & $\mathrm{Ha}$ & 20 & 22 & 16 & $\mathrm{~Pa}$ \\
\hline Business Details ............. & ck............................ & 17 & Flowering........... & White Pine ............. & $\mathrm{Pa}$ \\
\hline Buttercup.................... & us Plants 20.21 & 22 & (................. 8,9 & Sorian & Par \\
\hline 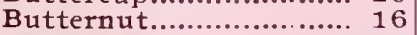 & a vilily) & 20 & (Populus) .......... & 20 & Passion Flower... \\
\hline Campanula ................... & sh Cranberry & 19 & 21 & Woodbine............... & Prir \\
\hline inus ................... & ........19, & 20 & Prin & Yarrow ................... & Potho \\
\hline Castanea (Chestuut)..... & .................. & 15 & Primula. & & . Climbing \\
\hline talpa ............................ & ut $\ldots . . . \ldots \ldots$ & 15 & 18 & GREE & $\mathrm{Rc}$ \\
\hline Celastrus Scandens ..... & ea..................... & 18 & Purple Fringe................ & END BULBS. & Roses. June.................. \\
\hline Chalk Plant................. & & 21 & Pyrethrum (Feverfew).. & & Roses, Moss .................. \\
\hline Cherries ...................... & & 19 & $(\mathrm{Oak}) \ldots . . . . . . .$. & Abutilo & Roses, Ru \\
\hline Chestnut ................... & Juglans (Walnut).. & 16 & 20 & Allium Neapolitan... & Roses, Sweet Briar... \\
\hline 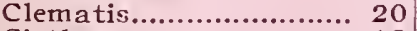 & & 14 & 14 & & Ro \\
\hline ara...................... 18 & or Juniperus...... & 17 & Red C & 31 & . Tre \\
\hline ag Vines....19, 20, 31 & 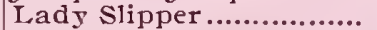 & 21 & (Buckthorn). & 28 & Roses, wichuraina.....34, \\
\hline ee Tree.................. 15 & Flower............... & 21 & (n........................ & & Rubber Plant \\
\hline mbine.................20 & & 21 & 19 & & Elastica) .......... \\
\hline & & 15 & 18 & & Salvia Splendens........... \\
\hline od )...15, 18 & yrus.. & 21 & Ribbon Gra & & Star of Bethlehem........ \\
\hline & & 18 & $\ldots 31$ to 35 & & sonia Alba............ \\
\hline Cowslip ..................... 22 & Linden (Basswood )..... & 15 & 21 & & trose \\
\hline Cranberry ...... & Lilies (Lilium) .............. & 23 & & & \\
\hline Crane's Bill ................. 20 & Location, Planting and & &. .16 & Cannas. & Umbrella Plant... \\
\hline Currant Flowering ...... 18 & & & & & \\
\hline rrants................... 13 & Loc & $1 \overline{5}$ & s (Elder) ......... & & Ver \\
\hline ...... 21 & suckle) & 19 & Shade a & & \\
\hline & & & & & \\
\hline
\end{tabular}




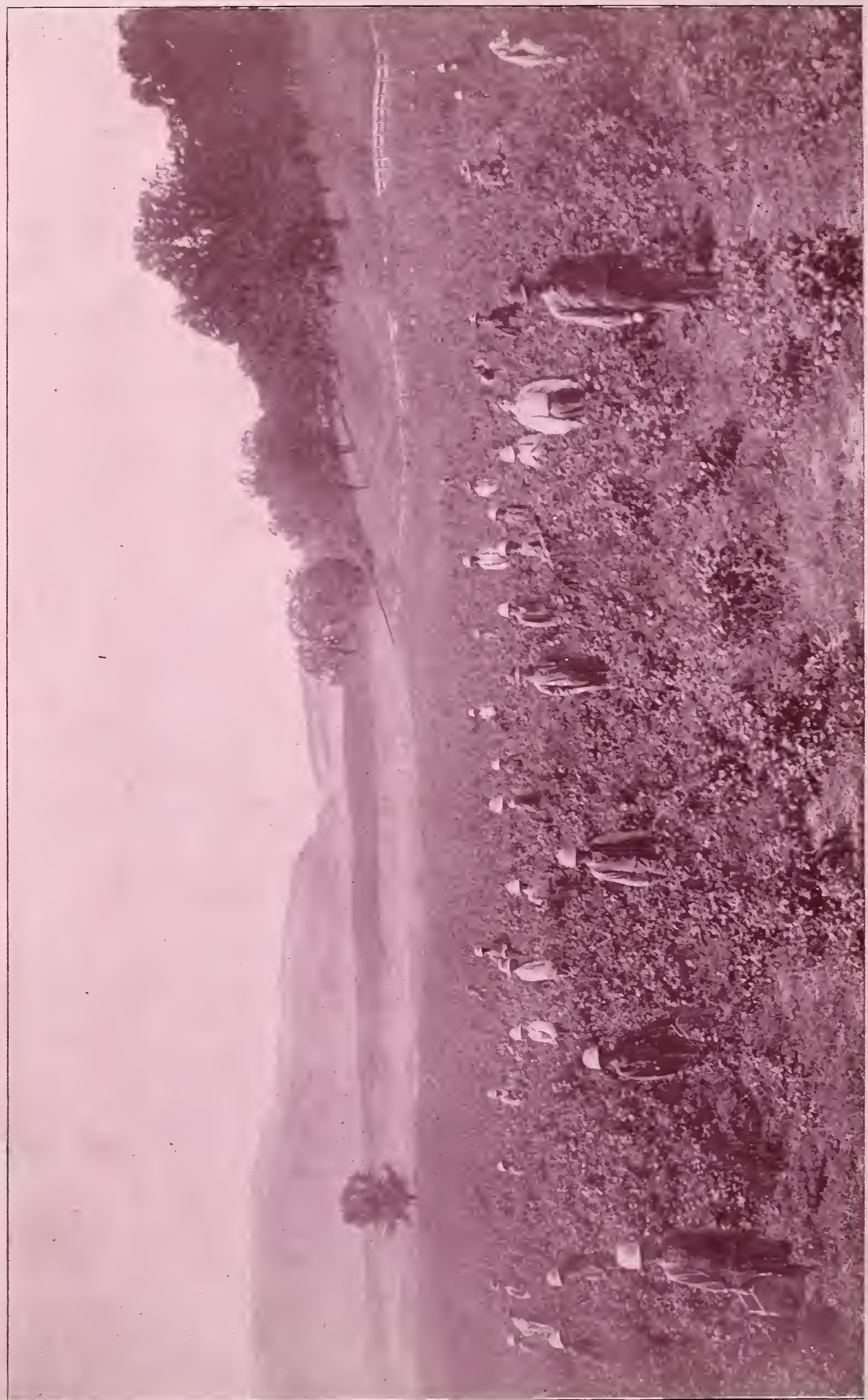

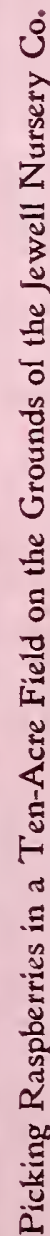

